\title{
EFFECT OF ANTIMICROBIALS AND SODIUM REPLACEMENT AGENTS ON THE SURVIVAL OF PATHOGENIC BACTERIA IN LOW SODIUM LOW-MOISTURE PART-SKIM (LMPS) \\ MOZZARELLA CHEESE
}

\author{
A Thesis \\ presented to \\ the Faculty of California Polytechnic State University, \\ San Luis Obispo
}

\author{
In Partial Fulfillment \\ Of the Requirements for the Degree \\ Master of Science in Agriculture, with a Specialization in: \\ Food Science and Nutrition \\ by \\ Tiffany M. J. Taylor \\ December 2013
}


(C) 2013

Tiffany M. J. Taylor

ALL RIGHTS RESERVED 


\section{COMMITTEE MEMBERSHIP}

TITLE:

Effect of antimicrobials and sodium replacement agents on the survival of pathogenic bacteria in low sodium low-moisture part-skim (LMPS) mozzarella cheese

AUTHOR:

DATE SUBMITTED:

COMMITTEE CHAIR:

COMMITTEE MEMBER:

Amy Lammert, Ph.D.

Assistant Professor

Food Science and Nutrition

COMMITTEE MEMBER: Nana Farkye, Ph.D.

Professor

Dairy Products Technology Center 


\author{
ABSTRACT \\ Effect of Antimicrobials and Sodium Replacement Agents on \\ the Survival of Pathogenic Bacteria in Low Sodium \\ Low-Moisture Part-Skim (LMPS) \\ Mozzarella Cheese
}

Tiffany M. J. Taylor

Recent increases in chronic cardiovascular diseases, such as hypertension, have put pressure on the food industry to reduce sodium levels. Dairy products, though full of vital nutrients, are perceived as being high in sodium. However, the reduction of salt in dairy products could potentially alter the microbial stability, as well as cause unfavorable changes in flavor. In order to reduce the sodium level, while maintaining acceptable flavor and microbial stability, salt replacers and alternative antimicrobial agents may need to be introduced into the food matrix. To identify potential antimicrobials for use in reduced sodium dairy products, this study evaluated the efficacy of eight commercially available antimicrobials in TSA, milk agar, and cheese agar. Antimicrobials included MicroGard 100, MicroGard 430, Nisaplin, NovaGard CB1, Protect-M, PuraQ Verdad RV75, SEA-i F75 and VMY1P. Antimicrobials were also tested in combination with six commercial sodium reduction agents (potassium chloride, Puracal PP/USP, Purasal Hi Pure P Plus, PuraQ Verdad 
NV10, SaltWise 0029 and SaltWise 1029) to if there were any interference with antimicrobial activity.

Antimicrobials with and without sodium reduction agents were added to the agar systems, then a five-strain cocktail of Listeria monocytogenes, Salmonella or Escherichia coli $\mathrm{O} 157: \mathrm{H} 7$ was spread plated at three concentrations: $10^{1}, 10^{2}$ and $10^{4} \mathrm{CFU} /$ plate. Samples were then incubated at $35^{\circ} \mathrm{C}$ and observed for growth after 24 and $48 \mathrm{~h}$. SEA-i F75 was the most effective antimicrobial in each of the agars tested. Additionally, no interactions were observed between SEA-i F75 and any of the sodium replacement agents.

SEA-i F75 was selected for use in a final challenge study using six formulations of LMPS mozzarella cheese: regular sodium control cheese $(1.7 \%$ $\mathrm{NaCl}$, no antimicrobial added); low sodium control cheese $(0.7 \% \mathrm{NaCl}$, no antimicrobial added); low sodium treated cheese $(0.7 \% \mathrm{NaCl}$, treatment with SEA-i F75); low sodium cheese with $\mathrm{KCl}$ as salt replacer $(0.7 \% \mathrm{NaCl}, 1.0 \% \mathrm{KCl}$, treatment with SEA-i F75); low sodium cheese with Alta 2345 as salt replacer $(0.7 \% \mathrm{NaCl}, 0.25 \%$ Alta 2345 , treatment with SEA-i F75); and low sodium cheese with Salona as salt replacer $(0.7 \% \mathrm{NaCl}, 0.95 \%$ Salona, treatment with SEA-i F75).

Fifteen gram cheese pieces from each formulation were dipped in an antimicrobial solution containing $0.25 \%$ SEA-i F75 then inoculated with $L$. monocytogenes, Salmonella, or E. coli $\mathrm{O} 157: \mathrm{H} 7$ at a target inoculum concentration of $10^{2}-10^{3} \mathrm{CFU} / \mathrm{g}$ and incubated at either $4^{\circ}$ or $12^{\circ} \mathrm{C}$. In all trials, over all formulations and temperatures tested, initial decreases in counts, 
followed by organism recovery were observed. Therefore, SEA-i F75 was not effective at reducing the counts of pathogenic bacteria in LMPS mozzarella cheese.

Results from this study highlight the effect of the food matrix, and its components on antimicrobial efficacy. Future research includes examining the effect of one of the other antimicrobials in LMPS mozzarella cheese. 


\section{ACKNOWLEDGMENTS}

I would like to thank my committee-Dr. Amanda Lathrop, Dr. Amy Lammert and Dr. Nana Farkye-for their support and guidance throughout my graduate school experience. Through them, I have gained valuable knowledge, helping me to grow as a person and a scientist.

I would also like to thank Andrew Kok, Toni de Senna, Jessica Ryugo and Adam Yee for their extensive help with setting up experiments and processing samples. I would have never finished the work without their help and, for that, I am eternally grateful.

I am very thankful for the financial support provided by the Dairy Research Institute (DRI).

Finally, I am incredibly grateful for the love, support and encouragement from my family, my friends and my Lord, Jesus Christ. 


\section{TABLE OF CONTENTS}

List of Tables ............................................................................................ xii

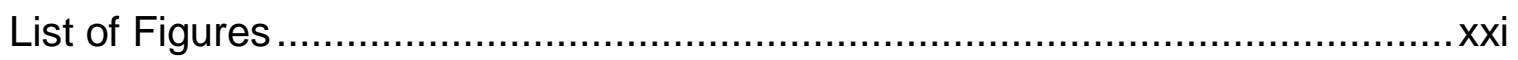

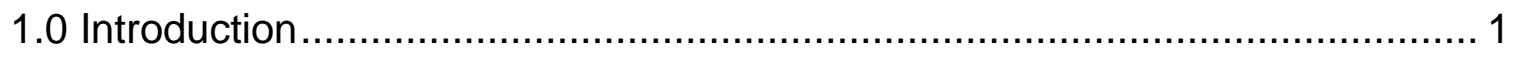

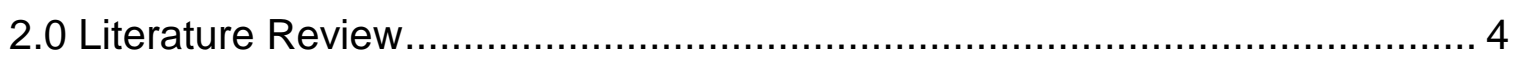

2.1 Low-Moisture Part Skim Mozzarella Cheese ............................................ 4

2.1.1 Cheese Consumption in the US .................................................. 4

2.1.2 Cheese Manufacture and Composition ............................................ 4

2.1.3 Consumer Health Concerns with Cheese Products ........................... 7

2.2 Salt Reduction Challenges …...................................................... 9

2.2.1 Importance of Salt in Cheese ................................................... 9

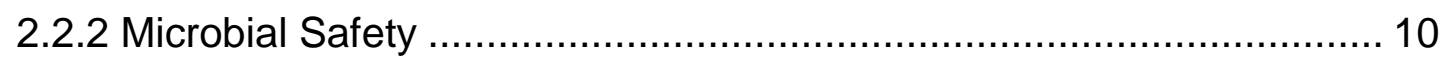

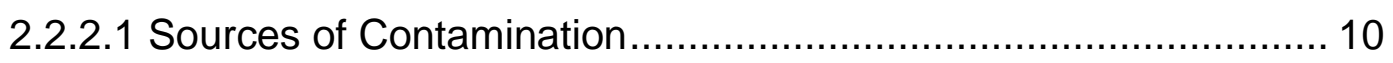

2.2.2.1.1 Unpasteurized Cheese Products ...................................... 10

2.2.2.1.2 Recontamination of Cheese Products .............................. 11

2.2.2.2 Pathogen Growth and Survival in Cheese ............................... 13

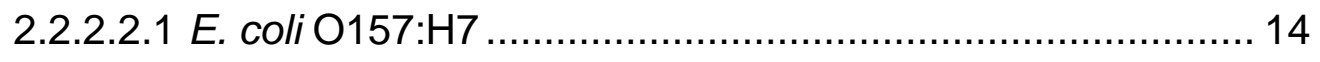

2.2.2.2.2 Salmonella spp....................................................... 15

2.2.2.2.3 Staphylococcus aureus ................................................ 16

2.2.2.2.4 Listeria monocytogenes .............................................. 17

2.2.2.3 Cheese-Related Outbreaks .................................................. 19

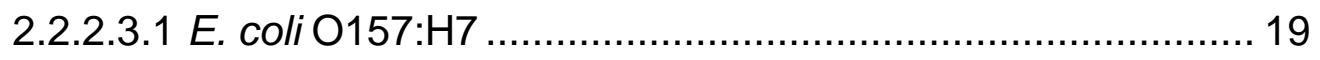

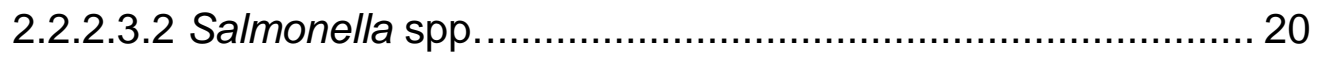




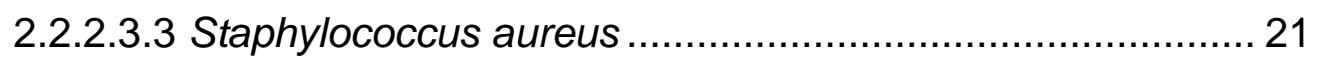

2.2.2.3.4 Listeria monocytogenes ............................................... 22

2.3 Formulating Reduced Salt Products ...................................................... 23

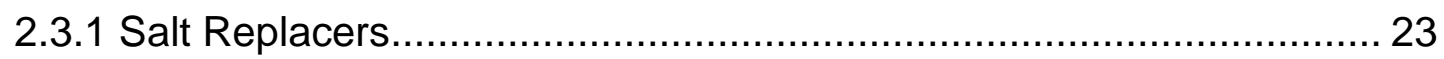

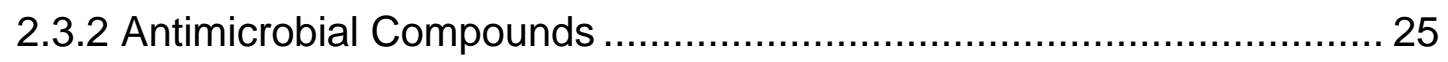

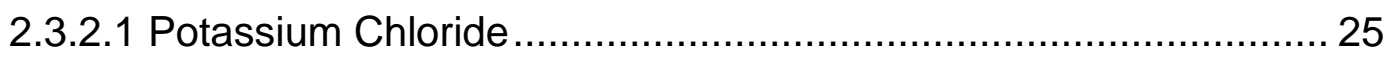

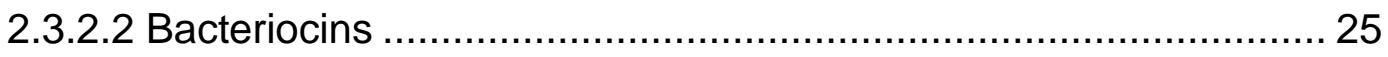

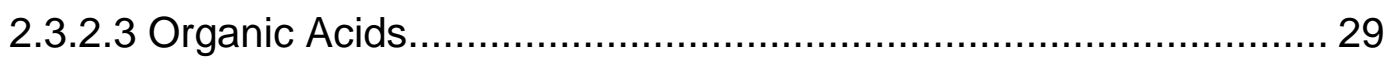

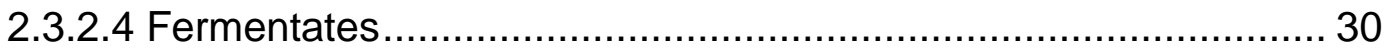

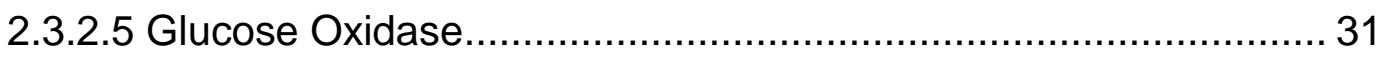

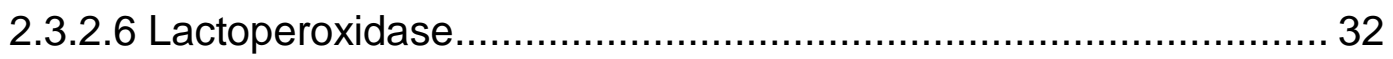

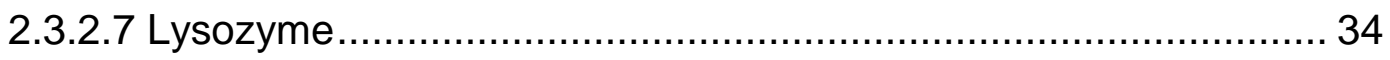

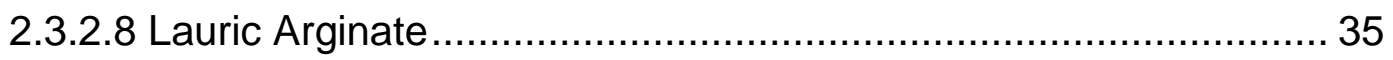

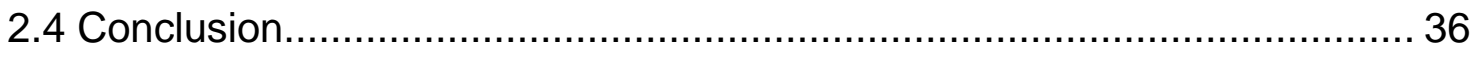

3.0 Antimicrobial Efficacy Screening in TSA ................................................. 37

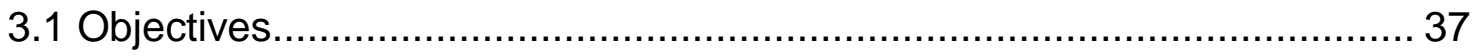

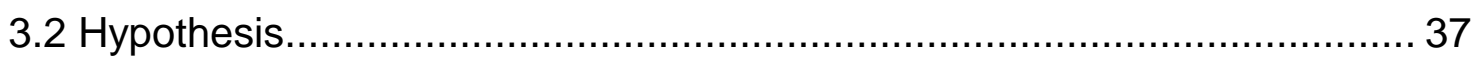

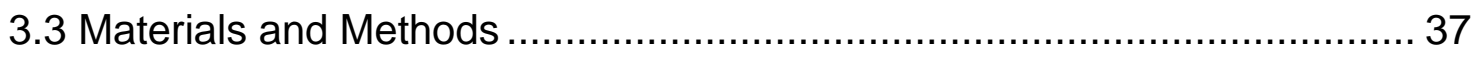

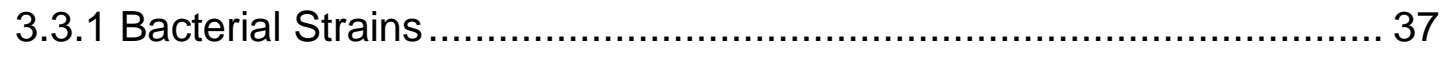

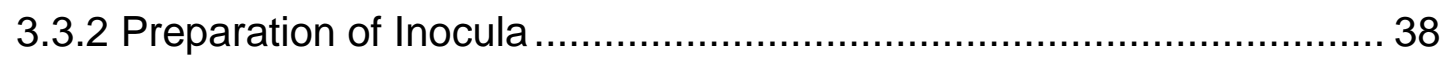

3.3.3 Antimicrobials and Sodium Replacement Agents .............................. 39

3.3.4 Antimicrobial Efficacy Determination................................................. 39

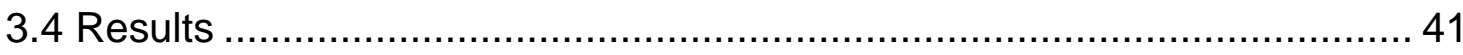


3.4.1 Efficacy of Antimicrobials against Salmonella, E. coli O157:H7,

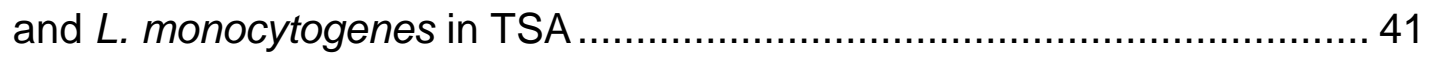

3.4.2 Antimicrobial Activity of Sodium Replacement Agents in TSA ........... 46

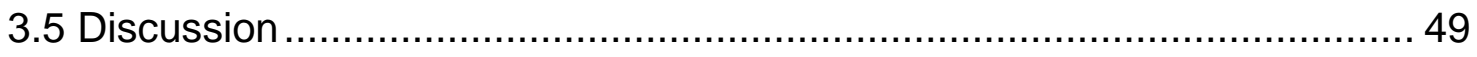

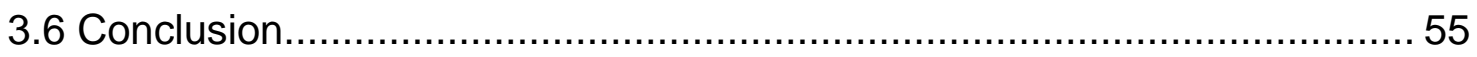

4.0 Antimicrobial Efficacy Screening in Milk Agar......................................... 56

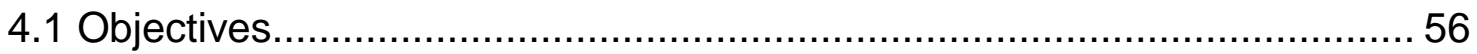

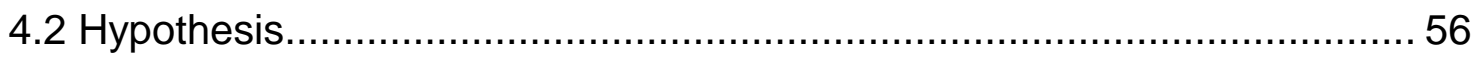

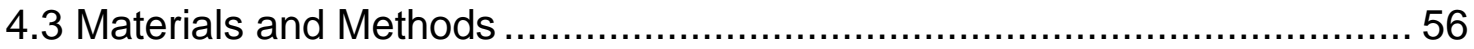

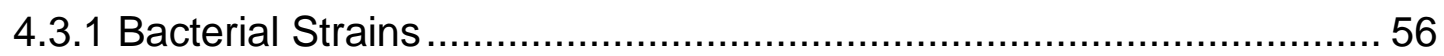

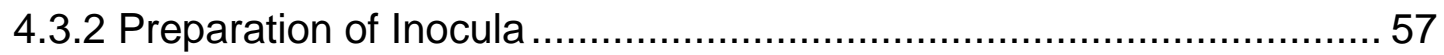

4.3.3 Antimicrobials and Sodium Replacement Agents ............................ 58

4.3.4 Antimicrobial Efficacy Determination............................................. 58

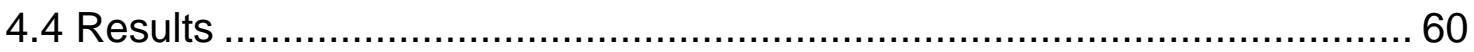

4.4.1 Efficacy of Antimicrobials against Salmonella, E. coli O157:H7,

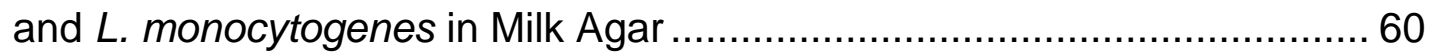

4.4.2 Antimicrobial Activity of Sodium Replacement Agents in Milk Agar .... 64

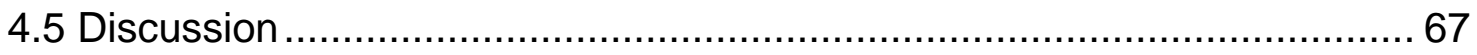

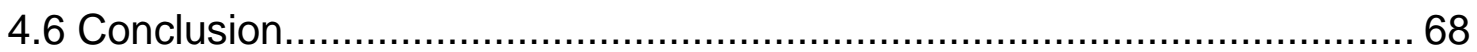

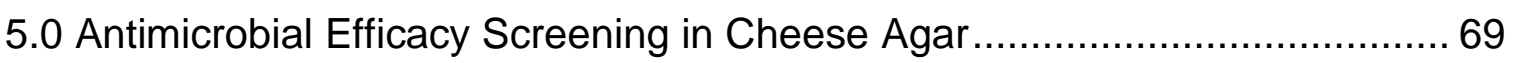

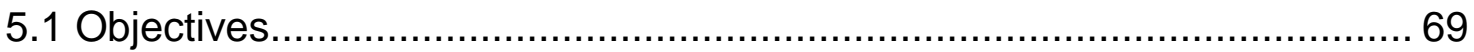

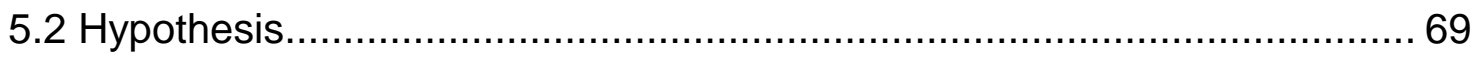

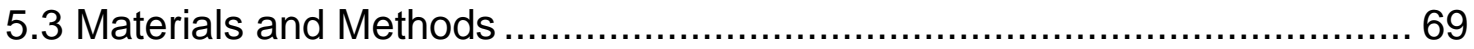




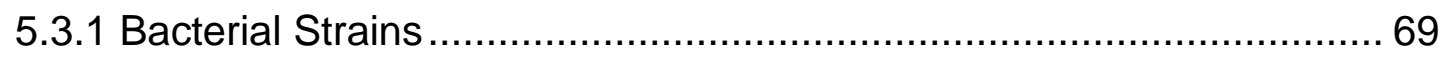

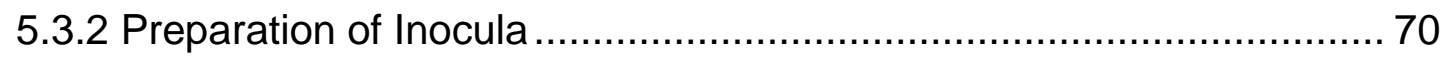

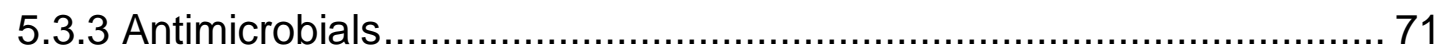

5.3.4 Antimicrobial Efficacy Determination............................................... 71

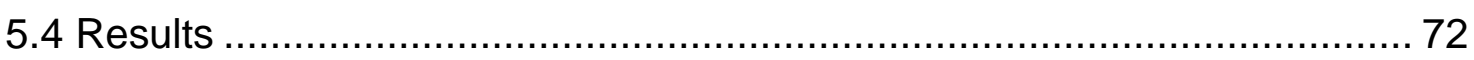

5.4.1 Efficacy of Antimicrobials against Salmonella, E. coli O157:H7, and L. monocytogenes in Regular Sodium Cheese Agar .................. 72

5.4.2 Efficacy of Antimicrobials against Salmonella, E. coli O157:H7, and L. monocytogenes in Low Sodium Cheese Agar ....................... 73

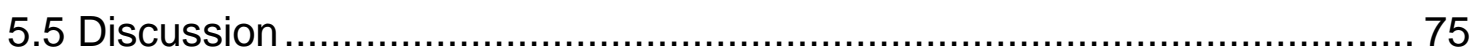

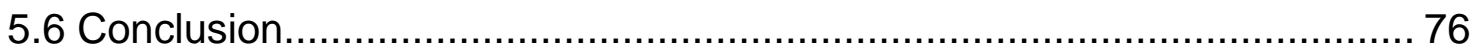

6.0 Antimicrobial and Sodium Replacement Agent Interaction Testing ............. 77

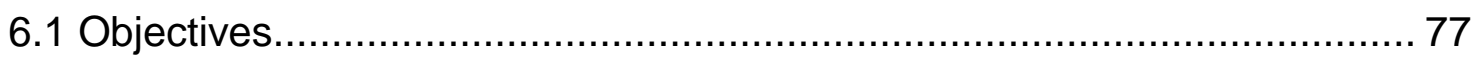

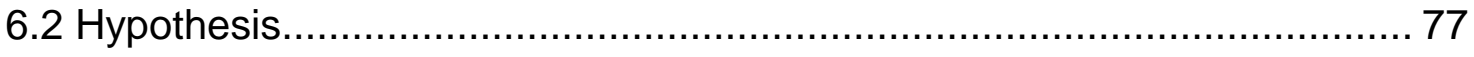

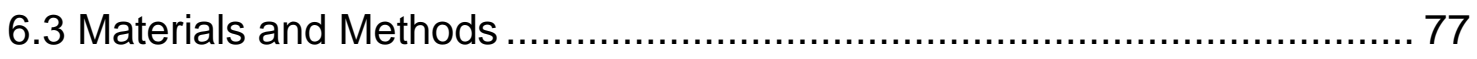

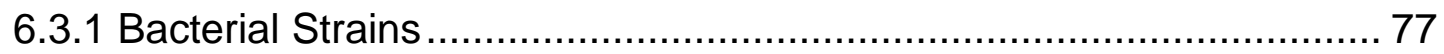

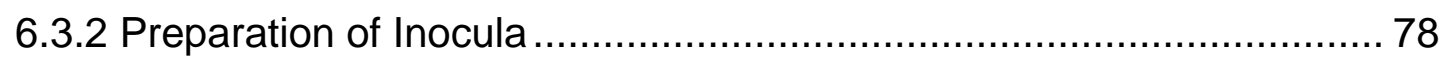

6.3.3 Antimicrobials and Sodium Replacement Agents ............................ 79

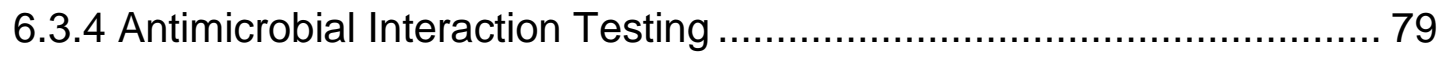

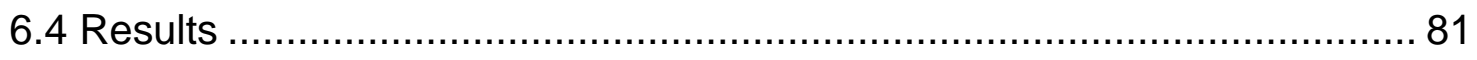

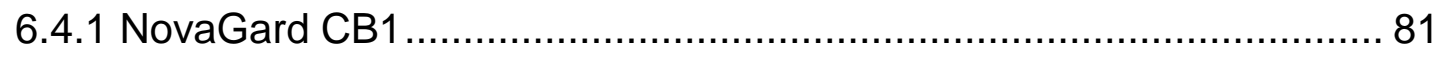

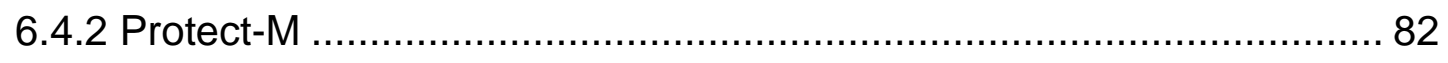

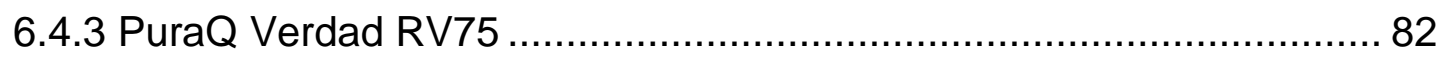




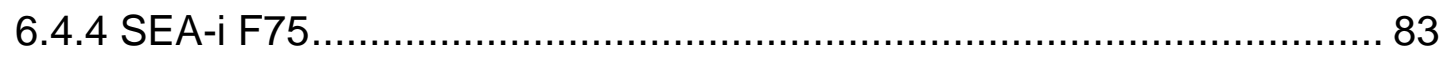

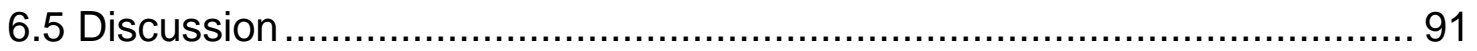

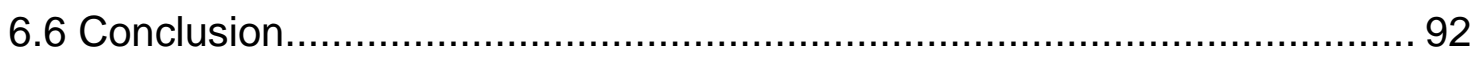

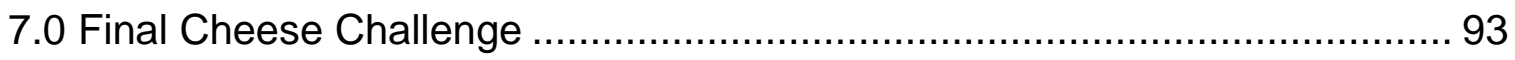

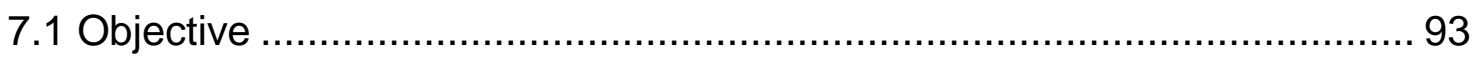

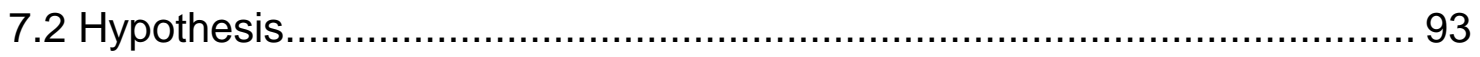

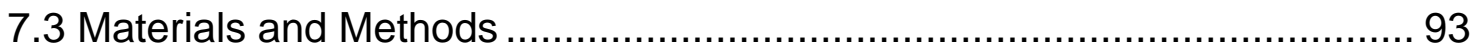

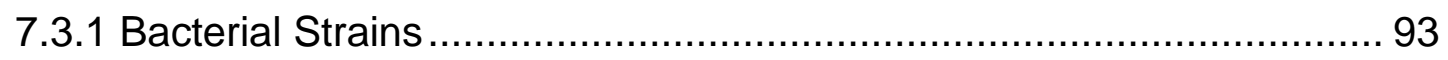

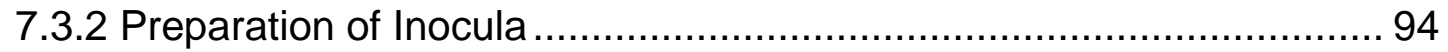

7.3.3 Antimicrobials and Sodium Replacement Agents .............................. 95

7.3.4 Product Formulations and Preparation............................................ 95

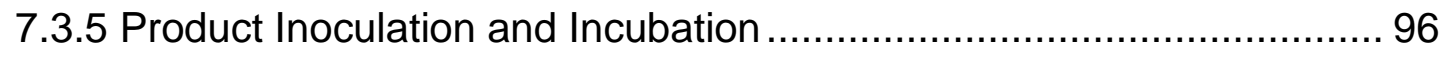

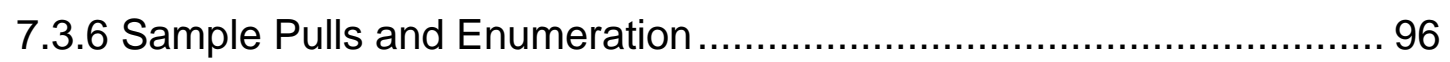

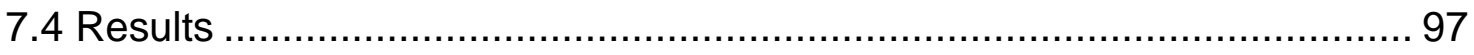

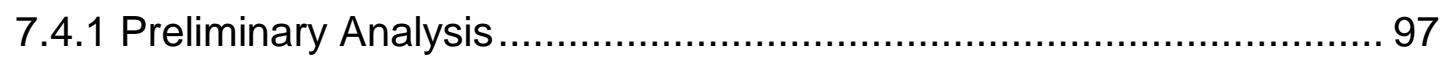

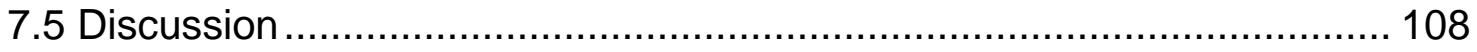

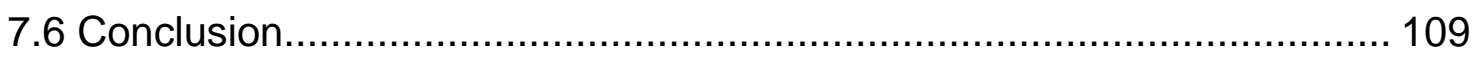

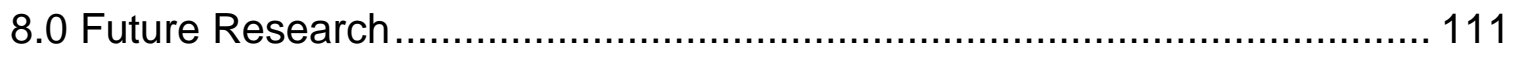

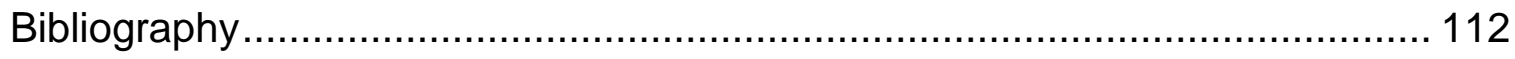

Appendix: Final Cheese Challenge Tables.................................................... 126 


\section{LIST OF TABLES}

2.1 Typical Composition of Mozzarella cheese in the United States ................. 7

2.2 Growth characteristics of pathogenic microorganisms ............................ 14

3.1 Description and concentrations of antimicrobials used to determine antimicrobial efficacy in tryptic soy agar (TSA) screening ......................... 40

3.2 Description and concentrations of sodium replacement agents used to determine antimicrobial efficacy in tryptic soy agar (TSA) screening........ 41

3.3 Growth of Salmonella and E. coli O157:H7 on TSA (pH 5.8) supplemented with MicroGard 100 and incubated at $35^{\circ} \mathrm{C}$

3.4 Growth of Salmonella, E. coli O157:H7 and L. monocytogenes on TSA (pH 5.8) supplemented with MicroGard 430 and incubated at $35^{\circ} \mathrm{C}$.

3.5 Growth of Listeria monocytogenes on TSA ( $\mathrm{pH} 5.8$ ) supplemented with Nisaplin and incubated at $35^{\circ} \mathrm{C}$

3.6 Growth of Salmonella, E. coli O157:H7 and L. monocytogenes on TSA (pH 5.8) supplemented with NovaGard CB1 and incubated at $35^{\circ} \mathrm{C}$

3.7 Growth of Salmonella, E. coli O157:H7 and L. monocytogenes on TSA (pH 5.8) supplemented with Protect-M and incubated at $35^{\circ} \mathrm{C}$

3.8 Growth of Salmonella, E. coli O157:H7 and L. monocytogenes on TSA (pH 5.8) supplemented with PuraQ Verdad RV75 and incubated at $35^{\circ} \mathrm{C}$

3.9 Growth of Salmonella, E. coli $\mathrm{O} 157: \mathrm{H} 7$ and L. monocytogenes on 
TSA (pH 5.8) supplemented with SEA-i F75 and incubated at $35^{\circ} \mathrm{C}$. 45

3.10 Growth of Salmonella, E. coli O157:H7 and L. monocytogenes on TSA (pH 5.8) supplemented with VMY1P and incubated at $35^{\circ} \mathrm{C}$ 46

3.11 Growth of Salmonella, E. coli O157:H7 and L. monocytogenes on TSA (pH 5.8) supplemented with $\mathrm{KCl}$ and incubated at $35^{\circ} \mathrm{C}$. 46

3.12 Growth of Salmonella, E. coli O157:H7 and L. monocytogenes on TSA ( $\mathrm{pH}$ 5.8) supplemented with Puracal PP/USP and incubated at $35^{\circ} \mathrm{C}$

3.13 Growth of Salmonella, E. coli O157:H7 and L. monocytogenes on TSA ( $\mathrm{pH}$ 5.8) supplemented with Purasal Hi Pure P Plus and incubated at $35^{\circ} \mathrm{C}$.

3.14 Growth of Salmonella, E. coli O157:H7 and L. monocytogenes on TSA (pH 5.8) supplemented with PuraQ Verdad NV10 and incubated at $35^{\circ} \mathrm{C}$.

3.15 Growth of Salmonella, E. coli O157:H7 and L. monocytogenes on TSA (pH 5.8) supplemented with SaltWise 0029 and incubated at $35^{\circ} \mathrm{C}$

3.16 Growth of Salmonella, E. coli O157:H7 and L. monocytogenes on TSA supplemented with SaltWise 1029 and incubated at $35^{\circ}$ 48

4.1 Description and concentrations of antimicrobials used to determine antimicrobial efficacy in milk agar screening. 59

4.2 Description and concentrations of sodium replacement agents used to determine antimicrobial efficacy in milk agar. 60 
4.3 Growth of Salmonella and E. coli O157:H7 on milk agar supplemented with MicroGard 100 and incubated at $35^{\circ} \mathrm{C}$.

4.4 Growth of Salmonella, E. coli O157:H7 and L. monocytogenes on milk agar supplemented with MicroGard 430 and incubated at $35^{\circ} \mathrm{C}$.

4.5 Growth of Listeria monocytogenes on milk agar supplemented with

Nisaplin and incubated at $35^{\circ} \mathrm{C}$. 62

4.6 Growth of Salmonella, E. coli O157:H7 and L. monocytogenes on milk agar supplemented with NovaGard CB1 and incubated at $35^{\circ} \mathrm{C}$ 63

4.7 Growth of Salmonella, E. coli O157:H7 and L. monocytogenes on milk agar supplemented with Protect-M and incubated at $35^{\circ} \mathrm{C}$

4.8 Growth of Salmonella, E. coli O157:H7 and L. monocytogenes on milk agar supplemented with PuraQ Verdad RV75 and incubated at $35^{\circ} \mathrm{C}$

4.9 Growth of Salmonella, E. coli O157:H7 and L. monocytogenes on milk agar supplemented with SEA-i $\mathrm{F} 75$ and incubated at $35^{\circ} \mathrm{C}$ 64

4.10 Growth of Salmonella, E. coli O157:H7 and L. monocytogenes on milk agar supplemented with VMY1P and incubated at $35^{\circ} \mathrm{C}$ 64

4.11 Growth of Salmonella, E. coli O157:H7 and L. monocytogenes on milk agar supplemented with $\mathrm{KCl}$ and incubated at $35^{\circ} \mathrm{C}$ 65

4.12 Growth of Salmonella, E. coli O157:H7 and L. monocytogenes on milk agar supplemented with Puracal PP/USP and incubated at $35^{\circ} \mathrm{C}$ 65

4.13 Growth of Salmonella, E. coli O157:H7 and L. monocytogenes on 
milk agar supplemented with Purasal Hi Pure P Plus and incubated at $35^{\circ} \mathrm{C}$. 65

4.14 Growth of Salmonella, E. coli O157:H7 and L. monocytogenes on milk agar supplemented with PuraQ Verdad NV10 and incubated at $35^{\circ} \mathrm{C}$

4.15 Growth of Salmonella, E. coli O157:H7 and L. monocytogenes on milk agar supplemented with SaltWise 0029 and incubated at $35^{\circ} \mathrm{C}$ 66

4.16 Growth of Salmonella, E. coli O157:H7 and L. monocytogenes on mlik agar supplemented with SaltWise 1029 and incubated at $35^{\circ} \mathrm{C}$ 66

5.1 Description and concentrations of antimicrobials used in antimicrobial efficacy screening in regular sodium and low sodium cheese agars. 72

5.2 Growth of Salmonella, E. coli $\mathrm{O} 157: \mathrm{H} 7$ and L. monocytogenes at concentrations of $10^{1}, 10^{2}$ and $10^{4} \mathrm{CFU} / \mathrm{ml}$ on regular sodium cheese agar supplemented with various antimicrobials after incubation at $35^{\circ} \mathrm{C}$

5.3 Growth of Salmonella, E. coli O157:H7 and L. monocytogenes at concentrations of $10^{1}, 10^{2}$ and $10^{4} \mathrm{CFU} / \mathrm{ml}$ on low sodium cheese agar supplemented with various antimicrobials after incubation at $35^{\circ} \mathrm{C}$

6.1 Description and concentrations of antimicrobials used in interaction testing in TSA and milk agar. 80

6.2 Description and concentrations of sodium replacement agents used in interaction testing in TSA and milk agar 
6.3 Growth of Salmonella, E. coli O157:H7 and L. monocytogenes at concentrations of $10^{4} \mathrm{CFU} / \mathrm{ml}$ on TSA (pH 5.8) supplemented with NovaGard CB1 at a concentration of $1.0 \%$ and various sodium replacement agents after incubation at $35^{\circ} \mathrm{C}$. 83

6.4 Growth of Salmonella, E. coli O157:H7 and L. monocytogenes at concentrations of $10^{4} \mathrm{CFU} / \mathrm{ml}$ milk agar supplemented with NovaGard CB1 at a concentration of $1.0 \%$ and various sodium replacement agents after incubation at $35^{\circ} \mathrm{C}$ 84

6.5 Growth of Salmonella, E. coli O157:H7 and L. monocytogenes at concentrations of $10^{4} \mathrm{CFU} / \mathrm{ml}$ on TSA ( $\mathrm{pH}$ 5.8) supplemented with Protect-M at a concentration of $0.2 \%$ and various sodium replacement agents after incubation at $35^{\circ} \mathrm{C}$

6.6 Growth of Salmonella, E. coli $\mathrm{O} 157: \mathrm{H} 7$ and L. monocytogenes at concentrations of $10^{4} \mathrm{CFU} / \mathrm{ml}$ on milk agar supplemented with Protect-M at a concentration of $0.2 \%$ and various sodium replacement agents after incubation at $35^{\circ} \mathrm{C}$. 86

6.7 Growth of Salmonella, E. coli O157:H7 and L. monocytogenes at concentrations of $10^{4} \mathrm{CFU} / \mathrm{ml}$ on TSA ( $\mathrm{pH}$ 5.8) supplemented with PuraQ Verdad RV75 at a concentration of $0.2 \%$ and various sodium replacement agents after incubation at $35^{\circ} \mathrm{C}$.

6.8 Growth of Salmonella, E. coli O157:H7 and L. monocytogenes at concentrations of $10^{4} \mathrm{CFU} / \mathrm{ml}$ on milk agar supplemented with PuraQ Verdad RV75 at a concentration of $0.2 \%$ and various sodium 
replacement agents after incubation at $35^{\circ} \mathrm{C}$.

6.9 Growth of Salmonella, E. coli O157:H7 and L. monocytogenes at concentrations of $10^{4} \mathrm{CFU} / \mathrm{ml}$ on TSA ( $\mathrm{pH}$ 5.8) supplemented with SEA-i F75 at a concentration of $0.25 \%$ and various sodium replacement agents after incubation at $35^{\circ} \mathrm{C}$

6.10 Growth of Salmonella, E. coli O157:H7 and L. monocytogenes at concentrations of $10^{4} \mathrm{CFU} / \mathrm{ml}$ on milk agar supplemented with SEA-i F75 at a concentration of $0.25 \%$ and various sodium replacement agents after incubation at $35^{\circ} \mathrm{C}$. 90

7.1 Formulations of low-moisture part-skim mozzarella cheese used in the final cheese challenge study. 96

7.2 Average $\mathrm{pH}$ and water activity values for uninoculated samples of six formulations of low-moisture part-skim (LMPS) mozzarella cheese after incubation at $4^{\circ}$ and $12^{\circ} \mathrm{C}$.

7.3 Average coliform, yeast, mold and psychrotroph counts (log CFU/g) for uninoculated samples of six formulations of low-moisture part-skim (LMPS) mozzarella cheese after incubation at $4^{\circ}$ and $12^{\circ} \mathrm{C}$ (Trial 1$)$. 100

7.4 Average coliform, yeast, mold and psychrotroph counts (log CFU/g) for uninoculated samples of six formulations of low-moisture part-skim (LMPS) mozzarella cheese after incubation at $4^{\circ}$ and $12^{\circ} \mathrm{C}$ (Trials 2 and 3 ) 101

A.1 Behavior of Listeria monocytogenes in artificially inoculated

xviii 
formulations of low-moisture part-skim (LMPS) mozzarella cheese made with and without sodium replacement agents and SEA-i F75 after incubation at $4^{\circ}$ and $12^{\circ} \mathrm{C}($ Trial 1$)$.

A.2 Behavior of Listeria monocytogenes in artificially inoculated formulations of low-moisture part-skim (LMPS) mozzarella cheese made with and without sodium replacement agents and SEA-i F75 after incubation at $4^{\circ} \mathrm{C}$ (Trials 2 and 3 ).

A.3 Behavior of Listeria monocytogenes in artificially inoculated formulations of low-moisture part-skim (LMPS) mozzarella cheese made with and without sodium replacement agents and SEA-i F75 after incubation at $12^{\circ} \mathrm{C}$ (Trials 2 and 3 ). 128

A.4 Behavior of Salmonella in artificially inoculated formulations of low-moisture part-skim (LMPS) mozzarella cheese made with and without sodium replacement agents and SEA-i F75 after incubation at $4^{\circ}$ and $12^{\circ} \mathrm{C}$ (Trial 1$)$.

A.5 Behavior of Salmonella in artificially inoculated formulations of low-moisture part-skim (LMPS) mozzarella cheese made with and without sodium replacement agents and SEA-i F75 after incubation at $4^{\circ} \mathrm{C}$ (Trials 2 and 3 ). 130

A.6 Behavior of Salmonella in artificially inoculated formulations of low-moisture part-skim (LMPS) mozzarella cheese made with and without sodium replacement agents and SEA-i F75 after incubation at $12^{\circ} \mathrm{C}$ (Trials 2 and 3 ). 131

xix 
A.7 Behavior of E. coli $\mathrm{O} 157: \mathrm{H} 7$ in artificially inoculated formulations of low-moisture part-skim (LMPS) mozzarella cheese made with and without sodium replacement agents and SEA-i F75 after incubation at $4^{\circ}$ and $12^{\circ} \mathrm{C}$ (Trial 1$)$. 132

A.8 Behavior of E. coli $\mathrm{O} 157: \mathrm{H} 7$ in artificially inoculated formulations of low-moisture part-skim (LMPS) mozzarella cheese made with and without sodium replacement agents and SEA-i F75 after incubation at $4^{\circ} \mathrm{C}$ (Trials 2 and 3 ).

A.9 Behavior of E. coli $\mathrm{O} 157: \mathrm{H} 7$ in artificially inoculated formulations of low-moisture part-skim (LMPS) mozzarella cheese made with and without sodium replacement agents and SEA-i F75 after incubation at $12^{\circ} \mathrm{C}$ (Trials 2 and 3 ). 


\section{LIST OF FIGURES}

2.1 Flow chart of the manufacture of mozzarella cheese …............................ 6

2.2 Representation of the glucose oxidase reaction ...................................... 31

7.1 Behavior of $L$. monocytogenes in six formulations of low-moisture part-skim (LMPS) mozzarella cheese during incubation at $4^{\circ} \mathrm{C}$

(Trial 1). 102

7.2 Behavior of L. monocytogenes in six formulations of low-moisture part-skim (LMPS) mozzarella cheese during incubation at $4^{\circ} \mathrm{C}$ (Trial 2) 102

7.3 Behavior of L. monocytogenes in six formulations of low-moisture part-skim (LMPS) mozzarella cheese during incubation at $12^{\circ} \mathrm{C}$

(Trial 1) 103

7.4 Behavior of L. monocytogenes in six formulations of low-moisture part-skim (LMPS) mozzarella cheese during incubation at $12^{\circ} \mathrm{C}$

(Trial 2). 103

7.5 Behavior of Salmonella in six formulations of low-moisture part-skim

(LMPS) mozzarella cheese during incubation at $4^{\circ} \mathrm{C}$ (Trial 1$)$. 104

7.6 Behavior of Salmonella in six formulations of low-moisture part-skim (LMPS) mozzarella cheese during incubation at $4^{\circ} \mathrm{C}$ (Trial 2). 104

7.7 Behavior of Salmonella in six formulations of low-moisture part-skim (LMPS) mozzarella cheese during incubation at $12^{\circ} \mathrm{C}$ (Trial 1). 105

7.8 Behavior of Salmonella in six formulations of low-moisture part-skim (LMPS) mozzarella cheese during incubation at $12^{\circ} \mathrm{C}$ (Trial 2). 105 
7.9 Behavior of E. coli $\mathrm{O} 157: \mathrm{H} 7$ in six formulations of low-moisture part-skim (LMPS) mozzarella cheese during incubation at $4^{\circ} \mathrm{C}$

(Trial 1) 106

7.10 Behavior of E. coli $\mathrm{O} 157: \mathrm{H} 7$ in six formulations of low-moisture part-skim (LMPS) mozzarella cheese during incubation at $4^{\circ} \mathrm{C}$ (Trial 2). 106

7.11 Behavior of $E$. coli $\mathrm{O} 157: \mathrm{H} 7$ in six formulations of low-moisture part-skim (LMPS) mozzarella cheese during incubation at $12^{\circ} \mathrm{C}$ (Trial 1) 107

7.12 Behavior of $E$. coli $\mathrm{O} 157: \mathrm{H} 7$ in six formulations of low-moisture part-skim (LMPS) mozzarella cheese during incubation at $12^{\circ} \mathrm{C}$ (Trial 2). 107 


\subsection{Introduction:}

Dairy products have been implicated in foodborne outbreaks. Of the 4,438 foodborne outbreaks recorded form 1999 to $2008,4.7$ percent were linked to dairy products (DeWaal et al., 2012). Outbreaks have been associated with several pathogenic organisms including E. coli O157:H7, Listeria monocytogenes and Salmonella. Since pasteurization of milk eliminates vegetative pathogens, dairy-related outbreaks are typically linked to unpasteurized milk, improper pasteurization or post-pasteurization contamination (Reij and Aantrekker, 2004). Routes of post-pasteurization contamination include poor hygiene of food handlers, improper sanitation of processing equipment and insufficient air filtration in processing environments. Enhancing sanitary practices in food processing facilities will decrease the likelihood of post-pasteurization contamination, but will not completely eliminate the risk.

To prevent the growth or survival of pathogens, in case of contamination, many dairy products are formulated with ingredients that provide mild preservation, or microbial hurdles, which work in combination to control microbial spoilage (Leistner and Gorris, 1995). These microbial hurdles may include low $\mathrm{pH}$, high salt content, low water activity or the addition of sugar, nitrites or other preservatives. In cheese, the common hurdles include the reduction in $\mathrm{pH}$ due to the addition of lactic acid bacteria and the addition of salt in the production of cheese. Salt is added to food for its flavor as well as its antimicrobial properties (Guinee, 2004). Adding salt to food lowers the water activity, reducing the water available for microorganisms and preventing their growth (Guraya et al., 1998; 
Larson et al., 1993). While these factors can prevent the growth of pathogens and help to ensure microbial safety, high consumption of the key hurdle, salt, can have a negative effect on human health (Appel and Anderson, 2010).

High salt intake has been linked with chronic heart disease and has been identified as one of the primary preventable factors in both obesity and hypertension (Sacks et al., 2001). Cheese, though dense in nutrients such as protein, phosphorus and calcium, is also perceived as being high in sodium (Johnson et al., 2009). Reducing the sodium in cheese, while conferring a benefit to the consumer, would also remove an important food safety hurdle and potentially alter the microbial stability of the product. To address the potential of reduced microbial safety another hurdle, such as an antimicrobial, would need to be introduced into the food matrix.

Limited research has been done to evaluate other commercially available antimicrobials that could potentially provide effective inhibition of pathogens in dairy products. Previous research has primarily focused on the efficacy of bacteriocins, such as nisin, at inhibiting the growth of pathogens in agar and dairy products (Arques et al., 2008a; Arques et al., 2008b; Arques et al., 2011; Cleveland et al., 2001; Hammer et al., 1999; Oussalah et al., 2007a; Samelis et al., 2003; Stevens et al., 1991). Additionally, studies about potential salt replacers have predominantly focused on the partial replacement of sodium chloride with potassium chloride (Bidlas and Lambert, 2008; Katsiari et al., 1997). Partial replacement with $\mathrm{KCl}$ can be effective at inhibiting pathogenic growth, but $\mathrm{KCl}$ may impart an unwanted bitter taste in dairy products. Additional options for 
preventing the growth of pathogens in the event of contamination need to be fully explored.

This study aims to identify antimicrobials and compatible salt substitutes for use in the low sodium low-moisture part-skim (LMPS) mozzarella cheese. The objectives were to screen several commercially available antimicrobials to determine their potential for inhibiting the growth of Salmonella, $L$. monocytogenes, and E. coli $\mathrm{O} 157: \mathrm{H} 7$ in different agar systems, screen salt substitutes for potential antimicrobial activity, to look for interactions between antimicrobials and salt replacers and to perform a final challenge study with a suitable antimicrobial in low sodium LMPS mozzarella cheese. 


\subsection{Literature Review}

\subsection{Low-Moisture Part-Skim Mozzarella Cheese}

\subsubsection{Cheese Consumption in the US}

Cheese consumption is currently on the rise in the United States. Over the last twenty years, average cheese consumption has nearly tripled (Buzby, 2005). Mozzarella cheese, mostly low-moisture part-skim (LMPS) mozzarella, has recently overtaken cheddar as the most popular cheese in the US. In 2003, consumption of mozzarella averaged 9.6 pounds per person (Buzby, 2005). The popularity of LMPS mozzarella cheese is largely attributed to its wide use in American-style pizza and the manufacture of string cheese (Fuquay et al., 2011). The increase in cheese consumption increases the need for dairy manufacturers to produce a safe product. Since a large portion of mozzarella consumers are from a susceptible population, children and the elderly, the risk of developing food borne illness in the case of pathogenic contamination is high.

\subsubsection{Cheese Manufacture and Composition}

Cheese is defined as a curd of milk solids produced by the coagulation of casein and the trapping of milk fat in the coagulum (Fernandes, 2009). LMPS mozzarella is made on a large scale and initially manufactured similarly to other semihard cheeses (Figure 2.1). First, pasteurized milk is added to a cheese vat. 
Milk is then standardized to a casein-to-fat ratio of 1.2 through either the removal of cream or by adding extra solids through the addition of liquid skim milk concentrate or nonfat dry milk (NFDM) powder. Milk is then acidified to a pH of $5.0-5.3$ through either chemical (direct) acidification or biological (culture) acidification methods. In direct acidification, organic acids, such as citric acid or acetic acid, are used to decrease the $\mathrm{pH}$ of the milk. Culture acidification utilizes lactic acid bacteria to produce lactic acid from the milk lactose, eventually decreasing the milk $\mathrm{pH}$. Direct acidification, though more easily controllable, does not contribute to ripening or flavor development, thus culture acidification, using thermophilic cultures, is typically utilized in LMPS mozzarella (Jana and Mandal, 2011).

Once the milk has reached the target $\mathrm{pH}$, rennet, a milk-clotting enzyme, is added to coagulate the milk. After the coagulum forms, it is cut, and the curd and whey are stirred and heated from $35^{\circ} \mathrm{C}$ to $40^{\circ} \mathrm{C}$. When the $\mathrm{pH}$ of the curd reaches 6.2-6.3, the whey is drained and the curd is dry stirred to allow for more complete acidification and syneresis of the whey. At a pH of 5.3, the curd is removed from the vat, put into the cooker/stretcher then extruded, which aligns the cheese fibers into parallel strands, giving the cheese its characteristic elastic, stringy texture. After extrusion, the cheese is brine-salted, molded into the desired form, then individually vacuum packaged.

LMPS mozzarella cheese standards of identity include having a minimum milkfat content of greater than 30 percent, but no more than 45 percent, and a moisture content of more than 45 percent but less than 52 percent 
(21CFR133.156; 21CFR133.157). Final Mozzarella cheese is primarily composed of water, protein and fat (Table 2.1).

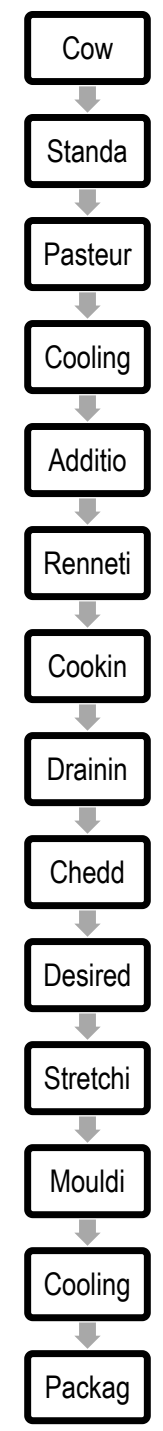

Figure 2.1 Flow chart of the manufacture of mozzarella cheese.

Source: Jana, A. H., \& Mandal, P. K. (2011). Manufacturing and Quality of Mozzarella Cheese: A Review. International Journal of Dairy Science, 6(4), 199-226. 
Table 2.1 Typical composition of Mozzarella cheese in the United States.

\begin{tabular}{ll} 
Component & \\
\hline Moisture (\%) & $45-52$ \\
Protein (\%) & 20 \\
Fat (\%) & $30-45$ \\
Lactose (\%) & 1.5 \\
Ash (\%) & $2-4$ \\
Salt (NaCl) & $546-814 \mathrm{mg} /$ serving \\
\hline
\end{tabular}

Source: Agarwal, S., McCoy, D., Graves, W., Gerard, P. D., \& Clark, S. (2011). Sodium content in retail Cheddar, Mozzarella, and process cheeses varies considerably in the United States. [Article]. Journal of Dairy Science, 94(3), 1605-1615; Jana, A. H., \& Mandal, P. K. (2011). Manufacturing and Quality of Mozzarella Cheese: A Review. International Journal of Dairy Science, 6(4), 199-226.

\subsubsection{Consumer Health Concerns with Cheese Products}

Consumers have recently become concerned with levels of salt intake. this increased concern has encouraged some consumers to decrease their intake of processed foods. Processed foods typically contain high levels of salt and, since cheese is considered a processed food, it is perceived as being high in sodium. Average salt content of cheese ranges from $0.5-0.7 \%$ in acid curd cheeses to $4-6 \%$ in pickled cheeses (Guinee, 2004). Though the recommended daily intake of sodium is less than $5.8 \mathrm{~g}$ of salt, in the US daily salt intake averages $10.4 \mathrm{~g}$ for men and $7.3 \mathrm{~g}$ for women (Bibbins-Domingo et al., 2010). Excessive dietary sodium has been shown to have detrimental effects on cardiovascular health; there is a strong causal relationship between high dietary salt intake and hypertension (Kornitzer et al., 1999; Mohan and Campbell, 2009). Hypertension is the major cause of cardiovascular disease, ahead of smoking and raised cholesterol (He et al., 2009; Kung et al., 2008). Increased 
hypertension prevalence reflects a continuing need for reducing sodium intake through health policy and individual practice (Fields et al., 2004).

It has been estimated that a national effort to reduce salt by $3 \mathrm{~g}$ a day could reduce the annual number of new cases of coronary heart disease by 60,000 to 120,000 , stroke by 32,000 to 66,000 , myocardial infraction by 54,000 to 90,000 and annual deaths by 44,000 to 92,000 ; reduction of dietary sodium could also potentially save $\$ 10$ billion to $\$ 24$ billion in health care costs annually (Appel and Anderson, 2010). Population intervention studies that successfully reduced salt intake observed a decrease in blood pressure (He and MacGregor, 2009). Reducing consumer salt intake in Japan from an average of 13.5 to $12.1 \mathrm{~g} /$ day was associated with an $80 \%$ reduction in stroke mortality, as well as a decrease in blood pressure in both adults and children. Earlier research done by Sacks, et al. (2001), showed that reducing the sodium chloride content of typical diets in the US by $140 \mathrm{mmol}$ per day led to decreases in blood pressure. Decreasing the incidence of hypertension through salt reduction would be highly effective and inexpensive and could be as beneficial as interventions aimed at smoking cessation and weight reduction (Ferrante et al., 2011).

The two main ways to decrease dietary salt intake are by processors reducing levels of salt in processed and prepared foods or consumers selecting and preparing food with little or no salt. Since roughly $75 \%$ of dietary salt comes from processed foods, the most effective way to decrease salt intake would be through the reduction of added sodium during processing (Appel and Anderson, 2010; Bibbins-Domingo et al., 2010). However, since salt plays many functional 
roles in processed foods, several issues arise when reducing sodium in processed foods, including unfavorable changes to product flavor and decreased shelf life stability.

\subsection{Salt Reduction Challenges}

\subsubsection{Importance of Salt in Cheese}

Salt, in the form of $\mathrm{NaCl}$, plays several direct and indirect roles in cheese. Salt helps to enhance flavor by controlling the metabolism of the starter bacteria and the activity of enzymes, as well as providing consumers with the characteristic salty taste in cheese (Johnson et al., 2009). Fermentation processes rely on salt to inhibit the proliferation of undesirable microorganisms while permitting the growth of starter bacteria and native microflora (Taormina, 2010). Salt also affects the level of proteolysis by controlling the rate and extent of fermentation. Reducing the concentration of salt in cheese can cause abnormal fermentations, resulting in increases in proteolysis, acidity and bitterness, as well as decreases in firmness and saltiness (Agarwal et al., 2011; Katsiari et al., 1997).

Salt also acts as a preservative in cheese; it has some of the most effective antimicrobial properties against foodborne pathogens and spoilage organisms (Taormina, 2010). Salt is able to stop or slow the growth of microorganisms through the reduction in water activity, as well as disrupting transfer through cellular membranes (McMahon, 2010). Removing salt from 
cheese, thereby raising the water activity, could diminish food safety and allow pathogens to grow or persist during processing (Taormina, 2010).

\subsubsection{Microbial Safety}

\subsubsection{Sources of Contamination}

Dairy product stability is a result of intrinsic properties, such as $\mathrm{pH}, \mathrm{a}_{\mathrm{w}}$ and salt, combined with pasteurization for microbial preservation and safety. In the absence of refrigeration or a key microbial hurdle, such as salt, the composition of dairy products can provide a favorable environment for growth. The majority of dairy products are ready-to-eat (RTE) and their composition provides a favorable physical and chemical environment for the growth and propagation of a broad spectrum of microorganisms (Hotchkiss et al., 2006).

There are several routes through which microorganisms can contaminate dairy foods: a lack of pasteurization, inadequate pasteurization or postpasteurization microbial recontamination (Hotchkiss et al., 2006).

\subsection{Unpasteurized Cheese Products. Recently, consumer}

interests have shifted towards minimally processed foods, including unpasteurized cheese products. The consumption of unpasteurized milk carries with it some health concerns, as it can easily be contaminated with pathogens at the farm and processing levels. Mastitis, an infection of the udder of the cow, is one of the pathways by which pathogens are shed into milk. Staphylococcus 
aureus is one of the major causes of mastitis in dairy cows (Fuquay et al., 2011). Infections can cause up to $10^{8} \mathrm{CFU} / \mathrm{ml}$ of the organism to be shed into milk. Salmonella spp., Listeria monocytogenes and E. coli $\mathrm{O} 157: \mathrm{H} 7$, though uncommon, have also been found to cause mastitis or colonize udders (Kousta et al., 2010). Improper cleaning of udders, or milking machines, can lead to the shedding excretion of pathogens into milk.

Several other factors at dairy farms influence the prevalence of pathogens in raw milk, including the farm size, number of animals on the farm and the season (Kousta et al., 2010). Using raw milk contaminated with high levels of pathogenic bacteria to produce cheese could potentially result in contaminated cheese. Though cheese produced from unpasteurized milk is aged for 60 days prior to consumption, several studies have shown that the aging requirement is not sufficient enough to eliminate the presence of pathogens (D'Amico et al., 2010; Maher et al., 2001; Schlesser et al., 2006).

2.2.1.2 Recontamination of Cheese Products. Microorganisms can also contaminate dairy products through recontamination after processing. WHO (1995), determined that almost 25 percent of foodborne outbreaks could be traced back to recontamination (Reij and Aantrekker, 2004). There are several routes of recontamination, including cross contamination between raw and processed foods, the introduction of pathogens into the processing environment, and the lack of hygienic practices during the processing and production by dairy workers. Additionally, contaminated raw materials or ingredients could 
inadvertently be added to finished products through the contamination of food contact surfaces or processing equipment. Ineffective or inadequate cleaning and disinfection of contaminated food contact surfaces would lead to recontamination.

L. monocytogenes presents the largest challenge to the safety of dairy foods due to its ability to withstand low $\mathrm{pH}$ and refrigeration conditions. Preventing $L$. monocytogenes from establishing a niche and growing in the processing environment is a major focus of dairy facilities (Tompkin et al., 1999). Food processing equipment has several niches, or harborage sites, on food contact and non-food contact surfaces, that are difficult to clean and frequently missed during regular cleanings (Grinstead and Cutter, 2007). Without effective cleaning, L. monocytogenes is able to grow and form biofilms. The formation of biofilms by L. monocytogenes makes it more difficult to kill with sanitizers and disinfectants due to the protective film or slime layer associated with the biofilm (Grinstead and Cutter, 2007); this factor enhances the resistance of $L$. monocytogenes to cleaning and sanitation, thereby promoting its transmission to food (Adetunji and Adegoke, 2008).

In addition to processing equipment, cheese can be contaminated via cheese brines (Kousta et al., 2010). Commercial cheese brines are often used repeatedly and may be pasteurized infrequently or not at all. Brines are contaminated through cheese made from unpasteurized milk or by the unintentional addition of unpasteurized milk to the brine. Once the brine is contaminated, microorganisms can be spread to cheeses in other batches during 
brining. Salmonella, E. coli O157:H7 and L. monocytogenes have been shown to survive for greater than seven days in cheese brines (Ingham et al., 2000; Larson et al., 1999).

The potential risk for the recontamination of dairy products in the processing environment highlights the importance of antimicrobial hurdles in the formulation. Formulating product with intrinsic antimicrobial properties would prevent the growth or survival of the bacteria in the case of pathogenic contamination.

\subsubsection{Pathogen Growth and Survival in Cheese}

Cheeses, as they are naturally formulated, will support the survival and/or growth of pathogens if they are introduced via the raw milk or the processing environment. Pathogens are ubiquitous in nature and several factors, including the ability to withstand lower $\mathrm{pH}$ values and refrigerated temperatures, contribute to their growth and survival in cheese (Table 2.2). L. monocytogenes and some strains of Salmonella spp. have the ability to grow at refrigeration temperatures. E. coli $\mathrm{O} 157: \mathrm{H7}$ and Salmonella have the capability of growing at $\mathrm{pH}$ values as low as 4.5. The growth and survival patterns of E. coli O157:H7, L. monocytogenes, Salmonella spp. and Staph. aureus have been well studied in cheese. 
Table 2.2 Growth characteristics of pathogenic microorganisms ${ }^{1}$.

\begin{tabular}{lccc}
\hline Organism & $\begin{array}{c}\text { Growth } \\
\text { Temperature Range }\end{array}$ & $\begin{array}{c}\text { Optimum Growth } \\
\text { Temperature Range }\end{array}$ & $\begin{array}{c}\text { Lowest } \mathrm{pH} \\
\text { Tolerated for } \\
\text { Growth }\end{array}$ \\
\hline E. coli O157: $\mathrm{H7}$ & $10-45^{\circ} \mathrm{C}$ & $30-42^{\circ} \mathrm{C}$ & 4.5 \\
L. monocytogenes & $1-44^{\circ} \mathrm{C}$ & $30-37^{\circ} \mathrm{C}$ & 5.0 \\
Salmonella spp. & $5-46^{\circ} \mathrm{C}$ & $35-37^{\circ} \mathrm{C}$ & 4.5 \\
Staph. aureus & $7-48^{\circ} \mathrm{C}$ & $20-37^{\circ} \mathrm{C}$ & 4.8 \\
\hline
\end{tabular}

Source: Ray, B., \& Bhunia, A. (2008). Fundamental Food Microbiology (4th ed.). Boca Raton, FL: CRC Press.

2.2.2.2.1 E. coli O157:H7. E. coli O157:H7 cells can persist and proliferate during the manufacture and storage of a variety of cheese products. Reitsma \& Henning (1996) showed that, in cheddar cheese, E. coli O157:H7 could survive the manufacturing process, as well as the minimum 60 day curing period at a temperature greater than or equal to $2^{\circ} \mathrm{C}$. The organism was also able to survive the manufacturing process of mozzarella despite a stretching temperature of $70^{\circ} \mathrm{C}$ (Spano et al., 2003). Cells have survived and grown during the manufacture and storage of paneer, an Indian cheese, at $4^{\circ}, 8^{\circ}$ and $28^{\circ} \mathrm{C}$ (Wahi et al., 2006). By the end of the $48 \mathrm{~h}$ storage, E. coli O157:H7 counts had increased by over 1 log CFU/g over all temperatures tested.

During cold storage, E. coli O157:H7 will not grow. However, the organism can survive and, with its low infective dose, potentially cause illness. Another study showed that $E$. coli $\mathrm{O} 157: \mathrm{H} 7$ persisted in soft cheese samples stored at $8^{\circ} \mathrm{C}$ during a two month incubation and grew when incubated at $10^{\circ}$ and $30^{\circ} \mathrm{C}$ (Kasrazadeh and Genigeorgis, 1995). E. coli O157:H7 has also been shown to survive in an acidified dairy food. The organism was able to grow at 
$12^{\circ} \mathrm{C}$ in dairy products at $\mathrm{pH}$ values of 5 and 5.4 , as well as survive at $\mathrm{pH} 4.7$ with up to $4 \%$ salt concentration (Guraya et al., 1998). Additionally, cells could survive in white cheese $(0.5 \% \mathrm{NaCl})$ at a $\mathrm{pH}$ of 3.9 for over 20 days when stored at $7^{\circ} \mathrm{C}$.

2.2.2.2. Salmonella spp. Several studies have evaluated the behavior of Salmonella in cheese. In brie cheese, Salmonella counts increased during storage at $20^{\circ} \mathrm{C}$ and, though counts declined slowly at $4^{\circ}$ and $8^{\circ} \mathrm{C}$, the organism was present in the cheese for up to 35 days (Little and Knochel, 1994).

Salmonella was introduced into regular and low salt (0.7\%) cheddar cheese as a post-aging contaminant (Shrestha et al., 2011b). In regular cheddar cheese, Salmonella was undetectable by plating after 30,30 and 20 days when incubated at $4^{\circ}, 10^{\circ}$ and $21^{\circ} \mathrm{C}$, respectively. However, when artificially inoculated into low salt cheddar cheese, Salmonella was present throughout incubation at $4^{\circ}, 10^{\circ}$ and $21^{\circ} \mathrm{C}$ for up to 90,90 and 30 days, respectively.

Another study evaluated the behavior of Salmonella during the manufacture of cheddar cheese. Salmonella was introduced at one of several stages of cheddar cheese manufacture: in the raw milk, immediately after pasteurization, mixed with lactic starter before adding or via utensils (White and Custer, 1976). Salmonella survived manufacture and storage of the cheddar cheese at $4.5^{\circ} \mathrm{C}$ for at least 5 months regardless of the pathogen addition stage. Additionally, Salmonella has been shown to survive the manufacture and ripening of raw milk cheeses. In herby and montasio cheeses, traditionally made 
from raw milk, Salmonella survived when ripened for 90 days at $4^{\circ} \mathrm{C}$ (Alemdar and Agaoglu, 2010; Stecchini et al., 1991).

2.2.2.2.3 Staphylococcus aureus. Staph. aureus is a concern in the dairy industry due to the organism's growth characteristics and ecological niche. Staph. aureus can be found in the nostrils, and on the hair and skin of humans, increasing the likelihood of its introduction to foods during processing.

Additionally, the organism has been shown to grow at $\mathrm{pH}$ values as low as 4.2 and $\mathrm{NaCl}$ concentrations up to $15 \%$, allowing it to persist in a variety of fermented foods, such as cheese (Reference).

Previous research of the behavior of Staph. aureus in different cheeses has displayed the organism's survival and growth during manufacture, ripening and storage. A semihard, uncooked, raw milk cheese supported the survival of Staph. aureus during manufacture (Delbes et al., 2006). After manufacture, counts of Staph. aureus ranged from 2.82 to $6.84 \log$ CFU/g. Staph. aureus survived ripening at $12^{\circ} \mathrm{C}$ in a montasio cheese and cheeses manufactured with commercial lactic cultures for 90, 60 and 30 days, respectively (Arques et al., 2005; Rodriguez et al., 2005; Stecchini et al., 1991). During a 12 day storage period at $10^{\circ} \mathrm{C}$ Staph. aureus grew over $4 \log \mathrm{CFU} / \mathrm{g}$ in cuajada, a semisolid dairy product, (Arques et. al, 2008a). Staph. aureus was introduced into Machego cheese, manufactured from raw ewes' milk and ripened for 60 days at 
$10^{\circ} \mathrm{C}$ (Nunez et al., 1988). The organism survived the entire ripening period, but staphylococcal enterotoxins were not detected in any of the samples.

The growth and survival of Staph. aureus has been researched in several fermented products, however, in order to cause illness, the organism must be able to grow and produce toxin in the food matrix. Staph. aureus has been shown to produce toxin in a cheese matrix. The organism was introduced in a Camembert-type cheese, produced from raw goats' milk, at several different inoculum levels (Meyrand et al., 1998). Results showed that Staph. aureus grew by $2-3 \log C F U / g$ and that enterotoxin was detected during the 41 day storage at $4^{\circ} \mathrm{C}$.

2.2.2.2.4 Listeria monocytogenes. L. monocytogenes is arguably the most challenging pathogen in the dairy industry. The organism is able to withstand many of the hurdles intrinsic to dairy products including high salt levels and refrigeration temperatures. If introduced in the processing environment, $L$. monocytogenes can persist through the formation of sanitizer resistant biofilms, which can potentially contaminate final product. Additionally, L. monocytogenes is psychrotrophic, allowing it to grow at refrigeration temperatures.

L. monocytogenes survival and growth in dairy products is well documented. L. monocytogenes was able to survive in Greek-style Galotyri cheese for 28 days at $4^{\circ} \mathrm{C}$ and up to 14 days at $12^{\circ} \mathrm{C}$ (Rogga et al., 2005). $L$. monocytogenes survived for 90,90 and 30 days in cheddar cheese when incubated at $4^{\circ}, 10^{\circ}$ and $21^{\circ} \mathrm{C}$, respectively (Shrestha et al., 2011a). No 
decrease in L. monocytogenes counts was observed over the 12 day incubation at $10^{\circ} \mathrm{C}$ when the organism was artificially inoculated into cuajada, a semisolid dairy product (Arques et al., 2008a).

Studies have shown that $L$. monocytogenes will grow rapidly when cheeses are formulated with reductions in microbial hurdles. Queso fresco cheese is associated with high risk of $L$. monocytogenes contamination due to its low salt content, near neutral $\mathrm{pH}(6.0-6.5)$ and high moisture content. If $L$. monocytogenes were to contaminate queso fresco cheese, the lack of microbial hurdles would permit rapid growth, even at refrigeration temperatures. The concentration of $L$. monocytogenes increased by $4-5 \log$ CFU/g after 28-35 days of incubation at $4^{\circ} \mathrm{C}$ in queso fresco cheese (Leggett et al., 2012; Soni et al., 2012; Soni et al., 2010). When the incubation temperature was increased to $10^{\circ} \mathrm{C}$, the same log increase was observed after only 10 days.

Studies listed above have shown that pathogens can survive the manufacture, ripening and storage of different cheeses. Additionally, inoculated cheeses formulated with reductions in any of the microbial hurdles (i.e. lower salt content, increased $\mathrm{pH}$ ) displayed more rapid growth rates. These results highlight the importance substituting removed or reduces microbial hurdles in order to maintain microbial stability. 


\subsubsection{Cheese-Related Outbreaks}

The consumption of cheeses contaminated with pathogens and their toxins can cause serious foodborne illness problems, threatening human health and causing large economic losses. Of the 209 dairy-related outbreaks reported from 1999 to 2008, almost 30\% involved cheese (DeWaal et al., 2012). Cheese has been the vehicle for several pathogenic outbreaks involving E. coli $\mathrm{O} 157: \mathrm{H} 7$, Salmonella spp., Staphylococcus aureus and Listeria monocytogenes. In the majority of outbreak cases listed below, a microbial hurdle was either reduced or removed, permitting the growth of the pathogen and causing illness.

2.2.2.3.1 E. coli O157:H7. Outbreaks of E. coli O157:H7 in cheese have largely been associated with the consumption of unpasteurized products or final products that have contaminated with unpasteurized milk. Removing the thermal processing hurdle put the final product at greater risk for contamination. Thirtyeight people were affected by an E. coli $\mathrm{O} 157: \mathrm{H} 7$ outbreak linked to unpasteurized Bravo Farms Dutch-style Gouda cheese (CDC, 2010). Fifteen people were hospitalized and one case of HUS was reported, but there were no deaths. The exact cause of this outbreak is unknown. The FDA investigation revealed that there were no other implicated cheese products and it was not clear how long cheese had been aged.

In 1998, pasteurized fresh cheese curds were implicated in an E. coli O157:H7 outbreak (CDC, 1998). Fifty-five laboratory cases were identified and twenty-five people were hospitalized, but there were no reported fatalities. The 
outbreak was traced back to cheese vats that had been used to produce raw milk cheeses prior to the production of pasteurized fresh cheese curds.

In July 2010, Sally Jackson cheeses were implicated in a multistate $E$. coli O157:H7 outbreak (Rothschild, 2010). Eight people were affected and two were hospitalized. The outbreak strain was isolated from the production facility and, while the exact cause of the outbreak is unknown, processing conditions could have led to unpasteurized milk coming into contact with final cheese product. Preventing E. coli O157: $\mathrm{H} 7$ contamination is of great concern in the food industry due to the low infectious dose of the organism; no growth is necessary in order to cause illness.

2.2.2.3.2 Salmonella spp. Salmonella has also been associated with outbreaks related to unpasteurized cheeses. A Salmonella Typhimurium outbreak was linked to raw milk and cheese consumption in Pennsylvania (CDC, 2007). A total of twenty-nine cases were identified; two were hospitalized, but no deaths were reported. Inspections of the implicated dairy revealed improper cleaning of milking equipment and insufficient supervision of workers, along with bird and rodent infestation. In another outbreak, raw milk queso fresco cheese contaminated with Salmonella Typhimurium sickened fifty-four people and caused five hospitalizations (Villar and Macek, 1997). Also, unpasteurized Mexican-style aged cheese contaminated with Salmonella enterica serotype Newport affected eighty-five people and caused thirty-six hospitalizations from March 2006 to April 2007(CDC, 2008). Pasteurization is the first major hurdle in 
the prevention of illness related to cheese products. Removing that hurdle made the product more susceptible to Salmonella contamination and more likely to cause food borne illness. However, Salmonella has also been the cause of outbreaks in pasteurized cheese.

Consumption of contaminated Mozzarella cheese resulted in an outbreak of S. javiana and S. oranienberg infections that affected 139 people (Hedberg et al., 1992). The outbreak resulted from contaminated mozzarella that was produced at a manufacturing plant, and then sent to four separate processing plants for shredding. Contamination of other cheese products occurred at the processing plants during shredding. The presence of Salmonella in a pasteurized cheese product at high enough levels to cause illness emphasizes the importance of the microbial stability of the product formulation. In order to produce a safe product, sufficient microbial hurdles are necessary to reduce microbial populations in the case of pathogenic contamination.

2.2.2.3.3 Staphylococcus aureus. Two separate outbreaks of Staph. aureus have been linked to dishes containing cheese. In 2007, fourteen people fell ill from Staph. aureus isolated from multiple foods at a church and a private home. Another outbreak affecting seventeen people resulted from an Italian restaurant; a cannelloni, containing cheese and chicken, tested positive for Staph. aureus (Anderson et al., 2009). It was found that the dish was not kept at safe food handling temperatures. Again, the ability of Staph. aureus to survive 
and grow in fermented foods, as well as its widespread presence in human hosts, increase the likelihood of its presence in cheeses.

2.2.2.3.4 Listeria monocytogenes. L. monocytogenes outbreaks are of extreme concern to the dairy industry. The organism affects a very sensitive population, has a high mortality rate and is often found in the processing environment. L. monocytogenes has been associated with both pasteurized and unpasteurized cheese products. Two of the largest cases of listeriosis reported were caused by pasteurized dairy products in the early 1980 s.

In 1983, a listeriosis outbreak was associated with the consumption of pasteurized milk (Fleming et al., 1985). A total of forty-nine people were affected and nineteen deaths were reported. In 1985, 142 cases of L. monocytogenes infection were identified in California; twenty-eight deaths were recorded (CDC, 1985). The source of the infection was traced back to Mexican-style cheeses produced by Jalisco Products, Inc. Positive cheese samples all had different expiration dates, suggesting a continuing problem with the manufacturer's cheese products. An investigation of the plant showed that the cheese was commonly contaminated by with unpasteurized milk.

In 2000, L. monocytogenes affected thirteen people in North Carolina (MacDonald et al., 2005); there were no deaths reported. The outbreak was attributed to the consumption of queso fresco cheese made from raw milk and sold by a door-to-door vendor. Another outbreak linked to Mexican-style asadero cheese, made from pasteurized milk, was reported in January of 2009; eight 
cases in five states were identified, but no fatalities were reported (Jackson et al., 2011). A vat gasket was identified as a potential source of contamination of pasteurized milk. However, cheese that was produced after the gasket was removed continued to test positive for $L$. monocytogenes. The sustained presence of the organism indicated more intensive cleaning issues within the plant as well as gasket maintenance issues.

Preventing $L$. monocytogenes from entering and establishing itself in the processing environment is the first step to preventing contamination of finished products. Additionally, plant sanitation and sanitary design of equipment play a role in the safety of cheeses. However, the importance of product formulation cannot be overlooked. Queso fresco and other Mexican-style cheeses are frequently associated with pathogenic contamination due to the lack of microbial hurdles; these cheeses are often formulated with reduced salt content and higher $\mathrm{pH}$ values. By increasing the $\mathrm{pH}$ or substituting the removed salt in order to maintain microbial stability, these products could potentially reduce the risk of contamination.

\subsection{Formulating Reduced Salt Products}

\subsubsection{Salt Replacers}

Reducing salt in cheese affects flavor and shelf stability as well as the enzymatic processes that help develop the texture. In order to successfully achieve a reduction in sodium, a salt replacer that addresses the functional and 
sensory qualities of the cheese needs to be added. However, the research of sodium replacement agents in cheese is limited, mainly focusing on cheddar and feta cheeses. In a study aimed at finding a suitable replacement for salt in cheddar cheese, cheese was produced using $\mathrm{NaCl}$ alone or in combination with either $\mathrm{CaCl}_{2}, \mathrm{KCl}$ or $\mathrm{MgCl}_{2}$, then evaluated by a trained sensory panel (Grummer et al., 2012). Sensory scores of cheddar cheeses made with a combination of $\mathrm{NaCl}$ and $\mathrm{KCl}$ were most similar to cheeses made with $\mathrm{NaCl}$ alone. Cheeses produced with $\mathrm{MgCl}_{2}$ and $\mathrm{CaCl}_{2}$ were positively correlated with bitter, metallic, earthy, unclean and soapy flavors.

$\mathrm{KCl}$ is one of the most widely used salt replacers in the food industry and is generally used to reduce sodium concentrations by $25-50 \%$ (Durack et al., 2008). Studies have shown that, in addition to $\mathrm{KCl}$ maintaining sensory qualities of cheese, using it to replace $\mathrm{NaCl}$ does not affect proteolysis or lipolysis in cheese (Katsiari et al., 2000a; Katsiari et al., 2001a; Katsiari et al., 1997; Katsiari et al., 2000b; Katsiari et al., 2001b). $\mathrm{NaCl}$ and $\mathrm{KCl}$ were used in different ratios $(\mathrm{NaCl}$ contorl, $3: 1 \mathrm{NaCl}: \mathrm{KCl}, 1: 1 \mathrm{NaCl}: \mathrm{KCl}$ ) for brining or dry salting feta and Kefalograviera, a traditional hard Greek cheese. After 180 days storage, the partial replacement of $\mathrm{NaCl}$ by $\mathrm{KCl}$ did not influence the extent and characteristics of proteolysis or lipolysis in feta or Kefalograviera after 240 and 180 days of storage, respectively.

Although previous work has shown that partial replacement with $\mathrm{KCl}$ maintains acceptable flavor, similar studies have not been performed in mozzarella. Intrinsic differences in the formulations could lead to the 
development of undesirable flavors in mozzarella if formulated with $\mathrm{KCl}$. In addition to replacing the flavor in cheeses, the issue of microbial safety needs to be addressed in cheeses with reduced salts.

\subsubsection{Antimicrobial Compounds}

\subsubsection{Potassium Chloride}

In addition to functioning as a sodium replacement agent, $\mathrm{KCl}$ has been studied for its potential antimicrobial efficacy. $\mathrm{KCl}$ functions by reducing the water activity, limiting the available water for microorganism use for metabolic functions and growth. $\mathrm{KCl}$ was just as effective as $\mathrm{NaCl}$ in terms of inactivation and inhibition of the growth of Aeromas hydrophilia, Enterobacter sakazakii, Staphylococcus aureus, Yersinia enterocolitica and Shigella flexneri in TSB when added in the same concentrations, or in concentrations that result in the same water activity of the medium (Bidlas and Lambert, 2008). $\mathrm{NaCl}, \mathrm{KCl}$ and a 55/45 $\mathrm{KCl}: \mathrm{NaCl}$ ratio were added to rennet whey and challenged against $S$. heidelberg and L. monocytogenes (Larson et al., 1993). Alone, or in a 55:45 ratio with $\mathrm{NaCl}$, $\mathrm{KCl}$ was shown to be just as effective at inhibiting the growth of the organisms as $\mathrm{NaCl}$ alone, even though there were no significant differences in water activity.

\subsubsection{Bacteriocins}

Bacteriocins are a group of bioactive peptides, produced by several strains of lactic acid bacteria ( $\mathrm{LAB}$ ) and some propionic bacteria. Bacteriocins 
are widely used in foods for their antimicrobial activity against closely related organisms. Bacteriocins can be added to foods in one of two ways: bacteriocinogenic cultures can be added to the food or used as starter cultures, or food can be supplemented directly with bacteriocins, specifically for the purpose of inhibiting the growth of pathogenic or spoilage microorganisms. Antimicrobial activity of bacteriocins is based on the disruption of the integrity of the cytoplasmic membrane, increasing its permeability (Montville and Chikindas, 2007). This increase in permeability allows the nonspecific influx of ions into the cell. Cells then have to expend energy, in the form of ATP, either to expel the additional ions or to regenerate the proton motive force. The ultimate loss of ATP, due to changes in permeability, leads to microbial growth inhibition and cell death.

Gram-positive organisms are generally more sensitive to the antimicrobial activity of bacteriocins than are Gram-negative organisms. Gram-negative bacteria have an outer membrane that provides resistance to bacteriocins; however, destabilizing the cell surface by physical (freezing or heating) or chemical (chelating agents or high hydrostatic pressure) stresses can render the bacteria sensitive to the action of these antimicrobials (Montville and Chikindas, 2007; Ray and Bhunia, 2008).

Bacteriocins are separated into two groups based on their molecular structures. Class I bacteriocins contain lanthionine rings, and therefore are also known as lantibiotics. Nisin, a lantibiotic produced by Lactococcus lactis subsp. 
lactis, is one of the most well characterized bacteriocins used in the food industry.

The antimicrobial activity of nisin is dependent upon the incubation temperature and $\mathrm{pH}$ of the product; in general, nisin is most effective at lower incubation temperatures and in acidic environments (Montville and Chikindas, 2007). Nisin has varying degrees of efficacy against Gram-negative and Grampositive organisms in dairy products. Nisin exhibited a bacteriostatic effect against Staph. aureus and Salmonella enterica in skim milk refrigerated at $8^{\circ} \mathrm{C}$ for 12 days (Arques et al., 2008b; Arques et al., 2011). Conversely, nisin could not inhibit the growth of E. coli O157:H7 or L. monocytogenes in skim milk during incubation at $8^{\circ} \mathrm{C}$; the organisms grew by $2 \log \mathrm{CFU} / \mathrm{ml}$ and $4.5 \log \mathrm{CFU} / \mathrm{ml}$, respectively, by the end of incubation.

Nisin can work synergistically with other antimicrobials, bacteriocins or chelating agents to inhibit growth or induce death. When combined with lactoperoxidase, nisin exhibited bactericidal effects against $L$. monoctyogenes in Cuajada, a semisolid dairy product (Arques et al., 2008a). L. monocytogenes counts had decreased 4 logs to below detectable levels (detection limit of 1 $\mathrm{CFU} / \mathrm{ml}$ ) after 12 days of incubation at $10^{\circ} \mathrm{C}$. In a broth system, ethylenetriaminetetraacetic acid (EDTA) combined with nisin effectively decreased the counts of Salmonella spp. and E. coli O157:H7 when incubated at $37^{\circ} \mathrm{C}$ for $24 \mathrm{~h}$ (Stevens et al., 1991). Within 60 minutes of treatment, Salmonella counts had decreased by 3.2-5.0 log CFU/ml while E. coli $\mathrm{O} 157: \mathrm{H} 7$ counts had decreased by 6.9 logs. 
The activity of nisin is also highly dependent on the concentration of the bacteriocin; once all of the nisin has been bound, there is none left to further inhibit growth. The addition of nisin, at a concentration of $100 \mathrm{lU} / \mathrm{g}$, initially decreased the count of $L$. monocytogenes in artificially inoculated skim milk incubated at $4^{\circ} \mathrm{C}$ for $24 \mathrm{~h}$ (Zapico et al., 1998). However, after the initial decrease, L. monocytogenes grew by 5 logs CFU/g by the end of incubation. Similarly, in artificially inoculated Anthotyros, a Greek whey cheese, nisin initially decreased the concentration of $L$. monocytogenes by 1 log CFU/g (Samelis et al., 2003). However, after initial reduction, the organism grew more than 4 logs over a 45 day incubation at $4^{\circ} \mathrm{C}$. When the concentration of nisin was increased to $500 \mathrm{IU} / \mathrm{g}$, nisin immediately reduced the concentration of $L$. monocytogenes by $2 \log$ CFU/g in Anthotyros and prevented the growth of the organism for up to 45 days at $4^{\circ} \mathrm{C}$.

Bacteriocins that do not contain lanthionine are grouped in Class II. Class II includes pediocin-like bacteriocins. Pediocins are inactive against bacterial spores, but are capable of inhibiting the growth of vegetative cells. When used in cheese production, pediocin-producing cultures have shown bactericidal activity against Staph. aureus, E. coli O157:H7 and L. monocytogenes during cheese ripening (Rodriguez et al., 2005). Cheese was manufactured from milk artificially inoculated with the pathogenic organisms as well as the pediocin-producing strains. After 30 days of ripening, counts of L. monocytogenes, Staph. aureus and E. coli O157:H7 had decreased by 2.97, 0.98 and $0.84 \log \mathrm{CFU} / \mathrm{g}$, respectively. 


\subsubsection{Organic Acids}

Organic acids can be added to foods to inhibit microbial growth. Antimicrobial effectiveness of organic acids is related to $\mathrm{pH}$ and the acid dissociation constant, or $\mathrm{pK}_{\mathrm{a}}$. The $\mathrm{pK}_{\mathrm{a}}$ is the point at which $50 \%$ of the acid is in the undissociated form. Generally, the undissociated form of the acid is responsible for the antimicrobial effectiveness of organic acids; organic acids are more effective when the majority of the acid is in the undissociated form or when the $\mathrm{pH}<\mathrm{pK}_{\mathrm{a}}$. In the undissociated form, organic acids are able to penetrate the cell membrane. Once inside the cytoplasm, the acids dissociate and generate protons. These protons acidify the cytoplasm and must be expelled to the exterior in order to maintain a near neutral internal $\mathrm{pH}$. Transporting protons requires energy, in the form of ATP and the expulsion of protons eventually results in the depletion of cellular energy (Davidson and Taylor, 2007; Ricke, 2003). Acetic, lactic and propionic acid are the most common organic acids used in dairy products.

Acetic acid $\left(\mathrm{pK}_{\mathrm{a}}=4.75\right)$ and acetates are the primary components of vinegar and are most effective against yeasts and bacteria. Lactic acid $\left(\mathrm{pK}_{\mathrm{a}}=\right.$ 3.79) is produced during fermentation of LAB and acts as an antimicrobial, $\mathrm{pH}$ control agent and flavor enhancer (Davidson and Taylor, 2007). Propionic acid $\left(\mathrm{pK}_{\mathrm{a}}=4.87\right)$ is produced by propionibacterium. The acid and its salts are primarily used against molds, but inhibit the growth of some yeast and bacteria as well. 


\subsubsection{Fermentates}

In addition to organic acids and bacteriocins, fermentates are often used as food antimicrobials. Fermentates are products of in situ controlled acidification by LAB; typically, the fermentation produces organic acids, low molecular weight proteins and other antimicrobial components, such as diacetyl (Montville and Chikindas, 2007). The efficacy of fermentates is determined by the initial $\mathrm{pH}$ and buffering capacity of the product, characteristics of target microorganisms, type of fermentable carbohydrates, and the growth rates of the $\mathrm{LAB}$ and target pathogens at refrigerated and abuse temperatures. Microgard, a cultured milk product produced through the fermentation of milk by Propionibacterium shermanii, is a GRAS food preservative; fermentation produces acetate, propionic acid and low molecular weight proteins.

Microgard products are commercially available and claim to inhibit the growth of Gram-negative and Gram-positive organisms. However, studies have shown that the efficacy of Microgard against Gram-positive organisms is dependent on the product. In hamburger, Microgard products were able to reduce the counts of $E$. coli O157:H7, but could not inhibit the growth of $L$. monocytogenes (Dave et al., 2003). Additionally, Microgard products could not inhibit the growth of $L$. innocua in liquid cheese whey (Staszewski and Jagus, 2008). Though Microgard products possess a bacteriocin, the main antimicrobial activity comes from the propionic acid, rendering its activity dependent upon the $\mathrm{pH}$ of the food matrix (Montville and Chikindas, 2007). 


\subsubsection{Glucose Oxidase}

Glucose oxidase (GO) is a non-hydrolytic enzyme that has several applications in the beverage, pharmaceutical and food industries (Bankar et al., 2009). GO is used in the wine industry for its bactericidal activity against acetic and lactic acid bacteria; adding GO prevents the growth of spoilage bacteria and allows the use of fewer preservatives in wine. It is also added to remove glucose from dried egg, removes oxygen from fruit juices and canned beverages, and improves the color, flavor and shelf life of foods (Bankar et al., 2009; Hatzinikolaou and Macris, 1995). The most common sources for the fermentative production of GO are Aspergillus, Penicillium, and Saccharomyces species (Bankar et al., 2009). GO uses molecular oxygen to catalyze the oxidation of $\beta$-D-glucose to gluconic acid and hydrogen peroxide $\left(\mathrm{H}_{2} \mathrm{O}_{2}\right.$; Figure 2.2).

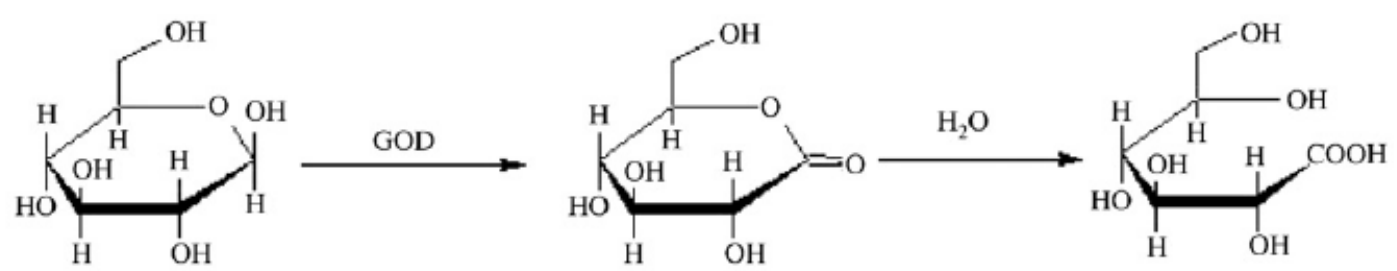

$\beta$ - D glucose

D - glucono - $\delta$ - lactone

Gluconic acid

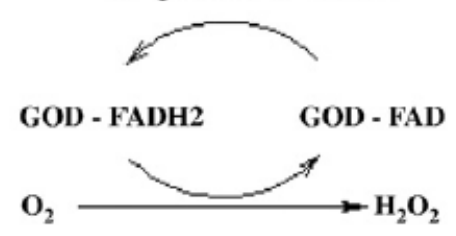

Figure 2.2 Representation of the glucose oxidase reaction.

Source: Bankar, S. B., Bule, M. V., Singhal, R. S., \& Ananthanarayan, L. (2009). Glucose oxidase - An overview. Biotechnology Advances, 27(4), 489-501. 
GO has several antimicrobial applications involving the removal of residual glucose and oxygen in order to prolong the shelf life of foods. Enzyme activity is dependent on the $\mathrm{pH}$ and optimum temperature. The optimum $\mathrm{pH}$ of $\mathrm{GO}$ ranges from 5.0 to 7.0 , while the temperature optimum ranges from $25^{\circ}-60^{\circ} \mathrm{C}$.

Additionally, the $\mathrm{H}_{2} \mathrm{O}_{2}$ produced by the enzyme acts an effective bactericide. The antimicrobial action of $\mathrm{H}_{2} \mathrm{O}_{2}$ is based on its strong oxidizing property and its ability to damage cellular components (Imlay and Linn, 1988; Ray and Bhunia, 2008). $\mathrm{H}_{2} \mathrm{O}_{2}$ has been used as an antimicrobial wash in fresh fruits and vegetables. It was able to decrease the counts of Salmonella spp. in artificially inoculated whole and fresh cut pieces of cantaloupe and honeydew melons (Ukuku, 2004). Organism populations were reduced by 2.5 and $3 \mathrm{log} C F U / g$ in whole cantaloupe and honeydew melons, respectively, after $\mathrm{H}_{2} \mathrm{O}_{2}$ washing treatments. Additionally, $\mathrm{H}_{2} \mathrm{O}_{2}$ can be used in combination with lactoperoxidase, forming the antimicrobial lactoperoxidase system (discussed further below).

\subsubsection{Lactoperoxidase}

Lactoperoxidase is a glycoprotein enzyme that is found in raw milk, colostrum and other biological secretions. It belongs to the peroxidase family, a group of natural enzymes widely distributed in nature and found in plants and animals; lactoperoxidase catalyzes the peroxidation of thiocyanates to generate products that kill or inhibit the growth of many microorganisms (Kussendrager and van Hooijdonk, 2000). It reacts with thiocyanate in the presence of hydrogen peroxide in order to form antimicrobial compounds; this reaction is termed the 
lactoperoxidase system (LPS). The thiocyanate ion oxidizes sulfhydryl groups to disulfides, sulfenylthiocyanates, or sulfenic acid. The reaction of thiocyanate with $\mathrm{NADH}$ or interference with membrane proteins may cause leakage of the membrane or the loss of electrochemical potential, eventually leading to the inhibition of the transport of amino acids and sugars (Davidson and Taylor, 2007).

Hydrogen peroxide is necessary for the LPS to function as an antimicrobial. It can be added to foods through the addition of hydrogen peroxide producing lactic acid bacteria (Ito et al, 2003) or by the enzymatic action of glucose oxidase. The LPS is active against both Gram-negative and Grampositive bacteria, but different groups of bacteria have different levels of resistance to the LPS (Kussendrager and van Hooijdonk, 2000). Antimicrobial reaction mechanisms of LPS are complex and their effectiveness depends on the intrinsic properties of the medium $(\mathrm{pH}$, temperature, incubation time, cell density, etc.). The LPS was bactericidal to Salmonella and was shown to inhibit the growth of E. coli O157:H7 and L. monoctygenes in milk when incubated at $4^{\circ} \mathrm{C}$ (Arques et al., 2008b; Zapico et al., 1998).

Commercially available SEA-i F75 contains lactoperoxidase and glucose oxidase. Glucose oxidase functions to produce hydrogen peroxide, while the halide or thiocyanate must be present in the food matrix for the enzyme system to function properly. 


\subsubsection{Lysozyme}

Lysozyme is an enzyme found in avian eggs, milk, insects, fish and some plant tissues. Dried egg whites are the primary commercial source of lysozyme for foods (Davidson and Taylor, 2007). The enzyme is relatively heat stable, with functionality at temperatures up to $100^{\circ} \mathrm{C}$, but the enzyme's optimum functionality is at temperatures between 55 and $60^{\circ} \mathrm{C}$ at pH values of 6.0 and 7.0 . Lysozyme is most active against Gram-positive bacteria because the target of its antimicrobial action is the peptidoglycan of the cell wall; the enzyme works by catalyzing the hydrolysis of the $\alpha-1,4$ glycosidic bonds between $N$-acetylmuramic acid and $\mathrm{N}$-acetylglucosamine of the peptidoglycan in cell walls, causing cell degradation and lysis (Davidson and Taylor, 2007). Ibrahim, Matsuzaki, \& Aoki (2001) found that the bactericidal activity of lysozyme is independent of the enzyme's catalytic activity. Results suggest that there are two modes of catalytically independent bactericidal action: 1) an indirect bacteriolyticdependent mode and 2) a lysis-dependent mode that involves the regulation of cell wall-associated autolysins.

Lysozyme is highly effective against $L$. monocytogenes strains. Hughey \& Johnson (1987) showed that four strains of $L$. monocytogenes isolates from food poisoning outbreaks were extremely susceptible to the activity of lysozyme. Up to $80 \%$ of cells suspended in phosphate buffer, incubated at $4^{\circ} \mathrm{C}$ and treated with lysozyme (100 mg/liter) were lysed after $6 \mathrm{~h}$ of incubation. Gram-negative cell susceptibility to lysozyme can be increased through the initial destabilization of the outer membrane by chemical (i.e. EDTA) or physical (i.e. freezing) means 
(Branen and Davidson, 2004; Ray and Bhunia, 2008). The food type, as well as processing and storage conditions, influences the antimicrobial activity of lysozyme.

\subsubsection{Lauric Arginate}

Lauric arginate (LAE) is a cationic preservative derived from lauric acid and arginine. LAE also acts as a surfactant. Surfactants possess antimicrobial activity due to their chemical properties; surfactants reduce the surface tension and the formation of ionic aggregates which leads to changes in conductivity and the solubility of solutions (Rodriguez et al., 2004). In Gram-negative cells, LAE works by altering the cytoplasmic membrane and the external membrane while in Gram-positive cells, the surfactant works by altering the cell membrane and cytoplasm (Rodriguez et al., 2004). Though the cells do not lyse, these alterations disrupt the membrane causing ion leakage and a loss of cell viability.

Rodriguez, et al. (2004) examined the effects of LAE on S. Typhimurium and Staphylococcus aureus using transmission electron microscopy (TEM). LAE initially induced severe damage of the $S$. Typhimurium bacterial membranes; an increase of damage was observed after $24 \mathrm{~h}$. The membrane of Staph. aureus was also severely damaged by the activity of the LAE, however, damage of the membrane progressed much more slowly. LAE initially reduced the populations of $L$. monocytogenes by up to $2 \mathrm{log} \mathrm{CFU} / \mathrm{ml}$ in milk and queso fresco cheese (QFC) when incubated at $4^{\circ} \mathrm{C}$ (Soni et al., 2010). However, there was no 
subsequent inhibitory effect by LAE; growth resume slowly during long-term storage of QFC at $4^{\circ} \mathrm{C}$.

\subsection{Conclusion}

Cheese consumption has been on the rise over the last decade. Cheese is highly nutritious, providing both calcium and protein, but is also perceived as being high in sodium. Unfortunately, excessive dietary sodium has several detrimental effects on cardiovascular health. The negative health effects of excessive dietary sodium and consumers' desire for products with reduced sodium have encouraged food manufacturers to reduce sodium in processed foods (Larson et al., 1993). However, there are several challenges to overcome when reducing sodium.

Studies have shown that pathogens have the ability to survive and/or grow in cheeses. Decreasing sodium would diminish the major microbial hurdle in cheeses and could make cheeses more susceptible to pathogenic growth if contaminated. In order to remove the sodium in cheese and avoid unfavorable changes to the product, salt replacers and antimicrobials may be a necessary addition to ensure product safety and consumer acceptability. This study examines the antimicrobial efficacy of several antimicrobials and salt substitutes in agar and cheese systems with the intent of finding a suitable antimicrobial for use in low sodium low-moisture part-skim mozzarella cheese. 


\subsection{Antimicrobial Efficacy Screening in TSA}

\subsection{Objectives}

To determine the antimicrobial efficacy of commercially available antimicrobials and sodium replacement agents in tryptic soy agar (TSA).

\subsection{Hypothesis}

Antimicrobials and sodium replacement agents will inhibit the growth of Salmonella, Listeria monocytogenes and E. coli O157:H7.

\subsection{Materials and Methods}

\subsubsection{Bacterial Strains}

Five strains of each E. coli O157:H7, Listeria monocytogenes and Salmonella were used in the study. E. coli O157:H7 strains NFPA 4212, NFPA 4213, NFPA 4216, NFPA 4217, and NFPA 4219 were obtained from the culture collection of the National Food Laboratory (Livermore, CA). Two of the Listeria monocytogenes strains, NFPA 6301 and NFPA 6306, were obtained from the culture collection of the National Food Laboratory (Livermore, CA) while the other

three strains, NRRL B-33000, NRRL B-33096, and NRRL B-33113 were received from the National Center for Agricultural Utilization Research (Peoria, IL). Salmonella enterica strains, Salmonella Javiana FSL S5-406, Salmonella Enteriditis FSL S5-415, Salmonella Heidelburg FSL S5-448, Salmonella 
Oranienburg FSL S5-642, and Salmonella Typhimurium FSL W1-030, were obtained from the International Life Sciences Institute, North America (Cornell University, Ithaca, NY).

All strains were stored in cryogenic vials (Fisher Scientific, Hanover Park, IL) at $-70^{\circ} \mathrm{C}$ for long-term preservation. Prior to use, cultures were streaked on selective media and incubated at $35^{\circ} \mathrm{C}$ for $24 \mathrm{~h}$. Salmonella strains were streaked on Xylose Lysine Deoxycholate Agar (XLD, Neogen, Lansing, MI), while Modified Oxford Agar (MOX, Difco, Sparks, MD) was used for Listeria monocytogenes and MacConkey Agar with Sorbitol (SMAC, Neogen, Lansing, MI) was used for E. coli O157:H7. Isolated colonies were used for inoculum preparation.

\subsubsection{Preparation of Inocula}

Each strain was individually transferred into $10 \mathrm{ml}$ of Tryptic Soy Broth (TSB, Neogen, Lansing, MI) and grown at $35^{\circ} \mathrm{C}$ for $18 \mathrm{~h}$. After incubation, equal volumes of each strain were pooled within a species to form a cocktail. Each cocktail was centrifuged (1,800 $\mathrm{g} \times 15 \mathrm{~min})$, washed twice with $0.1 \%$ peptone water and resuspended in $0.1 \%$ peptone water. Direct microscope count (DMC) was done with a Petroff-Hausser Counting Chamber (Hausser Scientific, Horsham, PA) to determine the initial stock concentration. Cocktails were diluted to the target concentration using $0.1 \%$ peptone water. Initial counts were confirmed by plating on Tryptic Soy Agar (TSA, Neogen, Lansing, MI) and incubating at $35^{\circ} \mathrm{C}$ for $24 \mathrm{~h}$. 


\subsubsection{Antimicrobials and Sodium Replacement Agents}

Eight antimicrobials received from several suppliers were used in the study, and consisted of MicroGard 100, MicroGard 430, Nisaplin, NovaGard CB1, Protect-M, PuraQ Verdad RV 75, SEA-i F75 and VMY1P (Table 3.1). Six sodium replacement agents received from several suppliers were also used in the study, and included potassium chloride, Puracal PP/USP, PuraQ Verdad NV10, Purasal Hi Pure P Plus, SaltWise 0029 and SaltWise 1029 (Table 3.2). Antimicrobials and sodium replacement agents were stored per manufacturer's recommendation until used in the study.

\subsubsection{Antimicrobial Efficacy Determination}

Antimicrobial efficacy experiments were performed in duplicate. The efficacy of the antimicrobials was determined using an agar dilution method (Oussalah et al., 2007b). TSA was adjusted to $\mathrm{pH} 5.8$, using $1 \mathrm{~N} \mathrm{HCl}$, to mimic typical $\mathrm{pH}$ conditions of mozzarella cheese. After $\mathrm{pH}$ adjustment, antimicrobials or sodium replacement agents were added to agar at various concentrations (Tables 3.1 and 3.2). Concentrations used for each antimicrobial and sodium replacement agent were determined using manufacturer recommendations. The supplemented agars were poured into sterile petri plates and allowed to solidify. Salmonella, L. monocytogenes or E. coli O157:H7 was spread plated onto solidified TSA at a target concentration of $10^{1}, 10^{2}$ and $10^{4} \mathrm{CFU} / \mathrm{ml}$. Uninoculated TSA plates served as negative controls while inoculated plates, without antimicrobial added, served as positive controls. Uninoculated 
supplemented agar plates were also tested for $\mathrm{pH}$. All test and control plates were incubated at $35^{\circ} \mathrm{C}$ for $48 \mathrm{~h}$. Plates were observed after $24 \mathrm{~h}$ and $48 \mathrm{~h}$ for presence or absence of growth. For all plates, absence of growth indicated the antimicrobial had an inhibitory effect.

Table 3.1 Description and concentrations of antimicrobials used to determine antimicrobial efficacy in tryptic soy agar (TSA) screening.

\begin{tabular}{|c|c|c|c|c|c|c|}
\hline Antimicrobial & Manufacturer & Product Description & \multicolumn{4}{|c|}{ Concentrations Used (\%) } \\
\hline MicroGard 100 & Danisco & $\begin{array}{l}\text { Cultured Grade A Nonfat Dry Milk } \\
\text { Powder; Diacetyl; Organic Acids }\end{array}$ & 0.5 & 0.75 & 1.0 & 2.0 \\
\hline MicroGard 430 & Danisco & $\begin{array}{c}\text { Cultured Grade A Nonfat Dry Milk } \\
\text { Powder; Maltodextrin; Diacetyl; Organic } \\
\text { Acids }\end{array}$ & 0.5 & 0.75 & 1.0 & 2.0 \\
\hline Nisaplin & Danisco & Nisin; $\mathrm{NaCl}$ & 0.03 & 0.05 & 0.10 & \\
\hline $\begin{array}{l}\text { NovaGard } \\
\text { CB1 }\end{array}$ & Danisco & $\begin{array}{l}\text { Maltodextrin; Cultured Dextrose; Sodium } \\
\text { Diacetate; NaCl; Lysozyme; Nisin }\end{array}$ & 0.5 & 0.75 & 1.0 & 2.0 \\
\hline Protect-M & Purac & Lauric Arginate & 0.10 & 0.15 & 0.20 & 0.40 \\
\hline $\begin{array}{l}\text { PuraQ Verdad } \\
\text { RV75 }\end{array}$ & Purac & $\begin{array}{c}\text { Cultured Sugar; Organic Acids; Residual } \\
\text { Sugars }\end{array}$ & 0.1 & 0.2 & 0.4 & \\
\hline SEA-i F75 & Bienca & $\begin{array}{l}\text { Glucose; Glucose Oxidase; Whey; } \\
\text { Lactoperoxidase; Lactose; Casein }\end{array}$ & 0.25 & 0.50 & & \\
\hline VMY1P & Purac & Cultured Whey & 0.5 & 0.75 & 1.0 & \\
\hline
\end{tabular}


Table 3.2 Description and concentrations of sodium replacement agents used to determine antimicrobial efficacy in tryptic soy agar (TSA).

\begin{tabular}{|c|c|c|c|c|c|}
\hline $\begin{array}{l}\text { Sodium Replacement } \\
\text { Agents }\end{array}$ & Manufacturer & Product Description & \multicolumn{3}{|c|}{$\begin{array}{c}\text { Concentrations Used } \\
(\%)\end{array}$} \\
\hline Potassium Chloride & Cargill & Potassium chloride & 1.0 & 2.0 & \\
\hline Puracal PP/USP & Purac & Calcium lactate & 0.02 & 0.04 & \\
\hline $\begin{array}{l}\text { Puracal Hi Pure P } \\
\text { Plus }\end{array}$ & Purac & Potassium lactate & 0.02 & 0.04 & \\
\hline PuraQ Verdad NV10 & Purac & Cultured corn sugar & 0.02 & 0.04 & \\
\hline SaltWise 0029 & Cargill & $\begin{array}{l}\text { Potassium chloride; trehalose; } \\
\text { autolyzed yeast extract; silicon } \\
\text { dioxide }\end{array}$ & 0.5 & 1.0 & 2.0 \\
\hline SaltWise 1029 & Cargill & $\begin{array}{l}\text { Potassium chloride; trehalose; } \\
\text { autolyzed yeast extract; silicon } \\
\text { dioxide }\end{array}$ & 0.5 & 1.0 & 2.0 \\
\hline
\end{tabular}

\subsection{Results}

\subsubsection{Efficacy of antimicrobials against Salmonella, E. coli 0157:H7 and $L$. monocytogenes in TSA}

MicroGard 100, Nisaplin and VMY1P did not inhibit the growth of any of the organisms tested at any of the inoculum levels tested (Tables 3.3, 3.5 and 3.10). Growth of Salmonella and E. coli O157:H7 was detected after $24 \mathrm{~h}$ of incubation in TSA supplemented with MicroGard 430 (Table 3.4). However, at a concentration of $2.0 \%$, MicroGard 430 delayed the growth of L. monocytogenes at inoculum levels of $10^{1}$ and $10^{2} \mathrm{CFU} / \mathrm{ml}$. NovaGard CB1 at concentrations 
less than $2.0 \%$ could not inhibit the growth of Salmonella, E. coli $\mathrm{O} 157: \mathrm{H} 7$ or $\mathrm{L}$. monocytognes (Table 3.6). At a concentration of 2.0\%, NovaGard CB1 delayed the growth of all three organisms at all inoculum levels tested. Protect-M and SEA-i F75 completely inhibited all three organisms tested at all inoculum levels and all antimicrobial concentrations (Tables 3.7 and 3.9). PuraQ Verdad RV75 at a concentration of $0.1 \%$ could not inhibit the growth of E. coli $\mathrm{O} 157: \mathrm{H} 7$, Salmonella, or L. monocytogenes in TSA (Table 3.8). At a concentration of $0.2 \%$, growth of $E$. coli $\mathrm{O} 157: \mathrm{H} 7$ and the highest inoculum level of Salmonella were not inhibited, while the growth of the lowest inoculum levels of Salmonella and all levels $L$. monocytogenes were partially inhibited by PuraQ Verdad RV75 in TSA.

Table 3.3 Growth of Salmonella and E. coli 0157:H7 on TSA (pH 5.8) supplemented with MicroGard $100^{1}$ and incubated at $35^{\circ} \mathrm{C}$.

\begin{tabular}{|c|c|c|c|}
\hline \multirow{2}{*}{$\begin{array}{l}\text { Antimicrobial } \\
\text { Concentration }\end{array}$} & \multirow{2}{*}{$\begin{array}{c}\text { Target Organism } \\
\text { Concentration (CFU/ml) }\end{array}$} & \multicolumn{2}{|c|}{ Time Until Observed Organism Growth } \\
\hline & & Salmonella & E. coli $0157: \mathrm{H} 7$ \\
\hline \multirow{3}{*}{$\begin{array}{c}0.5 \% \\
(\mathrm{pH} 5.92)\end{array}$} & $5.0 \times 10^{1}$ & $24 \mathrm{~h}$ & $24 \mathrm{~h}$ \\
\hline & $5.0 \times 10^{2}$ & $24 \mathrm{~h}$ & $24 \mathrm{~h}$ \\
\hline & $5.0 \times 10^{4}$ & $24 \mathrm{~h}$ & $24 \mathrm{~h}$ \\
\hline \multirow{3}{*}{$\begin{array}{c}0.75 \% \\
(\mathrm{pH} 5.81)\end{array}$} & $5.0 \times 10^{1}$ & $24 \mathrm{~h}$ & $24 \mathrm{~h}$ \\
\hline & $5.0 \times 10^{2}$ & $24 \mathrm{~h}$ & $24 \mathrm{~h}$ \\
\hline & $5.0 \times 10^{4}$ & $24 \mathrm{~h}$ & $24 \mathrm{~h}$ \\
\hline \multirow{3}{*}{$\begin{array}{c}1.0 \% \\
(\mathrm{pH} 5.78)\end{array}$} & $5.0 \times 10^{1}$ & $24 \mathrm{~h}$ & $24 \mathrm{~h}$ \\
\hline & $5.0 \times 10^{2}$ & $24 \mathrm{~h}$ & $24 \mathrm{~h}$ \\
\hline & $5.0 \times 10^{4}$ & $24 \mathrm{~h}$ & $24 \mathrm{~h}$ \\
\hline \multirow{3}{*}{$\begin{array}{c}2.0 \% \\
(\mathrm{pH} \mathrm{5.64)}\end{array}$} & $5.0 \times 10^{1}$ & $24 \mathrm{~h}$ & $24 \mathrm{~h}$ \\
\hline & $5.0 \times 10^{2}$ & $24 \mathrm{~h}$ & $24 \mathrm{~h}$ \\
\hline & $5.0 \times 10^{4}$ & $24 \mathrm{~h}$ & $24 \mathrm{~h}$ \\
\hline
\end{tabular}


Table 3.4 Growth of Salmonella, E. coli 0157:H7 and L. monocytogenes on TSA (pH 5.8) supplemented with MicroGard 430 and incubated at $35^{\circ} \mathrm{C}$.

\begin{tabular}{ccccc}
\hline $\begin{array}{c}\text { Antimicrobial } \\
\text { Concentration }\end{array}$ & $\begin{array}{c}\text { Target Organism } \\
\text { Concentration } \\
\text { (CFU/ml) }\end{array}$ & \multicolumn{3}{c}{ Time Until Observed Organism Growth } \\
& & Salmonella & E. coli O157:H7 & L. monocytogenes \\
\hline $0.50 \%$ & $5.0 \times 10^{1}$ & $24 \mathrm{~h}$ & $24 \mathrm{~h}$ & $24 \mathrm{~h}$ \\
$(\mathrm{pH} \mathrm{6.05)}$ & $5.0 \times 10^{2}$ & $24 \mathrm{~h}$ & $24 \mathrm{~h}$ & $24 \mathrm{~h}$ \\
& $5.0 \times 10^{4}$ & $24 \mathrm{~h}$ & $24 \mathrm{~h}$ & $24 \mathrm{~h}$ \\
& & & & \\
$0.75 \%$ & $5.0 \times 10^{1}$ & $24 \mathrm{~h}$ & $24 \mathrm{~h}$ & $24 \mathrm{~h}$ \\
$(\mathrm{pH} \mathrm{5.82)}$ & $5.0 \times 10^{2}$ & $24 \mathrm{~h}$ & $24 \mathrm{~h}$ & $24 \mathrm{~h}$ \\
& $5.0 \times 10^{4}$ & $24 \mathrm{~h}$ & $24 \mathrm{~h}$ & $24 \mathrm{~h}$ \\
$1.0 \%$ & & & & \\
$(\mathrm{pH} \mathrm{5.45)}$ & $5.0 \times 10^{1}$ & $24 \mathrm{~h}$ & $24 \mathrm{~h}$ & $24 \mathrm{~h}$ \\
& $5.0 \times 10^{2}$ & $24 \mathrm{~h}$ & $24 \mathrm{~h}$ & $24 \mathrm{~h}$ \\
$2.0 \%$ & $5.0 \times 10^{4}$ & $24 \mathrm{~h}$ & $24 \mathrm{~h}$ & $24 \mathrm{~h}$ \\
$(\mathrm{pH} \mathrm{5.02)}$ & $5.0 \times 10^{1}$ & $24 \mathrm{~h}$ & $24 \mathrm{~h}$ & $48 \mathrm{~h}$ \\
& $5.0 \times 10^{2}$ & $24 \mathrm{~h}$ & $24 \mathrm{~h}$ & $48 \mathrm{~h}$ \\
& $5.0 \times 10^{4}$ & $24 \mathrm{~h}$ & $24 \mathrm{~h}$ & $24 \mathrm{~h}$ \\
\hline
\end{tabular}

Table 3.5 Growth of Listeria monocytogenes on TSA (pH 5.8) supplemented with Nisaplin and incubated at $35^{\circ} \mathrm{C}$.

Antimicrobial
Concentration Target Organism Concentration (CFU/ml) Time Until Observed Organism Growth

$\begin{array}{cll}0.03 \% & 5.0 \times 10^{1} & 24 \mathrm{~h} \\ (\mathrm{pH} \mathrm{5.84)} & 5.0 \times 10^{2} & 24 \mathrm{~h} \\ & 5.0 \times 10^{4} & 24 \mathrm{~h} \\ & & \\ 0.05 \% & 5.0 \times 10^{1} & 24 \mathrm{~h} \\ (\mathrm{pH} \mathrm{5.82)} & 5.0 \times 10^{2} & 24 \mathrm{~h} \\ & 5.0 \times 10^{4} & 24 \mathrm{~h} \\ 0.10 \% & & \\ (\mathrm{pH} \mathrm{5.79)} & 5.0 \times 10^{1} & 24 \mathrm{~h} \\ & 5.0 \times 10^{2} & 24 \mathrm{~h} \\ & 5.0 \times 10^{4} & 24 \mathrm{~h}\end{array}$


Table 3.6 Growth of Salmonella, E. coli 0157:H7 and L. monocytogenes on TSA (pH 5.8) supplemented with NovaGard CB1 and incubated at $35^{\circ} \mathrm{C}$.

\begin{tabular}{ccccc}
\hline $\begin{array}{c}\text { Antimicrobial } \\
\text { Concentration }\end{array}$ & $\begin{array}{c}\text { Target Organism } \\
\text { Concentration } \\
\text { (CFU/ml) }\end{array}$ & \multicolumn{3}{c}{ Time Until Observed Organism Growth } \\
& & Salmonella & E. coli O157:H7 & L. monocytogenes \\
\hline $0.50 \%$ & $5.0 \times 10^{1}$ & $24 \mathrm{~h}$ & $24 \mathrm{~h}$ & $24 \mathrm{~h}$ \\
$(\mathrm{pH} \mathrm{5.97)}$ & $5.0 \times 10^{2}$ & $24 \mathrm{~h}$ & $24 \mathrm{~h}$ & $24 \mathrm{~h}$ \\
& $5.0 \times 10^{4}$ & $24 \mathrm{~h}$ & $24 \mathrm{~h}$ & $24 \mathrm{~h}$ \\
$0.75 \%$ & $5.0 \times 10^{1}$ & $24 \mathrm{~h}$ & $24 \mathrm{~h}$ & $24 \mathrm{~h}$ \\
$(\mathrm{pH} \mathrm{5.84)}$ & $5.0 \times 10^{2}$ & $24 \mathrm{~h}$ & $24 \mathrm{~h}$ & $24 \mathrm{~h}$ \\
& $5.0 \times 10^{4}$ & $24 \mathrm{~h}$ & $24 \mathrm{~h}$ & $24 \mathrm{~h}$ \\
$1.0 \%$ & & & & \\
$(\mathrm{pH} \mathrm{5.76)}$ & $5.0 \times 10^{1}$ & $24 \mathrm{~h}$ & $24 \mathrm{~h}$ & $24 \mathrm{~h}$ \\
& $5.0 \times 10^{2}$ & $24 \mathrm{~h}$ & $24 \mathrm{~h}$ & $24 \mathrm{~h}$ \\
$2.0 \%$ & $5.0 \times 10^{4}$ & $24 \mathrm{~h}$ & $24 \mathrm{~h}$ & $24 \mathrm{~h}$ \\
$(\mathrm{pH} \mathrm{5.36)}$ & $5.0 \times 10^{1}$ & $48 \mathrm{~h}$ & $48 \mathrm{~h}$ & $48 \mathrm{~h}$ \\
& $5.0 \times 10^{2}$ & $48 \mathrm{~h}$ & $48 \mathrm{~h}$ & $48 \mathrm{~h}$ \\
& $5.0 \times 10^{4}$ & $48 \mathrm{~h}$ & $48 \mathrm{~h}$ & $48 \mathrm{~h}$ \\
\hline
\end{tabular}

Table 3.7 Growth of Salmonella, E. coli 0157:H7 and L. monocytogenes on TSA (pH 5.8) supplemented with Protect-M and incubated at $35^{\circ} \mathrm{C}$.

\begin{tabular}{|c|c|c|c|c|}
\hline \multirow{2}{*}{$\begin{array}{l}\text { Antimicrobial } \\
\text { Concentration }\end{array}$} & \multirow{2}{*}{$\begin{array}{l}\text { Target Organism } \\
\text { Concentration } \\
\text { (CFU/ml) }\end{array}$} & \multicolumn{3}{|c|}{ Time Until Observed Organism Growth } \\
\hline & & Salmonella & E. coli 0157:H7 & L. monocytogenes \\
\hline \multirow{3}{*}{$\begin{array}{c}0.10 \% \\
(\mathrm{pH} 5.81)\end{array}$} & $5.0 \times 10^{1}$ & NG1 & NG & NG \\
\hline & $5.0 \times 10^{2}$ & NG & NG & NG \\
\hline & $5.0 \times 10^{4}$ & NG & NG & NG \\
\hline \multirow{3}{*}{$\begin{array}{c}0.15 \% \\
(\mathrm{pH} 5.78)\end{array}$} & $5.0 \times 10^{1}$ & NG & NG & NG \\
\hline & $5.0 \times 10^{2}$ & NG & NG & NG \\
\hline & $5.0 \times 10^{4}$ & NG & NG & NG \\
\hline \multirow{3}{*}{$\begin{array}{c}0.20 \% \\
(\mathrm{pH} 5.71)\end{array}$} & $5.0 \times 10^{1}$ & NG & NG & NG \\
\hline & $5.0 \times 10^{2}$ & NG & NG & NG \\
\hline & $5.0 \times 10^{4}$ & NG & NG & NG \\
\hline \multirow{3}{*}{$\begin{array}{c}0.40 \% \\
(\mathrm{pH} 5.71)\end{array}$} & $5.0 \times 10^{1}$ & NG & NG & NG \\
\hline & $5.0 \times 10^{2}$ & NG & NG & NG \\
\hline & $5.0 \times 10^{4}$ & NG & NG & NG \\
\hline
\end{tabular}

${ }^{1} \mathrm{NG}$ : No growth detected after 48 hours of incubation at $35^{\circ} \mathrm{C}$. 
Table 3.8 Growth of Salmonella, E. coli 0157:H7 and L. monocytogenes on TSA (pH 5.8) supplemented with PuraQ Verdad RV75 and incubated at $35^{\circ} \mathrm{C}$.

\begin{tabular}{ccccc}
\hline $\begin{array}{c}\text { Antimicrobial } \\
\text { Concentration }\end{array}$ & $\begin{array}{c}\text { Target Organism } \\
\text { Concentration } \\
\text { (CFU/ml) }\end{array}$ & Salmonella & E. coli O157:H7 & L. monocytogenes \\
\hline & $5.0 \times 10^{1}$ & $24 \mathrm{~h}$ & $24 \mathrm{~h}$ & $24 \mathrm{~h}$ \\
$0.1 \%$ & $5.0 \times 10^{2}$ & $24 \mathrm{~h}$ & $24 \mathrm{~h}$ & $24 \mathrm{~h}$ \\
$(\mathrm{pH} \mathrm{5.83)}$ & $5.0 \times 10^{4}$ & $24 \mathrm{~h}$ & $24 \mathrm{~h}$ & $24 \mathrm{~h}$ \\
& & & & \\
$0.2 \%$ & $5.0 \times 10^{1}$ & $48 \mathrm{~h}$ & $24 \mathrm{~h}$ & $48 \mathrm{~h}$ \\
$(\mathrm{pH} \mathrm{5.77)}$ & $5.0 \times 10^{2}$ & $24 \mathrm{~h}$ & $24 \mathrm{~h}$ & $48 \mathrm{~h}$ \\
& $5.0 \times 10^{4}$ & $24 \mathrm{~h}$ & $24 \mathrm{~h}$ & $48 \mathrm{~h}$ \\
$0.4 \%$ & $5.0 \times 10^{1}$ & & & \\
$(\mathrm{pH} \mathrm{5.60)}$ & $5.0 \times 10^{2}$ & $48 \mathrm{~h}$ & $\mathrm{NG}$ & $\mathrm{NG}$ \\
& $5.0 \times 10^{4}$ & $48 \mathrm{~h}$ & $48 \mathrm{~h}$ & $\mathrm{NG}$ \\
\hline
\end{tabular}

${ }^{1} \mathrm{NG}$ : No growth detected after 48 hours of incubation at $35^{\circ} \mathrm{C}$.

Table 3.9 Growth of Salmonella, E. coli 0157:H7 and L. monocytogenes on TSA (pH 5.8) supplemented with SEA-i F75 and incubated at $35^{\circ} \mathrm{C}$.

\begin{tabular}{ccccc}
\hline $\begin{array}{c}\text { Antimicrobial } \\
\text { Concentration }\end{array}$ & $\begin{array}{c}\text { Target Organism } \\
\text { Concentration } \\
\text { (CFU/ml) }\end{array}$ & $\begin{array}{c}\text { Time Until Observed Organism Growth } \\
\text { Salmonella }\end{array}$ & E. coli O157:H7 & L. monocytogenes \\
\hline $0.25 \%$ & $5.0 \times 10^{1}$ & NG 1 & NG & NG \\
$(\mathrm{pH} \mathrm{5.82)}$ & $5.0 \times 10^{2}$ & $\mathrm{NG}$ & $\mathrm{NG}$ & $\mathrm{NG}$ \\
& $5.0 \times 10^{4}$ & $\mathrm{NG}$ & $\mathrm{NG}$ & $\mathrm{NG}$ \\
$0.50 \%$ & $5.0 \times 10^{1}$ & $\mathrm{NG}$ & $\mathrm{NG}$ & $\mathrm{NG}$ \\
$(\mathrm{pH} \mathrm{5.44)}$ & $5.0 \times 10^{2}$ & $\mathrm{NG}$ & $\mathrm{NG}$ & $\mathrm{NG}$ \\
& $5.0 \times 10^{4}$ & $\mathrm{NG}$ & $\mathrm{NG}$ & $\mathrm{NG}$ \\
\hline
\end{tabular}

${ }^{1} \mathrm{NG}$ : No growth detected after 48 hours of incubation at $35^{\circ} \mathrm{C}$. 
Table 3.10 Growth of Salmonella, E. coli 0157:H7 and L. monocytogenes on TSA (pH 5.8) supplemented with VMY1P and incubated at $35^{\circ} \mathrm{C}$.

\begin{tabular}{ccccc}
\hline $\begin{array}{c}\text { Antimicrobial } \\
\text { Concentration }\end{array}$ & $\begin{array}{c}\text { Target Organism } \\
\text { Concentration } \\
\text { (CFU/ml) }\end{array}$ & Salmonella & E. coli O157:H7 & L. monocytogenes \\
\hline & & & & \\
$0.50 \%$ & $5.0 \times 10^{1}$ & $24 \mathrm{~h}$ & $24 \mathrm{~h}$ & $24 \mathrm{~h}$ \\
$(\mathrm{pH} \mathrm{5.40)}$ & $5.0 \times 10^{2}$ & $24 \mathrm{~h}$ & $24 \mathrm{~h}$ & $24 \mathrm{~h}$ \\
& $5.0 \times 10^{4}$ & $24 \mathrm{~h}$ & $24 \mathrm{~h}$ & $24 \mathrm{~h}$ \\
$0.75 \%$ & $5.0 \times 10^{1}$ & $24 \mathrm{~h}$ & $24 \mathrm{~h}$ & $24 \mathrm{~h}$ \\
$(\mathrm{pH} \mathrm{5.38)}$ & $5.0 \times 10^{2}$ & $24 \mathrm{~h}$ & $24 \mathrm{~h}$ & $24 \mathrm{~h}$ \\
& $5.0 \times 10^{4}$ & $24 \mathrm{~h}$ & $24 \mathrm{~h}$ & $24 \mathrm{~h}$ \\
$1.0 \%$ & & & & \\
$(\mathrm{pH} \mathrm{5.27)}$ & $5.0 \times 10^{1}$ & $24 \mathrm{~h}$ & $24 \mathrm{~h}$ & $24 \mathrm{~h}$ \\
& $5.0 \times 10^{2}$ & $24 \mathrm{~h}$ & $24 \mathrm{~h}$ & $24 \mathrm{~h}$ \\
& $5.0 \times 10^{4}$ & $24 \mathrm{~h}$ & $24 \mathrm{~h}$ & $24 \mathrm{~h}$ \\
\hline
\end{tabular}

\subsubsection{Antimicrobial activity of sodium replacement agents in TSA}

There was no antimicrobial activity detected in any of the sodium replacement agents tested (Tables 3.11-3.16). Growth of Salmonella, E. coli O157:H7 and L. monocytogenes was detected after $24 \mathrm{~h}$ of incubation in all test conditions.

Table 3.11 Growth of Salmonella, E. coli 0157:H7 and L. monocytogenes on TSA (pH 5.8) supplemented with $\mathrm{KCl}$ and incubated at $35^{\circ} \mathrm{C}$.

\begin{tabular}{lcccc}
\hline $\begin{array}{l}\text { Antimicrobial } \\
\text { Concentration }\end{array}$ & $\begin{array}{c}\text { Target Organism } \\
\text { Concentration } \\
\text { (CFU/ml) }\end{array}$ & \multicolumn{3}{c}{ Time Until Observed Organism Growth } \\
& & & & \\
$1.0 \%$ & $5.0 \times 10^{1}$ & $24 \mathrm{~h}$ & $24 \mathrm{~h}$ & $24 \mathrm{~h}$ \\
& $5.0 \times 10^{2}$ & $24 \mathrm{~h}$ & $24 \mathrm{~h}$ & $24 \mathrm{~h}$ \\
& $5.0 \times 10^{4}$ & $24 \mathrm{~h}$ & $24 \mathrm{~h}$ & $24 \mathrm{~h}$ \\
$2.0 \%$ & $5.0 \times 10^{1}$ & $24 \mathrm{~h}$ & $24 \mathrm{~h}$ & $24 \mathrm{~h}$ \\
& $5.0 \times 10^{2}$ & $24 \mathrm{~h}$ & $24 \mathrm{~h}$ & $24 \mathrm{~h}$ \\
& $5.0 \times 10^{4}$ & $24 \mathrm{~h}$ & $24 \mathrm{~h}$ & $24 \mathrm{~h}$
\end{tabular}


Table 3.12 Growth of Salmonella, E. coli 0157:H7 and L. monocytogenes on TSA (pH 5.8) supplemented with Puracal PP/USP and incubated at $35^{\circ} \mathrm{C}$.

\begin{tabular}{lcccc}
\hline $\begin{array}{l}\text { Antimicrobial } \\
\text { Concentration }\end{array}$ & $\begin{array}{c}\text { Target Organism } \\
\text { Concentration } \\
\text { (CFU/ml) }\end{array}$ & $\begin{array}{c}\text { Time Until Observed Organism Growth } \\
\text { Salmonella }\end{array}$ & E. coli 0157:H7 & L. monocytogenes \\
\hline & & & & \\
$0.02 \%$ & $5.0 \times 10^{1}$ & $24 \mathrm{~h}$ & $24 \mathrm{~h}$ & $24 \mathrm{~h}$ \\
& $5.0 \times 10^{2}$ & $24 \mathrm{~h}$ & $24 \mathrm{~h}$ & $24 \mathrm{~h}$ \\
& $5.0 \times 10^{4}$ & $24 \mathrm{~h}$ & $24 \mathrm{~h}$ & $24 \mathrm{~h}$ \\
$0.04 \%$ & & & & \\
& $5.0 \times 101$ & $24 \mathrm{~h}$ & $24 \mathrm{~h}$ & $24 \mathrm{~h}$ \\
& $5.0 \times 10^{2}$ & $24 \mathrm{~h}$ & $24 \mathrm{~h}$ & $24 \mathrm{~h}$ \\
& $5.0 \times 10^{4}$ & $24 \mathrm{~h}$ & $24 \mathrm{~h}$ & $24 \mathrm{~h}$ \\
\hline
\end{tabular}

Table 3.13 Growth of Salmonella, E. coli 0157:H7 and L. monocytogenes on TSA (pH 5.8) supplemented with Purasal Hi Pure P Plus and incubated at $35^{\circ} \mathrm{C}$.

\begin{tabular}{lcccc}
\hline $\begin{array}{l}\text { Antimicrobial } \\
\text { Concentration }\end{array}$ & $\begin{array}{c}\text { Target Organism } \\
\text { Concentration } \\
\text { (CFU/ml) }\end{array}$ & \multicolumn{2}{c}{ Sime Until Observed Organism Growth } \\
& & & & \\
& $5.0 \times 10^{1}$ & $24 \mathrm{~h}$ & $24 \mathrm{~h}$ & $24 \mathrm{~h}$ \\
$0.02 \%$ & $5.0 \times 10^{2}$ & $24 \mathrm{~h}$ & $24 \mathrm{~h}$ & $24 \mathrm{~h}$ \\
& $5.0 \times 10^{4}$ & $24 \mathrm{~h}$ & $24 \mathrm{~h}$ & $24 \mathrm{~h}$ \\
& & & & \\
$0.04 \%$ & $5.0 \times 10^{1}$ & $24 \mathrm{~h}$ & $24 \mathrm{~h}$ & $24 \mathrm{~h}$ \\
& $5.0 \times 10^{2}$ & $24 \mathrm{~h}$ & $24 \mathrm{~h}$ & $24 \mathrm{~h}$ \\
& $5.0 \times 10^{4}$ & $24 \mathrm{~h}$ & $24 \mathrm{~h}$ & $24 \mathrm{~h}$
\end{tabular}

Table 3.14 Growth of Salmonella, E. coli 0157:H7 and L. monocytogenes on TSA (pH 5.8) supplemented with PuraQ Verdad NV10 and incubated at $35^{\circ} \mathrm{C}$.

\begin{tabular}{lcccc}
\hline $\begin{array}{l}\text { Antimicrobial } \\
\text { Concentration }\end{array}$ & $\begin{array}{c}\text { Target Organism } \\
\text { Concentration } \\
\text { (CFU/ml) }\end{array}$ & Salmonella & E. coli 0157:H7 & L. monocytogenes \\
\hline & & $24 \mathrm{~h}$ & $24 \mathrm{~h}$ & $24 \mathrm{~h}$ \\
$0.02 \%$ & $5.0 \times 10^{1}$ & $24 \mathrm{~h}$ & $24 \mathrm{~h}$ & $24 \mathrm{~h}$ \\
& $5.0 \times 10^{2}$ & $24 \mathrm{~h}$ & $24 \mathrm{~h}$ & $24 \mathrm{~h}$ \\
& $5.0 \times 10^{4}$ & & & \\
$0.04 \%$ & $5.0 \times 10^{1}$ & $24 \mathrm{~h}$ & $24 \mathrm{~h}$ & $24 \mathrm{~h}$ \\
& $5.0 \times 10^{2}$ & $24 \mathrm{~h}$ & $24 \mathrm{~h}$ & $24 \mathrm{~h}$ \\
& $5.0 \times 10^{4}$ & $24 \mathrm{~h}$ & $24 \mathrm{~h}$ & $24 \mathrm{~h}$ \\
\hline
\end{tabular}


Table 3.15 Growth of Salmonella, E. coli 0157:H7 and L. monocytogenes on TSA (pH 5.8) supplemented with SaltWise 0029 and incubated at $35^{\circ} \mathrm{C}$.

\begin{tabular}{|c|c|c|c|c|}
\hline \multirow{2}{*}{$\begin{array}{l}\text { Antimicrobial } \\
\text { Concentration }\end{array}$} & \multirow{2}{*}{$\begin{array}{c}\text { Target Organism } \\
\text { Concentration } \\
\text { (CFU/ml) }\end{array}$} & \multicolumn{3}{|c|}{ Time Until Observed Organism Growth } \\
\hline & & Salmonella & E. coli 0157:H7 & L. monocytogenes \\
\hline \multirow{3}{*}{$0.5 \%$} & $5.0 \times 10^{1}$ & $24 \mathrm{~h}$ & $24 \mathrm{~h}$ & $24 \mathrm{~h}$ \\
\hline & $5.0 \times 10^{2}$ & $24 \mathrm{~h}$ & $24 \mathrm{~h}$ & $24 \mathrm{~h}$ \\
\hline & $5.0 \times 10^{4}$ & $24 \mathrm{~h}$ & $24 \mathrm{~h}$ & $24 \mathrm{~h}$ \\
\hline \multirow{3}{*}{$1.0 \%$} & $5.0 \times 10^{1}$ & $24 \mathrm{~h}$ & $24 \mathrm{~h}$ & $24 \mathrm{~h}$ \\
\hline & $5.0 \times 10^{2}$ & $24 \mathrm{~h}$ & $24 \mathrm{~h}$ & $24 \mathrm{~h}$ \\
\hline & $5.0 \times 10^{4}$ & $24 \mathrm{~h}$ & $24 \mathrm{~h}$ & $24 \mathrm{~h}$ \\
\hline \multirow{3}{*}{$2.0 \%$} & $5.0 \times 10^{1}$ & $24 \mathrm{~h}$ & $24 \mathrm{~h}$ & $24 \mathrm{~h}$ \\
\hline & $5.0 \times 10^{2}$ & $24 \mathrm{~h}$ & $24 \mathrm{~h}$ & $24 \mathrm{~h}$ \\
\hline & $5.0 \times 10^{4}$ & $24 \mathrm{~h}$ & $24 \mathrm{~h}$ & $24 \mathrm{~h}$ \\
\hline
\end{tabular}

Table 3.16 Growth of Salmonella, E. coli 0157:H7 and L. monocytogenes on TSA supplemented with SaltWise 1029 and incubated at $35^{\circ} \mathrm{C}$.

\begin{tabular}{lcccc}
\hline $\begin{array}{l}\text { Antimicrobial } \\
\text { Concentration }\end{array}$ & $\begin{array}{c}\text { Target Organism } \\
\text { Concentration } \\
\text { (CFU/ml) }\end{array}$ & \multicolumn{3}{c}{ Time Until Observed Organism Growth } \\
& & & & \\
$0.5 \%$ & $5.0 \times 10^{1}$ & $24 \mathrm{~h}$ & $24 \mathrm{~h}$ & $24 \mathrm{~h}$ \\
& $5.0 \times 10^{2}$ & $24 \mathrm{~h}$ & $24 \mathrm{~h}$ & $24 \mathrm{~h}$ \\
& $5.0 \times 10^{4}$ & $24 \mathrm{~h}$ & $24 \mathrm{~h}$ & $24 \mathrm{~h}$ \\
$1.0 \%$ & $5.0 \times 10^{1}$ & $24 \mathrm{~h}$ & $24 \mathrm{~h}$ & $24 \mathrm{~h}$ \\
& $5.0 \times 10^{2}$ & $24 \mathrm{~h}$ & $24 \mathrm{~h}$ & $24 \mathrm{~h}$ \\
& $5.0 \times 10^{4}$ & $24 \mathrm{~h}$ & $24 \mathrm{~h}$ & $24 \mathrm{~h}$ \\
$2.0 \%$ & $5.0 \times 10^{1}$ & $24 \mathrm{~h}$ & $24 \mathrm{~h}$ & $24 \mathrm{~h}$ \\
& $5.0 \times 10^{2}$ & $24 \mathrm{~h}$ & $24 \mathrm{~h}$ & $24 \mathrm{~h}$ \\
& $5.0 \times 10^{4}$ & $24 \mathrm{~h}$ & $24 \mathrm{~h}$ & $24 \mathrm{~h}$
\end{tabular}




\subsection{Discussion}

Antimicrobials were screened for efficacy in order to reduce the number of antimicrobials used in the final cheese study. The eight antimicrobials screened consisted of four fermentates (MicroGard 100, MicroGard 430, PuraQ Verdad RV75 and VMY1P), a bacteriocin (Nisaplin), a lysozyme-containing blend (NovaGard CB1), lauric arginate (Protect-M) and a lactoperoxidase system (SEA-i F75). Fermentates are products of the in situ lactic acid bacteria (LAB) controlled acidification (Montville and Chikindas, 2007). This controlled acidification generates fermentation by products, such as organic acids, diacetyl and bacteriocin-like products, that are antimicrobial alone and in combination with each other. Fermentates used in this study included MicroGard 100, MicroGard 430, PuraQ Verdad RV75 and VMY1P.

One of the major antimicrobial components of fermentates is organic acids. Though the antimicrobial mechanism of organic acids is not fully understood, the possible bacterial targets include the cell wall, cytoplasmic membrane and metabolic functions within the cytoplasm (Ricke, 2003). It is believed that the undissociated forms of organic acids diffuse through the lipid membrane of the bacterial cell and, once inside the cytoplasm, dissociate into anions and protons. The increase in protons acidifies the cytoplasm and the bacterium must use energy, in the form of ATP, to pump excess protons out of the cell. The amount of time it takes to increase the $\mathrm{pH}$ to a point where growth may resume, or lag time, is dependent on the inhibitor concentration and the extracellular pH (Davidson and Taylor, 2007). Antimicrobial effectiveness of 
organic acids is related to $\mathrm{pH}$ and the acid dissociation constant, or $\mathrm{pK}_{\mathrm{a}}$. Generally, the undissociated form of the acid is responsible for the antimicrobial effectiveness of organic acids; organic acids are more effective when the majority of the acid is in the undissociated form or when the $\mathrm{pH}<\mathrm{pK}_{\mathrm{a}}$.

MicroGard 100 and MicroGard 430 provided little to no inhibition of the organisms tested in TSA. MicroGard products are produced through the fermentation of grade A skim milk by Propionibacterium shermanii. Antimicrobial activity of MicroGard products is derived from the bacteriocin-like products, including diacetyl as well as lactic, acetic and propionic acids, produced during fermentation (Stasweski and Jagus, 2008). Lactic, acetic and propionic acids have $\mathrm{pK}_{\mathrm{a}}$ values of $3.79,4.75$ and 4.87 , respectively. The $\mathrm{pH}$ of TSA in this study, after adjustment and the addition of Microgard products, was 5.02 or greater. Since the $\mathrm{pH}$ is greater than each of the respective $\mathrm{pK}_{\mathrm{a}}$ values the majority of the acid would be in the dissociated form and the antimicrobial efficacy of the organic acid would be reduced.

In addition to the organic acids, MicroGard products contain diacetyl which has been shown to possess broad antimicrobial activity when utilized at concentrations ranging between 200 and 1000 ppm (Lanciotti et al., 2003). Diacetyl inhibited the growth of E. coli, Salmonella, S. aureus, and L.monocytogenes, with Gram-positive organisms showing more resistance (Kang and Fung, 1999; Lanciotti et al., 2003). In this study, diacetyl, despite being combined with other components of MicroGard products, proved to be ineffective at inhibiting the organisms tested in TSA, an ideal medium for bacterial growth. 
Though the concentration of diacetyl in the MicroGard products was not determined in this study, diacetyl, at a concentration of $344 \mathrm{ppm}$, previously lacked effectiveness against Gram-negative and Gram-positive organisms in BHI broth, another ideal medium (Jay, 1982). Preliminary studies showed the lack of effectiveness in $\mathrm{BHI}$ was most likely due to the nutrient composition of the medium and the relatively high incubation temperature; diacetyl is more effective at $10^{\circ}$ and $20^{\circ} \mathrm{C}$ than at $37^{\circ} \mathrm{C}$. The combination of the elevated temperature, higher $\mathrm{pH}$ and the nutrient-rich medium created an environment that was extremely ideal for the growth of microorganisms, reducing the efficacy of the MicroGard products.

The other two fermentates tested were PuraQ Verdad RV75 and VMY1P. PuraQ Verdad RV75 provided partial inhibition while VMY1P could not inhibit the growth of the three organisms tested in TSA. Exact components and active ingredients of PuraQ Verdad RV75 and VMY1P are not known. However, as products are typically cultured by Lactobacillus species, it is likely they contain mainly lactic acid and trace amounts of acetate or propionate. As previously stated, antimicrobial activity of organic acids relies heavily on the $\mathrm{pH}$ of the environment. TSA was adjusted to a $\mathrm{pH}$ of 5.8 prior to the addition of the antimicrobials to simulate the $\mathrm{pH}$ of mozzarella cheese. After the addition of the fermentates, the lowest $\mathrm{pH}$ values observed for PuraQ Verdad RV75 and VMY1P were 5.60 and 5.27 , respectively. These $\mathrm{pH}$ values are much higher than the $\mathrm{pK}_{\mathrm{a}}$ of the organic acids. The concentrations of PuraQ Verdad RV75 and 
VMY1P used in this study were not able to provide antimicrobial activity at such a high $\mathrm{pH}$ value and under such favorable conditions for microbial growth.

Nisaplin, at the concentrations used in this study, was unable to prevent the growth of $L$. monocytogenes in TSA. The active component in Nisaplin is nisin, a bacteriocin produced by Lactococcus lactis. Bacteriocins attach to the cell wall and act by creating pores in the cellular membrane, which causes cytoplasmic leakage, eventually leading to cell lysis (Dave et al., 2003). The antimicrobial activity of nisin is dependent upon the incubation temperature and $\mathrm{pH}$ of the product; in general, nisin is most effective against Gram-positive organisms and at lower incubation temperatures and in acidic environments (Montville and Chikindas, 2007). After pH adjustment and the addition of Nisaplin, the pH of TSA remained close to 5.8 at every concentration tested. Growth of $L$. monoytogenes was permitted in tryptic soy broth (TSB) after supplementation with Nisaplin at pH values of less than 5.60 (Boziaris and Nychas, 2006). The efficacy of nisin is highly dependent upon the presence of other microbial hurdles, such as low $\mathrm{pH}$ and low incubation temperatures. The absence of other microbial hurdles, low incubation temperature or acidic environment, Nisaplin was ineffective at preventive microbial growth.

NovaGard CB1 delayed the growth of test pathogens when used at a concentration of $2.0 \%$ in TSA. NovaGard CB1 is a blend of lysozyme, nisin and other organic acids which allows it to attack several different cells target areas simultaneously. Lysozyme, the primary antimicrobial compound in egg albumen, works by attacking the peptidoglycan of the cell wall, causing 
degradation and lysis (Davidson and Taylor, 2007). Lysozyme is typically more effective at lower temperatures where cell growth is slowed (Hughey and Johnson, 1987). The elevated incubation temperature used in this study promoted the rapid growth of the microorganisms tested; it is likely that the cell wall synthesis in the rapidly growing cultures exceeded the rate of cell wall degradation by the lysozyme. Lysozyme is also most active against Grampositive bacteria because of the accessibility to the peptidoglycan of the cell wall. However, in this study, a delay in the growth of Gram-negative organisms was also observed. Other active components in NovaGard CB1 potentially contributed to this delay in growth.

Protect-M, a commercial source of lauric arginate (LAE), was highly effective at inhibiting all three organisms in TSA. In Gram-negative cells, LAE works by altering the cytoplasmic membrane and the external membrane while in Gram-positive cells, the surfactant works by altering the cell membrane and cytoplasm (Rodriguez et al., 2004). Though the cells do not lyse, these alterations disrupt the membrane causing ion leakage and a loss of cell viability. Efficacy of LAE is determined by the food matrix; as a cationic surfactant, it may interact with anionic components of the food matrix through electrostatic interactions resulting in either an enhancement or reduction of its activity (Asker et al., 2009). Protect-M provided inhibition against Gram-negative and Grampositive cells in TSA; it stands to reason that the lauric arginate interacted with anionic components in the agar, most likely chloride, which resulted in an enhancement of its antimicrobial activity. 
SEA-i F75, a lactoperoxidase-based system, inhibited the growth of the three organisms tested. Mechanisms of antimicrobial activity of the lactoperoxidase system include the deactivation of cellular enzymes, interference with membrane proteins and the inhibition of the transport of amino acids and sugars. The activity of lactoperoxidase is dependent upon the presence of hydrogen peroxide $\left(\mathrm{H}_{2} \mathrm{O}_{2}\right)$ and either thiocyanate or a halide. Because lactoperoxidase needs $\mathrm{H}_{2} \mathrm{O}_{2}$, SEA-i F75 contains glucose oxidase, which utilizes glucose and oxygen to produce $\mathrm{H}_{2} \mathrm{O}_{2}$. Lactoperoxidase is highly inihibitory to Gram-negative pathogens and has exhibited antimicrobial activity against Grampositive organisms as well (Arques et al., 2008a; Arques et al., 2008b; Davidson and Taylor, 2007).

Our results showed that SEA-i F75 was highly effective at inhibiting the growth of Gram-negative and Gram-positive organisms. Since thiocyanate was not added to the agar, we presume that TSA supported the action of the lactoperoxidase in SEA-i F75 by contributing chloride, the necessary halide, in addition to the $\mathrm{H}_{2} \mathrm{O}_{2}$ produced by the glucose oxidase, for antimicrobial activity.

The six sodium replacement agents tested consisted of two lactates, a fermentate and three containing $\mathrm{KCl}$. Sodium replacement agents were tested for antimicrobial activity to determine if they could be used solely (without the addition of an antimicrobial) or if they could potentially increase the efficacy of an antimicrobial in the food matrix. No antimicrobial activity was observed when sodium replacement agents were tested in TSA. Though the main function of these products is to enhance the flavor of low sodium products, $\mathrm{KCl}$ has also 
been shown to have some antimicrobial activity. Equal molar concentrations of $\mathrm{NaCl}$ and $\mathrm{KCl}$ have shown similar antimicrobial effects, in terms of lag time, growth or death rate, against $L$. monocytogenes (Boziaris et al., 2007). $\mathrm{KCl}$ is able to inhibit the growth of microorganisms through a reduction in water activity, similar to $\mathrm{NaCl}$. However, water activity between agars supplemented with each of the sodium replacement agents did not vary significantly and $\mathrm{KCl}$ did not display any inhibitory activity in this study (data not show). The TSA matrix is highly favorable for the growth of microorganisms; sodium replacement agents, at the concentrations tested, did not provide any inhibition of the microorganisms in TSA.

\subsection{Conclusion}

Four antimicrobials, NovaGard CB1, Protect-M, PuraQ Verdad RV75 and SEA-i F75 showed the most inhibition of E. coli O157:H7, Salmonella and L. monocytogenes growth in TSA. The composition of the food matrix can affect the growth of the microorganisms as well as the efficacy of antimicrobials. Because of this, all antimicrobials were challenged in milk agar to determine if the change in the matrix composition would affect the antimicrobial efficacy. 


\subsection{Antimicrobial Efficacy Screening in Milk Agar}

\subsection{Objectives}

To determine the antimicrobial efficacy of commercially available antimicrobials and sodium replacement agents in milk agar.

\subsection{Hypothesis}

Efficacy of antimicrobials and sodium replacement agents will be increased in milk agar.

\subsection{Materials and Methods}

\subsubsection{Bacterial Strains}

Five strains of each E. coli O157:H7, Listeria monocytogenes and Salmonella were used in the study. E. coli O157:H7 strains NFPA 4212, NFPA 4213, NFPA 4216, NFPA 4217, and NFPA 4219 were obtained from the culture collection of the National Food Laboratory (Livermore, CA). Two of the Listeria monocytogenes strains, NFPA 6301 and NFPA 6306, were obtained from the culture collection of the National Food Laboratory (Livermore, CA) while the other three strains, NRRL B-33000, NRRL B-33096, and NRRL B-33113 were received from the National Center for Agricultural Utilization Research (Peoria, IL). Salmonella enterica strains, Salmonella Javiana FSL S5-406, Salmonella Enteriditis FSL S5-415, Salmonella Heidelburg FSL S5-448, Salmonella 
Oranienburg FSL S5-642, and Salmonella Typhimurium FSL W1-030, were obtained from the International Life Sciences Institute, North America (Cornell University, Ithaca, NY).

All strains were stored in cryogenic vials (Fisher Scientific, Hanover Park, IL) at $-70^{\circ} \mathrm{C}$ for long-term preservation. Prior to use, cultures were streaked on selective media and incubated at $35^{\circ} \mathrm{C}$ for $24 \mathrm{~h}$. Salmonella strains were streaked on Xylose Lysine Deoxycholate Agar (XLD, Neogen, Lansing, MI), while Modified Oxford Agar (MOX, Difco, Sparks, MD) was used for Listeria monocytogenes and MacConkey Agar with Sorbitol (SMAC, Neogen, Lansing, MI) was used for E. coli O157:H7. Isolated colonies were used for inoculum preparation.

\subsubsection{Preparation of Inocula}

Each strain was individually transferred into $10 \mathrm{ml}$ of Tryptic Soy Broth (TSB, Neogen, Lansing, Ml) and grown at $35^{\circ} \mathrm{C}$ for $18 \mathrm{~h}$. After incubation, equal volumes of each strain were pooled within a species to form a cocktail. Each cocktail was centrifuged (1,800 $\mathrm{g} \times 15 \mathrm{~min})$, washed twice with $0.1 \%$ peptone water and resuspended in $0.1 \%$ peptone water. Direct microscope count (DMC) was done with a Petroff-Hausser Counting Chamber (Hausser Scientific, Horsham, PA) to determine the initial stock concentration. Cocktails were diluted to the target concentration using $0.1 \%$ peptone water. Initial counts were confirmed by plating on Tryptic Soy Agar (TSA, Neogen, Lansing, MI) and incubating at $35^{\circ} \mathrm{C}$ for $24 \mathrm{~h}$. 


\subsubsection{Antimicrobials and Sodium Replacement Agents}

Eight antimicrobials received from several suppliers were used in the study (Table 4.1). They consisted of MicroGard 100, MicroGard 430, Nisaplin, NovaGard CB1, Protect-M, PuraQ Verdad RV 75, SEA-i F75 and VMY1P. Six sodium replacement agents received from several suppliers were also used in the study (Table 4.2). These included potassium chloride, Puracal PP/USP, PuraQ Verdad NV10, Purasal Hi Pure P Plus, SaltWise 0029 and SaltWise 1029. Antimicrobials and sodium replacement agents were stored per manufacturer's recommendation until used in the study.

\subsubsection{Antimicrobial Efficacy Determination}

The efficacy of the antimicrobials was determined using an agar dilution method (Oussalah et al., 2007b). Milk agar was prepared by dissolving nonfat dry milk (8 $\mathrm{g} / \mathrm{L})$ and agar $(15 \mathrm{~g} / \mathrm{L})$ in deionized water. Agar was autoclaved at $121^{\circ} \mathrm{C}$ for 15 minutes then tempered prior to use. Antimicrobials and sodium replacement agents were added to tempered milk agar at various concentrations (Tables 4.1 and 4.2). Concentrations used for each antimicrobial and sodium replacement agent were determined using manufacturer recommendations and preliminary results in tryptic soy agar (TSA). The supplemented agars were poured into sterile petri plates and allowed to solidify. Salmonella, $L$.

monocytogenes or E. coli $\mathrm{O} 157: \mathrm{H} 7$ was spread plated onto solidified milk agar at a target concentration of $10^{1}, 10^{2}$ and $10^{4} \mathrm{CFU} / \mathrm{ml}$. Uninoculated milk agar plates served as negative controls while inoculated plates, without antimicrobial added, 
served as positive controls. Uninoculated supplemented agar plates were also tested for $\mathrm{pH}$. All test and control plates were incubated at $35^{\circ} \mathrm{C}$ for $48 \mathrm{~h}$. Plates were observed after $24 \mathrm{~h}$ and $48 \mathrm{~h}$ for presence or absence of growth. For all plates, absence of growth indicated the antimicrobial had an inhibitory effect.

Table 4.1 Description and concentrations of antimicrobials used to determine antimicrobial efficacy in milk agar screening.

\begin{tabular}{|c|c|c|c|c|}
\hline Antimicrobial & Manufacturer & Product Description & \multicolumn{2}{|c|}{$\begin{array}{c}\text { Concentrations Used } \\
(\%)\end{array}$} \\
\hline MicroGard 100 & Danisco & $\begin{array}{l}\text { Cultured Grade A Nonfat Dry Milk Powder; } \\
\text { Propionic Acid; Acetate }\end{array}$ & 0.5 & 1.0 \\
\hline MicroGard 430 & Danisco & $\begin{array}{l}\text { Cultured Grade A Nonfat Dry Milk Powder; } \\
\text { Maltodextrin; Propionic Acid; Acetate }\end{array}$ & 0.5 & 1.0 \\
\hline Nisaplin & Danisco & Nisin; $\mathrm{NaCl}$ & 0.03 & 0.10 \\
\hline $\begin{array}{l}\text { NovaGard } \\
\text { CB1 }\end{array}$ & Danisco & $\begin{array}{l}\text { Maltodextrin; Cultured Dextrose; Sodium } \\
\text { Diacetate; NaCl; Lysozyme; Nisin }\end{array}$ & 1.0 & 2.0 \\
\hline Protect-M & Purac & Lauric Arginate & 0.10 & 0.20 \\
\hline $\begin{array}{l}\text { PuraQ Verdad } \\
\text { RV75 }\end{array}$ & Purac & $\begin{array}{c}\text { Cultured Sugar; Organic Acids; Residual } \\
\text { Sugars }\end{array}$ & 0.2 & 0.4 \\
\hline SEA-i F75 & Bienca & $\begin{array}{l}\text { Glucose; Glucose Oxidase; Whey; } \\
\text { Lactoperoxidase; Lactose; Casein }\end{array}$ & 0.25 & 0.50 \\
\hline VMY1P & Purac & Cultured Whey & 0.5 & 1.0 \\
\hline
\end{tabular}


Table 4.2 Description and concentrations of sodium replacement agents used to determine antimicrobial efficacy in milk agar.

\begin{tabular}{|c|c|c|c|c|}
\hline $\begin{array}{l}\text { Sodium Replacement } \\
\text { Agents }\end{array}$ & Manufacturer & Product Description & \multicolumn{2}{|c|}{$\begin{array}{c}\text { Concentrations Used } \\
(\%)\end{array}$} \\
\hline Potassium Chloride & Cargill & Potassium chloride & 1.0 & 2.0 \\
\hline Puracal PP/USP & Purac & Calcium lactate & 0.02 & 0.04 \\
\hline $\begin{array}{l}\text { Puracal Hi Pure P } \\
\text { Plus }\end{array}$ & Purac & Potassium lactate & 0.02 & 0.04 \\
\hline PuraQ Verdad NV10 & Purac & Cultured corn sugar & 0.02 & 0.04 \\
\hline SaltWise 0029 & Cargill & $\begin{array}{c}\text { Potassium chloride; trehalose; } \\
\text { autolyzed yeast extract; silicon } \\
\text { dioxide }\end{array}$ & 1.0 & 2.0 \\
\hline SaltWise 1029 & Cargill & $\begin{array}{l}\text { Potassium chloride; trehalose; } \\
\text { autolyzed yeast extract; silicon } \\
\text { dioxide }\end{array}$ & 1.0 & 2.0 \\
\hline
\end{tabular}

\subsection{Results}

\subsubsection{Efficacy of Antimicrobials against Salmonella, E. coli O157:H7 and L. monocytogenes in Milk Agar}

At a MicroGard 100 concentration of $0.5 \%$, Salmonella and E. coli O157:H7 grew on supplemented milk agar at all inoculum levels after $24 \mathrm{~h}$ (Table 4.3). Increasing the concentration of MicroGard 100 to $1.0 \%$ delayed the growth of E. coli O157:H7 at the lowest inoculum concentration and Salmonella at all concentrations. At a MicroGard 430 concentration of $0.5 \%$, L. monocytogenes, Salmonella and E. coli $\mathrm{O} 157: \mathrm{H} 7$ grew on the supplemented milk agar at all 
inoculum levels after $24 \mathrm{~h}$ (Table 4.4). An increase in concentration to $1.0 \%$ did not affect L. monocytogenes; however, the growth of E. coli O157:H7 at the lowest inoculum level and Salmonella at all inoculum levels was delayed. Growth of L. monocytogenes was observed in milk agar supplemented with Nisaplin, at the highest and lowest inoculum level after $24 \mathrm{~h}$ and $48 \mathrm{~h}$, respectively (Table 4.5). NovaGard CB1 completely inhibited the growth of Salmonella, E. coli O157:H7 and L. monocytogenes in milk agar at all antimicrobial concentrations and inoculum levels tested (Table 4.6). Protect-M was highly effective at inhibiting the growth of $L$. monocytogenes and $E$. coli O157:H7 in milk agar (Table 4.7). All test conditions yielded no growth of either organism after $48 \mathrm{~h}$. However, growth of Salmonella was observed at all inoculum levels with an antimicrobial concentration of $0.1 \%$ after $48 \mathrm{~h}$. A concentration of $0.2 \%$ was needed to inhibit the growth of Salmonella. PuraQ Verdad RV75 and SEA-i F75 completely inhibited the growth of Salmonella, E. coli $\mathrm{O} 157: \mathrm{H} 7$ and L. monocytogenes in milk agar at all antimicrobial concentrations and inoculum levels tested (Tables 4.8 and 4.9). Growth of Salmonella, E. coli O157:H7 and L. monocytogenes on milk agar supplemented with VMY1P at a concentration of $0.5 \%$ was detected after $48 \mathrm{~h}$ of incubation. Increasing the concentration to $1.0 \%$ inhibited the growth of all organisms tested at all inoculum levels. 
Table 4.3 Growth of Salmonella and E. coli 0157:H7 on milk agar supplemented with MicroGard 100 and incubated at $35^{\circ} \mathrm{C}$.

\begin{tabular}{cccc}
\hline $\begin{array}{c}\text { Antimicrobial } \\
\text { Concentration }\end{array}$ & $\begin{array}{c}\text { Target Organism } \\
\text { Concentration (CFU/ml) }\end{array}$ & \multicolumn{2}{c}{ Time Until Observed Organism Growth } \\
Salmonella & E. coli 0157:H7 \\
\hline $0.5 \%$ & $5.0 \times 10^{1}$ & $24 \mathrm{~h}$ & $24 \mathrm{~h}$ \\
$(\mathrm{pH} \mathrm{6.72)}$ & $5.0 \times 10^{2}$ & $24 \mathrm{~h}$ & $24 \mathrm{~h}$ \\
& $5.0 \times 10^{4}$ & $24 \mathrm{~h}$ & $24 \mathrm{~h}$ \\
$1.0 \%$ & $5.0 \times 10^{1}$ & $48 \mathrm{~h}$ & $48 \mathrm{~h}$ \\
$(\mathrm{pH} \mathrm{6.71)}$ & $5.0 \times 10^{2}$ & $48 \mathrm{~h}$ & $24 \mathrm{~h}$ \\
& $5.0 \times 10^{4}$ & $48 \mathrm{~h}$ & $24 \mathrm{~h}$ \\
\hline
\end{tabular}

Table 4.4 Growth of Salmonella, E. coli 0157:H7 and L. monocytogenes on milk agar supplemented with MicroGard 430 and incubated at $35^{\circ} \mathrm{C}$.

\begin{tabular}{ccccc}
\hline $\begin{array}{c}\text { Antimicrobial } \\
\text { Concentration }\end{array}$ & $\begin{array}{c}\text { Target Organism } \\
\text { Concentration } \\
\text { (CFU/ml) }\end{array}$ & Salmonella & E. coli O157:H7 & L. monocytogenes \\
\hline & & & & \\
$0.50 \%$ & $5.0 \times 10^{1}$ & $24 \mathrm{~h}$ & $24 \mathrm{~h}$ & $24 \mathrm{~h}$ \\
$(\mathrm{pH} \mathrm{5.93)}$ & $5.0 \times 10^{2}$ & $24 \mathrm{~h}$ & $24 \mathrm{~h}$ & $24 \mathrm{~h}$ \\
& $5.0 \times 10^{4}$ & $24 \mathrm{~h}$ & $24 \mathrm{~h}$ & $24 \mathrm{~h}$ \\
$1.0 \%$ & $5.0 \times 10^{1}$ & $48 \mathrm{~h}$ & $48 \mathrm{~h}$ & $24 \mathrm{~h}$ \\
$(\mathrm{pH} \mathrm{5.61)}$ & $5.0 \times 10^{2}$ & $48 \mathrm{~h}$ & $24 \mathrm{~h}$ & $24 \mathrm{~h}$ \\
& $5.0 \times 10^{4}$ & $48 \mathrm{~h}$ & $24 \mathrm{~h}$ & $24 \mathrm{~h}$ \\
\hline
\end{tabular}

Table 4.5 Growth of Listeria monocytogenes on milk agar supplemented with Nisaplin and incubated at $35^{\circ} \mathrm{C}$.

\begin{tabular}{ccc}
\hline $\begin{array}{c}\text { Antimicrobial } \\
\text { Concentration }\end{array}$ & $\begin{array}{c}\text { Target Organism Concentration } \\
\text { (CFU/ml) }\end{array}$ & Time Until Observed Organism Growth \\
\hline $0.03 \%$ & $5.0 \times 10^{1}$ & $48 \mathrm{~h}$ \\
$(\mathrm{pH} 6.74)$ & $5.0 \times 10^{2}$ & $48 \mathrm{~h}$ \\
& $5.0 \times 10^{4}$ & $24 \mathrm{~h}$ \\
$0.10 \%$ & $5.0 \times 10^{1}$ & $48 \mathrm{~h}$ \\
$(\mathrm{pH} 6.66)$ & $5.0 \times 10^{2}$ & $48 \mathrm{~h}$ \\
& $5.0 \times 10^{4}$ & $24 \mathrm{~h}$ \\
\hline
\end{tabular}


Table 4.6 Growth of Salmonella, E. coli 0157:H7 and L. monocytogenes on milk agar supplemented with NovaGard $\mathrm{CB} 1$ and incubated at $35^{\circ} \mathrm{C}$.

\begin{tabular}{ccccc}
\hline $\begin{array}{c}\text { Antimicrobial } \\
\text { Concentration }\end{array}$ & $\begin{array}{c}\text { Target Organism } \\
\text { Concentration } \\
\text { (CFU/ml) }\end{array}$ & \multicolumn{3}{c}{ Time Until Observed Organism Growth } \\
& Salmonella & E. coli O157:H7 & L. monocytogenes \\
\hline $1.0 \%$ & $5.0 \times 10^{1}$ & $\mathrm{NG} 1$ & $\mathrm{NG}$ & $\mathrm{NG}$ \\
$(\mathrm{pH} \mathrm{5.49)}$ & $5.0 \times 10^{2}$ & $\mathrm{NG}$ & $\mathrm{NG}$ & $\mathrm{NG}$ \\
& $5.0 \times 10^{4}$ & $\mathrm{NG}$ & $\mathrm{NG}$ & $\mathrm{NG}$ \\
$2.0 \%$ & $5.0 \times 10^{1}$ & $\mathrm{NG}$ & $\mathrm{NG}$ & $\mathrm{NG}$ \\
$(\mathrm{pH} \mathrm{5.27)}$ & $5.0 \times 10^{2}$ & $\mathrm{NG}$ & $\mathrm{NG}$ & $\mathrm{NG}$ \\
& $5.0 \times 10^{4}$ & $\mathrm{NG}$ & $\mathrm{NG}$ & $\mathrm{NG}$ \\
\hline
\end{tabular}

${ }^{1} \mathrm{NG}$ : No growth detected after 48 hours of incubation at $35^{\circ} \mathrm{C}$.

Table 4.7 Growth of Salmonella, E. coli 0157:H7 and L. monocytogenes on milk agar supplemented with Protect-M and incubated at $35^{\circ} \mathrm{C}$.

\begin{tabular}{ccccc}
\hline $\begin{array}{c}\text { Antimicrobial } \\
\text { Concentration }\end{array}$ & $\begin{array}{c}\text { Target Organism } \\
\text { Concentration } \\
\text { (CFU/ml) }\end{array}$ & \multicolumn{3}{c}{ Time Until Observed Organism Growth } \\
& Salmonella & E. coli O157:H7 & L. monocytogenes \\
$0.10 \%$ & $5.0 \times 10^{1}$ & $48 \mathrm{~h}$ & $\mathrm{NG}$ & $\mathrm{NG}$ \\
$(\mathrm{pH} 6.41)$ & $5.0 \times 10^{2}$ & $48 \mathrm{~h}$ & $\mathrm{NG}$ & $\mathrm{NG}$ \\
& $5.0 \times 10^{4}$ & $48 \mathrm{~h}$ & $\mathrm{NG}$ & $\mathrm{NG}$ \\
$0.20 \%$ & $5.0 \times 10^{1}$ & $\mathrm{NG} 1$ & $\mathrm{NG}$ & $\mathrm{NG}$ \\
$(6.42)$ & $5.0 \times 10^{2}$ & $\mathrm{NG}$ & $\mathrm{NG}$ & $\mathrm{NG}$ \\
& $5.0 \times 10^{4}$ & $\mathrm{NG}$ & $\mathrm{NG}$ & $\mathrm{NG}$
\end{tabular}

${ }^{1} \mathrm{NG}$ : No growth detected after 48 hours of incubation at $35^{\circ} \mathrm{C}$.

Table 4.8 Growth of Salmonella, E. coli 0157:H7 and L. monocytogenes on milk agar supplemented with PuraQ Verdad RV75 and incubated at $35^{\circ} \mathrm{C}$.

\begin{tabular}{ccccc}
\hline $\begin{array}{c}\text { Antimicrobial } \\
\text { Concentration }\end{array}$ & $\begin{array}{c}\text { Target Organism } \\
\text { Concentration } \\
\text { (CFU/ml) }\end{array}$ & $\begin{array}{c}\text { Time Until Observed Organism Growth } \\
\text { Salmonella }\end{array}$ & E. coli O157:H7 & L. monocytogenes \\
\hline $0.2 \%$ & $5.0 \times 10^{1}$ & NG & NG & NG \\
$(\mathrm{pH} 4.78)$ & $5.0 \times 10^{2}$ & NG & NG & NG \\
& $5.0 \times 10^{4}$ & NG & NG & NG \\
$0.4 \%$ & $5.0 \times 10^{1}$ & NG & NG & NG \\
$(\mathrm{pH} 4.70)$ & $5.0 \times 10^{2}$ & NG & NG & NG \\
& $5.0 \times 10^{4}$ & NG & NG & NG
\end{tabular}


Table 4.9 Growth of Salmonella, E. coli 0157:H7 and L. monocytogenes on milk agar supplemented with SEA-i F75 and incubated at $35^{\circ} \mathrm{C}$.

\begin{tabular}{ccccc}
\hline $\begin{array}{c}\text { Antimicrobial } \\
\text { Concentration }\end{array}$ & $\begin{array}{c}\text { Target Organism } \\
\text { Concentration } \\
\text { (CFU/ml) }\end{array}$ & $\begin{array}{c}\text { Time Until Observed Organism Growth } \\
\text { Salmonella }\end{array}$ & E. coli 0157:H7 & L. monocytogenes \\
\hline $0.25 \%$ & $5.0 \times 10^{1}$ & NG 1 & NG & NG \\
$(\mathrm{pH} \mathrm{5.39)}$ & $5.0 \times 10^{2}$ & $\mathrm{NG}$ & $\mathrm{NG}$ & $\mathrm{NG}$ \\
& $5.0 \times 10^{4}$ & $\mathrm{NG}$ & $\mathrm{NG}$ & $\mathrm{NG}$ \\
$0.50 \%$ & $5.0 \times 10^{1}$ & $\mathrm{NG}$ & $\mathrm{NG}$ & $\mathrm{NG}$ \\
$(\mathrm{pH} 4.97)$ & $5.0 \times 10^{2}$ & $\mathrm{NG}$ & $\mathrm{NG}$ & $\mathrm{NG}$ \\
& $5.0 \times 10^{4}$ & $\mathrm{NG}$ & $\mathrm{NG}$ & $\mathrm{NG}$ \\
\hline
\end{tabular}

${ }^{1} \mathrm{NG}$ : No growth detected after 48 hours of incubation at $35^{\circ} \mathrm{C}$.

Table 4.10 Growth of Salmonella, E. coli 0157:H7 and L. monocytogenes on milk agar supplemented with VMY1P and incubated at $35^{\circ} \mathrm{C}$.

\begin{tabular}{ccccc}
\hline $\begin{array}{c}\text { Antimicrobial } \\
\text { Concentration }\end{array}$ & $\begin{array}{c}\text { Target Organism } \\
\text { Concentration } \\
\text { (CFU/ml) }\end{array}$ & Salmonella & E. coli 0157:H7 & L. monocytogenes \\
\hline & $5.0 \times 10^{1}$ & $24 \mathrm{~h}$ & $48 \mathrm{~h}$ & $48 \mathrm{~h}$ \\
$0.50 \%$ & $5.0 \times 10^{2}$ & $24 \mathrm{~h}$ & $24 \mathrm{~h}$ & $48 \mathrm{~h}$ \\
$(\mathrm{pH} \mathrm{5.67)}$ & $5.0 \times 10^{4}$ & $24 \mathrm{~h}$ & $24 \mathrm{~h}$ & $24 \mathrm{~h}$ \\
& & & & \\
$1.0 \%$ & $5.0 \times 10^{1}$ & NG 1 & NG & NG \\
$(\mathrm{pH} \mathrm{5.38)}$ & $5.0 \times 10^{2}$ & NG & NG & NG \\
& $5.0 \times 10^{4}$ & NG & NG & NG
\end{tabular}

${ }^{1} \mathrm{NG}$ : No growth detected after 48 hours of incubation at $35^{\circ} \mathrm{C}$.

\subsubsection{Antimicrobial Activity of Sodium Replacement Agents in Milk Agar}

There was no antimicrobial activity detected in any of the sodium replacement agents tested (Tables 4.11-4.16). Growth of Salmonella, E. coli O157:H7 and L. monocytogenes was detected after $24 \mathrm{~h}$ of incubation in all test conditions. 
Table 4.11 Growth of Salmonella, E. coli 0157:H7 and L. monocytogenes on milk agar supplemented with $\mathrm{KCl}$ and incubated at $35^{\circ} \mathrm{C}$.

\begin{tabular}{lcccc}
\hline $\begin{array}{l}\text { Antimicrobial } \\
\text { Concentration }\end{array}$ & $\begin{array}{c}\text { Target Organism } \\
\text { Concentration } \\
\text { (CFU/ml) }\end{array}$ & $\begin{array}{c}\text { Time Until Observed Organism Growth } \\
\text { Salmonella }\end{array}$ & E. coli 0157:H7 & L. monocytogenes \\
\hline & & & & \\
$1.0 \%$ & $5.0 \times 10^{1}$ & $24 \mathrm{~h}$ & $24 \mathrm{~h}$ & $24 \mathrm{~h}$ \\
& $5.0 \times 10^{2}$ & $24 \mathrm{~h}$ & $24 \mathrm{~h}$ & $24 \mathrm{~h}$ \\
& $5.0 \times 10^{4}$ & $24 \mathrm{~h}$ & $24 \mathrm{~h}$ & $24 \mathrm{~h}$ \\
$2.0 \%$ & & & & \\
& $5.0 \times 101$ & $24 \mathrm{~h}$ & $24 \mathrm{~h}$ & $24 \mathrm{~h}$ \\
& $5.0 \times 10^{2}$ & $24 \mathrm{~h}$ & $24 \mathrm{~h}$ & $24 \mathrm{~h}$ \\
& $5.0 \times 10^{4}$ & $24 \mathrm{~h}$ & $24 \mathrm{~h}$ & $24 \mathrm{~h}$ \\
\hline
\end{tabular}

Table 4.12 Growth of Salmonella, E. coli 0157:H7 and L. monocytogenes on milk agar supplemented with Puracal PP/USP and incubated at $35^{\circ} \mathrm{C}$.

\begin{tabular}{lcccc}
\hline $\begin{array}{l}\text { Antimicrobial } \\
\text { Concentration }\end{array}$ & $\begin{array}{c}\text { Target Organism } \\
\text { Concentration } \\
\text { (CFU/ml) }\end{array}$ & \multicolumn{2}{c}{ Time Until Observed Organism Growth } \\
& & & & \\
& $5.0 \times 10^{1}$ & $24 \mathrm{~h}$ & $24 \mathrm{~h}$ & $24 \mathrm{~h}$ \\
$0.02 \%$ & $5.0 \times 10^{2}$ & $24 \mathrm{~h}$ & $24 \mathrm{~h}$ & $24 \mathrm{~h}$ \\
& $5.0 \times 10^{4}$ & $24 \mathrm{~h}$ & $24 \mathrm{~h}$ & $24 \mathrm{~h}$ \\
& & & & \\
$0.04 \%$ & $5.0 \times 10^{1}$ & $24 \mathrm{~h}$ & $24 \mathrm{~h}$ & $24 \mathrm{~h}$ \\
& $5.0 \times 10^{2}$ & $24 \mathrm{~h}$ & $24 \mathrm{~h}$ & $24 \mathrm{~h}$ \\
& $5.0 \times 10^{4}$ & $24 \mathrm{~h}$ & $24 \mathrm{~h}$ & $24 \mathrm{~h}$
\end{tabular}

Table 4.13 Growth of Salmonella, E. coli 0157:H7 and L. monocytogenes on milk agar supplemented with Purasal $\mathrm{Hi}$ Pure P Plus and incubated at $35^{\circ} \mathrm{C}$.

\begin{tabular}{lcccc}
\hline $\begin{array}{l}\text { Antimicrobial } \\
\text { Concentration }\end{array}$ & $\begin{array}{c}\text { Target Organism } \\
\text { Concentration } \\
\text { (CFU/ml) }\end{array}$ & $\begin{array}{c}\text { Time Until Observed Organism Growth } \\
\text { Salmonella }\end{array}$ & E. coli 0157:H7 & L. monocytogenes \\
\hline $0.02 \%$ & $5.0 \times 10^{1}$ & $24 \mathrm{~h}$ & $24 \mathrm{~h}$ & $24 \mathrm{~h}$ \\
& $5.0 \times 10^{2}$ & $24 \mathrm{~h}$ & $24 \mathrm{~h}$ & $24 \mathrm{~h}$ \\
& $5.0 \times 10^{4}$ & $24 \mathrm{~h}$ & $24 \mathrm{~h}$ & $24 \mathrm{~h}$ \\
$0.04 \%$ & $5.0 \times 10^{1}$ & $24 \mathrm{~h}$ & $24 \mathrm{~h}$ & $24 \mathrm{~h}$ \\
& $5.0 \times 10^{2}$ & $24 \mathrm{~h}$ & $24 \mathrm{~h}$ & $24 \mathrm{~h}$ \\
& $5.0 \times 10^{4}$ & $24 \mathrm{~h}$ & $24 \mathrm{~h}$ & $24 \mathrm{~h}$ \\
\hline
\end{tabular}


Table 4.14 Growth of Salmonella, E. coli 0157:H7 and L. monocytogenes on milk agar supplemented with PuraQ Verdad NV10 and incubated at $35^{\circ} \mathrm{C}$.

\begin{tabular}{lcccc}
\hline $\begin{array}{l}\text { Antimicrobial } \\
\text { Concentration }\end{array}$ & $\begin{array}{c}\text { Target Organism } \\
\text { Concentration } \\
\text { (CFU/ml) }\end{array}$ & Salmonella & E. coli 0157:H7 & L. monocytogenes \\
\hline \multirow{5}{*}{$0.02 \%$} & $5.0 \times 10^{1}$ & $24 \mathrm{~h}$ & $24 \mathrm{~h}$ & $48 \mathrm{~h}$ \\
& $5.0 \times 10^{2}$ & $24 \mathrm{~h}$ & $24 \mathrm{~h}$ & $48 \mathrm{~h}$ \\
& $5.0 \times 10^{4}$ & $24 \mathrm{~h}$ & $24 \mathrm{~h}$ & $48 \mathrm{~h}$ \\
$0.04 \%$ & & $24 \mathrm{~h}$ & $24 \mathrm{~h}$ & $48 \mathrm{~h}$ \\
& $5.0 \times 10^{1}$ & $24 \mathrm{~h}$ & $24 \mathrm{~h}$ & $48 \mathrm{~h}$ \\
& $5.0 \times 10^{2}$ & $24 \mathrm{~h}$ & $24 \mathrm{~h}$ & $48 \mathrm{~h}$ \\
\hline
\end{tabular}

Table 4.15 Growth of Salmonella, E. coli 0157:H7 and L. monocytogenes on milk agar supplemented with SaltWise 0029 and incubated at $35^{\circ} \mathrm{C}$.

\begin{tabular}{lcccc}
\hline $\begin{array}{l}\text { Antimicrobial } \\
\text { Concentration }\end{array}$ & $\begin{array}{c}\text { Target Organism } \\
\text { Concentration } \\
\text { (CFU/ml) }\end{array}$ & \multicolumn{3}{c}{ Time Until Observed Organism Growth } \\
& & & & \\
& $5.0 \times 10^{1}$ & $24 \mathrm{~h}$ & $24 \mathrm{~h}$ & $24 \mathrm{~h}$ \\
$1.0 \%$ & $5.0 \times 10^{2}$ & $24 \mathrm{~h}$ & $24 \mathrm{~h}$ & $24 \mathrm{~h}$ \\
& $5.0 \times 10^{4}$ & $24 \mathrm{~h}$ & $24 \mathrm{~h}$ & $24 \mathrm{~h}$ \\
& & & & \\
$2.0 \%$ & $5.0 \times 10^{1}$ & $24 \mathrm{~h}$ & $24 \mathrm{~h}$ & $24 \mathrm{~h}$ \\
& $5.0 \times 10^{2}$ & $24 \mathrm{~h}$ & $24 \mathrm{~h}$ & $24 \mathrm{~h}$ \\
& $5.0 \times 10^{4}$ & $24 \mathrm{~h}$ & $24 \mathrm{~h}$ & $24 \mathrm{~h}$ \\
& & & & \\
\end{tabular}

Table 4.16 Growth of Salmonella, E. coli 0157:H7 and L. monocytogenes on milk agar supplemented with SaltWise 1029 and incubated at $35^{\circ} \mathrm{C}$.

\begin{tabular}{lcccc}
\hline $\begin{array}{l}\text { Antimicrobial } \\
\text { Concentration }\end{array}$ & $\begin{array}{c}\text { Target Organism } \\
\text { Concentration } \\
\text { (CFU/ml) }\end{array}$ & Salmonella & E. coli 0157:H7 & L. monocytogenes \\
\hline \multirow{5}{*}{$\begin{array}{l} \\
5.0 \times 10^{1}\end{array}$} & $24 \mathrm{~h}$ & $24 \mathrm{~h}$ & $24 \mathrm{~h}$ \\
$1.0 \%$ & $5.0 \times 10^{2}$ & $24 \mathrm{~h}$ & $24 \mathrm{~h}$ & $24 \mathrm{~h}$ \\
& $5.0 \times 10^{4}$ & $24 \mathrm{~h}$ & $24 \mathrm{~h}$ & $24 \mathrm{~h}$ \\
& & & & \\
$2.0 \%$ & $5.0 \times 10^{1}$ & $24 \mathrm{~h}$ & $24 \mathrm{~h}$ & $24 \mathrm{~h}$ \\
& $5.0 \times 10^{2}$ & $24 \mathrm{~h}$ & $24 \mathrm{~h}$ & $24 \mathrm{~h}$ \\
& $5.0 \times 10^{4}$ & $24 \mathrm{~h}$ & $24 \mathrm{~h}$ & $24 \mathrm{~h}$ \\
\hline
\end{tabular}




\subsection{Discussion}

MicroGard 100 and MicroGard 430 provided partial to no inhibition of the organisms tested in milk agar. Specific antimicrobial mechanisms were discussed in Chapter 3. Despite changing the medium, the efficacy of MicroGard products was not improved. The $\mathrm{pH}$ of milk agar supplemented with MicroGard 100 averaged 6.7, while agar supplemented with MicroGard 430 ranged from 5.6 - 5.9. Both $\mathrm{pH}$ values are much higher than the propionic acid $\mathrm{pK}_{\mathrm{a}}$ values, which would reduce the efficacy of the organic acid.

Nisaplin, at the concentrations used in this study, delayed the growth of $L$. monocytogenes at the lower two inoculum levels in milk agar, but could not completely inhibit the organism. Previously, nisin was shown to be ineffective in preventing the growth of $L$. innocua in a dairy-based system (Staszewski and Jagus, 2008). Nisin initially reduced the count of the bacteria in liquid cheese whey ( $\mathrm{pH}$ 5.5); however, the initial decrease was followed by immediate regrowth of the bacteria. After $24 \mathrm{~h}$ of incubation at $25^{\circ} \mathrm{C}, L$. innocua cell density from whey treated with nisin was not significantly different from control samples. The authors hypothesized that the lack of antimicrobial effectiveness could be caused by the nonspecific binding of nisin to components of the milk agar. Additionally, the concentration of active bacteriocin in Nisaplin potentially affected efficacy. At the lower inoculum levels, the nisin concentration in milk agar was high enough to initially inhibit the growth. However, there was not enough active bacteriocin in the medium to continuously inhibit growth. 
VMY1P partially inhibited the growth of the three organisms tested. Though $\mathrm{pH}$ values in milk agar are similar to those in TSA, VMY1P provided inhibition in milk agar at concentrations where, in TSA, there had been no inhibition observed. TSA is an ideal medium for the growth of the microorganisms tested. Growth rates of the organisms in TSA most likely exceeded the degradation rates by the organic acids in VMY1P. However, milk agar, since it is not as ideal an environment as TSA, provided another microbial hurdle for microorganisms and potentially increased the efficacy of VMY1P.

The four antimicrobials that provided the most inhibition in TSA, NovaGard CB1, Protect-M, PuraQ Verdad RV75 and SEA-i F75, provided complete inhibition of the growth of E. coli O157:H7, Salmonella and L. monocytogenes in milk agar. Changing the food matrix enhanced the effectiveness of the antimicrobials; the increased complexity of the agar made the conditions less favorable for microbial growth. Under less favorable growth conditions, microbial growth rates slowed, allowing the antimicrobial system to work without being overwhelmed by rapid microbial growth. Mechanisms for each antimicrobial were detailed in Chapter 3. There was no antimicrobial activity of any of the sodium replacement agents detected in milk agar.

\subsection{Conclusion}

NovaGard CB1, Protect-M, PuraQ Verdad RV75 and SEA-i F75 were selected for further testing of antimicrobial efficacy in cheese agar and for potential antagonistic interactions with sodium replacement agents in milk agar. 


\subsection{Antimicrobial Efficacy Screening in Cheese Agar}

\subsection{Objectives}

To determine the antimicrobial efficacy of commercially available antimicrobials regular sodium and low sodium cheese agar.

\subsection{Hypothesis}

Antimicrobial efficacy will not be reduced in regular and low sodium cheese agars.

\subsection{Materials and Methods}

\subsubsection{Bacterial Strains}

Five strains of each E. coli O157:H7, Listeria monocytogenes and Salmonella were used in the study. E. coli O157:H7 strains NFPA 4212, NFPA 4213, NFPA 4216, NFPA 4217, and NFPA 4219 were obtained from the culture collection of the National Food Laboratory (Livermore, CA). Two of the Listeria monocytogenes strains, NFPA 6301 and NFPA 6306, were obtained from the culture collection of the National Food Laboratory (Livermore, CA) while the other three strains, NRRL B-33000, NRRL B-33096, and NRRL B-33113 were received from the National Center for Agricultural Utilization Research (Peoria, IL). Salmonella enterica strains, Salmonella Javiana FSL S5-406, Salmonella Enteriditis FSL S5-415, Salmonella Heidelburg FSL S5-448, Salmonella 
Oranienburg FSL S5-642, and Salmonella Typhimurium FSL W1-030, were obtained from the International Life Sciences Institute, North America (Cornell University, Ithaca, NY).

All strains were stored in cryogenic vials (Fisher Scientific, Hanover Park, IL) at $-70^{\circ} \mathrm{C}$ for long-term preservation. Prior to use, cultures were streaked on selective media and incubated at $35^{\circ} \mathrm{C}$ for $24 \mathrm{~h}$. Salmonella strains were streaked on Xylose Lysine Deoxycholate Agar (XLD, Neogen, Lansing, MI), while Modified Oxford Agar (MOX, Difco, Sparks, MD) was used for Listeria monocytogenes and MacConkey Agar with Sorbitol (SMAC, Neogen, Lansing, MI) was used for E. coli O157:H7. Isolated colonies were used for inoculum preparation.

\subsubsection{Preparation of Inocula}

Each strain was individually transferred into $10 \mathrm{ml}$ of Tryptic Soy Broth (TSB, Neogen, Lansing, Ml) and grown at $35^{\circ} \mathrm{C}$ for $18 \mathrm{~h}$. After incubation, equal volumes of each strain were pooled within a species to form a cocktail. Each cocktail was centrifuged (1,800 $\mathrm{g} \times 15 \mathrm{~min})$, washed twice with $0.1 \%$ peptone water and resuspended in $0.1 \%$ peptone water. Direct microscope count (DMC) was done with a Petroff-Hausser Counting Chamber (Hausser Scientific, Horsham, PA) to determine the initial stock concentration. Cocktails were diluted to the target concentration using $0.1 \%$ peptone water. Initial counts were confirmed by plating on Tryptic Soy Agar (TSA, Neogen, Lansing, MI) and incubating at $35^{\circ} \mathrm{C}$ for $24 \mathrm{~h}$. 


\subsubsection{Antimicrobials}

Four antimicrobials received from several suppliers were used in the study and consisted of NovaGard CB1, Protect-M, PuraQ Verdad RV 75 and SEA-i F75(Table 5.1). Antimicrobials were stored per manufacturer's recommendation until used in the study.

\subsubsection{Antimicrobial Efficacy Determination}

The efficacy of the antimicrobials in cheese agar was determined using an agar dilution method (Oussalah et al., 2007b). Cheese agar was prepared by adding $28 \mathrm{~g}$ of either regular sodium or low sodium low-moisture part-skim mozzarella to $300 \mathrm{ml}$ of sterile $1.5 \%$ agar. Cheese was melted and dispersed in the agar prior to the addition of antimicrobials. Antimicrobials were added to agar at one concentration; concentrations were determined using manufacturer recommendations and preliminary results in TSA and milk agar (Table 5.1). The supplemented agars were poured into sterile petri plates and allowed to solidify. Salmonella, L. monocytogenes or E. coli O157:H7 was spread plated onto solidified cheese agar at a target concentration of $10^{1}, 10^{2}$ and $10^{4} \mathrm{CFU} / \mathrm{ml}$. Uninoculated cheese agar plates served as negative controls while inoculated plates, without antimicrobial added, served as positive controls. Uninoculated supplemented agar plates were also tested for $\mathrm{pH}$. All test and control plates were incubated at $35^{\circ} \mathrm{C}$ for $48 \mathrm{~h}$. Plates were observed after $24 \mathrm{~h}$ and $48 \mathrm{~h}$ for presence or absence of growth. For all plates, absence of growth indicated the antimicrobial had an inhibitory effect. 
Table 5.1 Description and concentrations of antimicrobials used in antimicrobial efficacy screening in regular sodium and low sodium cheese agars.

\begin{tabular}{|c|c|c|c|}
\hline Antimicrobial & Manufacturer & Product Description & $\begin{array}{c}\text { Concentration Used } \\
(\%)\end{array}$ \\
\hline $\begin{array}{l}\text { NovaGard } \\
\text { CB1 }\end{array}$ & Danisco & $\begin{array}{l}\text { Maltodextrin; Cultured Dextrose; Sodium } \\
\text { Diacetate; NaCl; Lysozyme; Nisin }\end{array}$ & 1.0 \\
\hline Protect-M & Purac & Lauric Arginate & 0.20 \\
\hline $\begin{array}{l}\text { PuraQ Verdad } \\
\text { RV75 }\end{array}$ & Purac & $\begin{array}{c}\text { Cultured Sugar; Organic Acids; Residual } \\
\text { Sugars }\end{array}$ & 0.20 \\
\hline SEA-i F75 & Bienca & $\begin{array}{l}\text { Glucose; Glucose Oxidase; Whey; } \\
\text { Lactoperoxidase; Lactose; Casein }\end{array}$ & 0.25 \\
\hline
\end{tabular}

\subsection{Results}

\subsubsection{Efficacy of Antimicrobials against Salmonella, E. coli 0157:H7 and L. monocytogenes in Regular Sodium Cheese Agar.}

NovaGard CB1 and PuraQ Verdad RV75 completely inhibited the growth of E. coli O157:H7 and Salmonella at the lowest inoculum level (Table 5.2). All other test conditions with NovaGard CB1 and PuraQ Verdad RV75 yielded growth after $48 \mathrm{~h}$ of incubation. At an inoculum level of $10^{4} \mathrm{CFU} / \mathrm{ml}$, Protect-M provided no inhibition of the growth of E. coli O157:H7, L. monocytogenes or Salmonella. At an inoculum level of $10^{2} \mathrm{CFU} / \mathrm{ml}$, Protect-M still did not inhibit Salmonella, but it completely inhibited the growth of E. coli O157:H7 and L. monocytogenes. At an inoculum level of $10^{1} \mathrm{CFU} / \mathrm{ml}$, Protect-M delayed the growth of Salmonella and completely inhibited the growth E. coli $\mathrm{O} 157: \mathrm{H} 7$ and $L$ monocytogenes. SEA-i F75 provided complete inhibition of the three organisms 
tested in regular sodium cheese agar, regardless of the inoculum level (Table $5.2)$.

Table 5.2 Growth of Salmonella, E. coli 0157:H7 and L. monocytogenes at concentrations of 101, $10^{2}$ and $10^{4} \mathrm{CFU} / \mathrm{ml}$ on regular sodium cheese agar supplemented with various antimicrobials after incubation at $35^{\circ} \mathrm{C}$.

\begin{tabular}{lcccc}
\hline $\begin{array}{l}\text { Antimicrobial } \\
\text { (concentration) }\end{array}$ & $\begin{array}{c}\text { Target Inoculum } \\
\text { Level }\end{array}$ & \multicolumn{3}{c}{ Time Until Observed Organism Growth } \\
& & & & \\
& & & & \\
& $10^{1} \mathrm{CFU} / \mathrm{ml}$ & $\mathrm{NG} 1$ & $48 \mathrm{~h}$ & $48 \mathrm{~h}$ \\
NovaGard CB1 (1.0\%) & $10^{2} \mathrm{CFU} / \mathrm{ml}$ & $48 \mathrm{~h}$ & $48 \mathrm{~h}$ & $48 \mathrm{~h}$ \\
(pH 5.39) & $10^{4} \mathrm{CFU} / \mathrm{ml}$ & $48 \mathrm{~h}$ & $48 \mathrm{~h}$ & $48 \mathrm{~h}$ \\
& & & & \\
& $10^{1} \mathrm{CFU} / \mathrm{ml}$ & $48 \mathrm{~h}$ & $\mathrm{NG}$ & $\mathrm{NG}$ \\
Protect-M (0.2\%) & $10^{2} \mathrm{CFU} / \mathrm{ml}$ & $24 \mathrm{~h}$ & $\mathrm{NG}$ & $\mathrm{NG}$ \\
(pH 4.96) & $10^{4} \mathrm{CFU} / \mathrm{ml}$ & $24 \mathrm{~h}$ & $24 \mathrm{~h}$ & $24 \mathrm{~h}$ \\
& & & & \\
PuraQ Verdad RV75 & $10^{1} \mathrm{CFU} / \mathrm{ml}$ & $\mathrm{NG}$ & $48 \mathrm{~h}$ & $48 \mathrm{~h}$ \\
$(0.2 \%)$ & $10^{2} \mathrm{CFU} / \mathrm{ml}$ & $48 \mathrm{~h}$ & $48 \mathrm{~h}$ & $48 \mathrm{~h}$ \\
(pH 4.84) & $10^{4} \mathrm{CFU} / \mathrm{ml}$ & $48 \mathrm{~h}$ & $48 \mathrm{~h}$ & $48 \mathrm{~h}$ \\
& & & & \\
SEA-i F75 (0.25\%) & $10^{1} \mathrm{CFU} / \mathrm{ml}$ & $\mathrm{NG}$ & $\mathrm{NG}$ & $\mathrm{NG}$ \\
(pH 4.96) & $10^{2} \mathrm{CFU} / \mathrm{ml}$ & $\mathrm{NG}$ & $\mathrm{NG}$ & $\mathrm{NG}$ \\
& $10^{4} \mathrm{CFU} / \mathrm{ml}$ & $\mathrm{NG}$ & $\mathrm{NG}$ & $\mathrm{NG}$ \\
& & & & \\
\hline
\end{tabular}

NG: No growth detected after $48 \mathrm{~h}$ of incubation at $35^{\circ} \mathrm{C}$.

\subsubsection{Efficacy of Antimicrobials against Salmonella, E. coli O157:H7 and L. monocytogenes in Low Sodium Cheese Agar}

At an inoculum level of $10^{1} \mathrm{CFU} / \mathrm{ml}$, NovaGard CB1 provided complete inhibition of the growth of Salmonella, and delayed the growth of $L$. monocytogenes and E. coli O157:H7 (Table 5.3). At higher inoculum levels, the growth of Salmonella, L. monocytogenes and E. coli O157:H7 was delayed.

Protect-M completely inhibited the growth of Salmonella, L. monocytogenes, and E. coli $0157: \mathrm{H} 7$ at an inoculum level of $10^{1} \mathrm{CFU} / \mathrm{ml}$. At an inoculum level of $10^{2}$ 
CFU/ml, Protect-M provided complete inhibition of E. coli $\mathrm{O} 157: \mathrm{H} 7$ and $L$. momoncytogenes, but growth of Salmonella was detected after $48 \mathrm{~h}$. Growth of all three organisms was detected after $48 \mathrm{~h}$ at an inoculum level of $10^{4} \mathrm{CFU} / \mathrm{ml}$. At an inoculum level of $10^{1} \mathrm{CFU} / \mathrm{ml}$, PuraQ Verdad RV75 completely inhibited the growth of Salmonella and E. coli O157:H7 and delayed the growth of $L$.

monocytogenes. At higher inoculum levels, PuraQ Verdad RV75 delayed the growth of all three organisms. SEA-i F75 completely inhibited the growth of Salmonella and E. coli O157: $\mathrm{H} 7$ at inoculum levels of $10^{1}$ and $10^{2} \mathrm{CFU} / \mathrm{ml}$. At $10^{4} \mathrm{CFU} / \mathrm{ml}$, growth of both organisms was observed after 48 hours of incubation. SEA-i F75 completely inhibited the growth of $L$. monocytogenes at every inoculum level tested.

Table 5.3 Growth of Salmonella, E. coli 0157:H7 and L. monocytogenes at concentrations of 101, $10^{2}$ and $10^{4} \mathrm{CFU} / \mathrm{ml}$ on low sodium cheese agar supplemented with various antimicrobials after incubation at $35^{\circ} \mathrm{C}$.

\begin{tabular}{|c|c|c|c|c|}
\hline Antimicrobial & Target Inoculum & Time Ur & Observed Organi & rowth \\
\hline (concentration) & Level & Salmonella & E. coli 0157:H7 & Listeria \\
\hline & $10^{1} \mathrm{CFU} / \mathrm{ml}$ & NG1 & $48 \mathrm{~h}$ & $48 \mathrm{~h}$ \\
\hline NovaGard CB1 (1.0\%) & $10^{2} \mathrm{CFU} / \mathrm{ml}$ & $48 \mathrm{~h}$ & $48 \mathrm{~h}$ & $48 \mathrm{~h}$ \\
\hline & $10^{4} \mathrm{CFU} / \mathrm{ml}$ & $48 \mathrm{~h}$ & $48 \mathrm{~h}$ & $48 \mathrm{~h}$ \\
\hline & $10^{1} \mathrm{CFU} / \mathrm{ml}$ & NG & NG & NG \\
\hline Protect-M $(0.2 \%)$ & $10^{2} \mathrm{CFU} / \mathrm{ml}$ & $48 \mathrm{~h}$ & NG & NG \\
\hline & $10^{4} \mathrm{CFU} / \mathrm{ml}$ & $48 \mathrm{~h}$ & $48 \mathrm{~h}$ & $48 \mathrm{~h}$ \\
\hline PuraQ Verdad RV75 & $10^{1} \mathrm{CFU} / \mathrm{ml}$ & NG & NG & $48 \mathrm{~h}$ \\
\hline$(0.2 \%)$ & $10^{2} \mathrm{CFU} / \mathrm{ml}$ & $48 \mathrm{~h}$ & $48 \mathrm{~h}$ & $48 \mathrm{~h}$ \\
\hline (pH 4.87) & $10^{4} \mathrm{CFU} / \mathrm{ml}$ & $48 \mathrm{~h}$ & $48 \mathrm{~h}$ & $48 \mathrm{~h}$ \\
\hline & $10^{1} \mathrm{CFU} / \mathrm{ml}$ & NG & NG & NG \\
\hline (nH 4.94$)$ & $10^{2} \mathrm{CFU} / \mathrm{ml}$ & NG & NG & NG \\
\hline & $10^{4} \mathrm{CFU} / \mathrm{ml}$ & $48 \mathrm{~h}$ & $48 \mathrm{~h}$ & NG \\
\hline
\end{tabular}

NG: No growth detected after $48 \mathrm{~h}$ of incubation at $35^{\circ} \mathrm{C}$. 


\subsection{Discussion}

Efficacy of all four antimicrobials was reduced in cheese agars, as compared to milk agar (refer to Chapters 3 and 4 for results and antimicrobial mechanisms). NovaGard CB1 was able to delay the growth of all three organisms tested in regular sodium and low sodium cheese agar. Efficacy of lysozyme, a primary component of NovaGard CB1, can be limited by either the partial masking of the peptidoglycan substrate by cellular components or the incubation temperature (Hughey and Johnson, 1987). Because of the greater complexity, the components of the cheese agar potentially restricted access to the peptidoglycan, limiting adhesion sites for lysozyme to bind and reducing the enzyme antimicrobial efficacy. Additionally, the elevated incubation temperature allowed the rapidly growing cells to replenish the cells wall at rates much faster than the degradation of the cell wall by the lysozyme.

Protect-M was less effective in regular sodium cheese agar than in low sodium cheese agar. Potency of lauric arginate (LAE) can be affected by interactions with the food matrix. As a cationic surfactant, LAE may interact with anionic biopolymers in the food matrix through electrostatic interactions, causing reduction in activity (Asker et al., 2009). As the chloride concentration decreased, LAE activity increased, suggesting that there may be some interaction between LAE and the chloride in the cheese formulations.

Though there was not a major increase in $\mathrm{pH}$ (as compared to milk agar), decreases in the efficacy of PuraQ Verdad RV75 were observed in cheese agar. Though $\mathrm{pH}$ is the major determinant of antimicrobial activity for PuraQ Verdad 
RV75, competition for adhesion sites may have reduced efficacy. The increased agar complexity likely contributed to the reduction in antimicrobial efficacy.

The efficacy of SEA-i F75 was unchanged in regular sodium cheese agar, but decreased in low sodium cheese agar. Lactoperoxidase requires either thiocyanate or a halide, in addition to $\mathrm{H}_{2} \mathrm{O}_{2}$, in order to function as an antimicrobial. In the presence of a halide, the enzyme will forego its use of thiocyanate and rely solely on the halide to function (Boots and Floris, 2006). The decrease in activity in low sodium cheese agar indicates that chloride was contributing to the function of lactoperoxidase.

\subsection{Conclusion}

Efficacies of all four antimicrobials were reduced in cheese agar, as compared to milk agar. SEA-i F75 was the most effective antimicrobial in both cheese agars. In order to determine if there were any interaction between the antimicrobials and the sodium replacement agents, combinations were tested in milk agar, where the greatest antimicrobial efficacy was observed. 


\subsection{Antimicrobial and Sodium Replacement Agent Interaction Testing}

\subsection{Objectives}

To determine if sodium replacement agents would reduce antimicrobial efficacy in a dairy based system.

\subsection{Hypothesis}

There will be no reductions in the efficacy of antimicrobials when combined with sodium replacement agents.

\subsection{Materials and Methods}

\subsubsection{Bacterial Strains}

Five strains of each E. coli O157:H7, Listeria monocytogenes and Salmonella were used in the study. E. coli O157:H7 strains NFPA 4212, NFPA 4213, NFPA 4216, NFPA 4217, and NFPA 4219 were obtained from the culture collection of the National Food Laboratory (Livermore, CA). Two of the Listeria monocytogenes strains, NFPA 6301 and NFPA 6306, were obtained from the culture collection of the National Food Laboratory (Livermore, CA) while the other

three strains, NRRL B-33000, NRRL B-33096, and NRRL B-33113 were received from the National Center for Agricultural Utilization Research (Peoria, IL). Salmonella enterica strains, Salmonella Javiana FSL S5-406, Salmonella Enteriditis FSL S5-415, Salmonella Heidelburg FSL S5-448, Salmonella 
Oranienburg FSL S5-642, and Salmonella Typhimurium FSL W1-030, were obtained from the International Life Sciences Institute, North America (Cornell University, Ithaca, NY).

All strains were stored in cryogenic vials (Fisher Scientific, Hanover Park, IL) at $-70^{\circ} \mathrm{C}$ for long-term preservation. Prior to use, cultures were streaked on selective media and incubated at $35^{\circ} \mathrm{C}$ for $24 \mathrm{~h}$. Salmonella strains were streaked on Xylose Lysine Deoxycholate Agar (XLD, Neogen, Lansing, MI), while Modified Oxford Agar (MOX, Difco, Sparks, MD) was used for Listeria monocytogenes and MacConkey Agar with Sorbitol (SMAC, Neogen, Lansing, MI) was used for E. coli O157:H7. Isolated colonies were used for inoculum preparation.

\subsubsection{Preparation of Inocula}

Each strain was individually transferred into $10 \mathrm{ml}$ of Tryptic Soy Broth (TSB, Neogen, Lansing, Ml) and grown at $35^{\circ} \mathrm{C}$ for $18 \mathrm{~h}$. After incubation, equal volumes of each strain were pooled within a species to form a cocktail. Each cocktail was centrifuged (1,800 $\mathrm{g} \times 15 \mathrm{~min})$, washed twice with $0.1 \%$ peptone water and resuspended in $0.1 \%$ peptone water. Direct microscope count (DMC) was done with a Petroff-Hausser Counting Chamber (Hausser Scientific, Horsham, PA) to determine the initial stock concentration. Cocktails were diluted to the target concentration using $0.1 \%$ peptone water. Initial counts were confirmed by plating on Tryptic Soy Agar (TSA, Neogen, Lansing, MI) and incubating at $35^{\circ} \mathrm{C}$ for $24 \mathrm{~h}$. 


\subsubsection{Antimicrobials and Sodium Replacement Agents.}

Four antimicrobials received from several suppliers were used in the study and consisted of NovaGard CB1, Protect-M, PuraQ Verdad RV 75 and SEA-i F75 (Table 6.1). Eight sodium replacement agents received from several suppliers were also used in the study (Table 2). These included Alta 2345, potassium chloride, Puracal PP/USP, PuraQ Verdad NV10, Purasal Hi Pure P Plus, Salona, SaltWise 0029 and SaltWise 1029. Antimicrobials and sodium replacement agents were stored per manufacturer's recommendation until used in the study.

\subsubsection{Antimicrobial Interaction Testing.}

An agar dilution method was used to test for an interaction between antimicrobials and sodium replacement agents in TSA and milk agar (Oussalah et al., 2007b). TSA was prepared per manufacturer's preparation instructions, then adjusted to $\mathrm{pH} 5.8$ using $1 \mathrm{~N} \mathrm{HCl}$. Milk agar was prepared by dissolving nonfat dry milk $(8 \mathrm{~g} / \mathrm{L})$ and agar $(15 \mathrm{~g} / \mathrm{L})$ in deionized water. Agar was autoclaved at $121^{\circ} \mathrm{C}$ for 15 minutes then tempered prior to use. One concentration of each antimicrobial was added to either TSA or milk agar. Sodium replacement agents were then added to supplemented agar at one or two concentrations (Tables 6.1 and 6.2). TSA and milk agar, supplemented with a sodium replacement agent and an antimicrobial, were poured into sterile petri plates and allowed to solidify. Concentrations used for each antimicrobial and sodium replacement agent were determined using manufacturer 
recommendations and preliminary antimicrobial efficacy results in TSA and milk agar.

Salmonella, L. monocytogenes or E. coli O157:H7 was spread plated onto solidified TSA or milk agar at a target concentration of $10^{4} \mathrm{CFU} / \mathrm{ml}$. Uninoculated TSA and milk agar plates served as negative controls while inoculated plates, without antimicrobial added, served as positive controls. All test and control plates were incubated at $35^{\circ} \mathrm{C}$ for $48 \mathrm{~h}$. Plates were observed after $24 \mathrm{~h}$ and 48 $\mathrm{h}$ for presence or absence of growth. For all plates, a change in growth, as compared to previous antimicrobial results without salt substitutes, indicated an interaction between the antimicrobial and the sodium reduction agent.

Table 6.1 Description and concentrations of antimicrobials used in interaction testing in TSA and milk agar.

\begin{tabular}{|c|c|c|c|}
\hline Antimicrobial & Manufacturer & Product Description & $\begin{array}{c}\text { Concentration Used } \\
(\%)\end{array}$ \\
\hline $\begin{array}{l}\text { NovaGard } \\
\text { CB1 }\end{array}$ & Danisco & $\begin{array}{l}\text { Maltodextrin; Cultured Dextrose; Sodium } \\
\text { Diacetate; NaCl; Lysozyme; Nisin }\end{array}$ & 1.0 \\
\hline Protect-M & Purac & Lauric Arginate & 0.20 \\
\hline $\begin{array}{l}\text { PuraQ Verdad } \\
\text { RV75 }\end{array}$ & Purac & $\begin{array}{c}\text { Cultured Sugar; Organic Acids; Residual } \\
\text { Sugars }\end{array}$ & 0.20 \\
\hline SEA-i F75 & Bienca & $\begin{array}{l}\text { Glucose; Glucose Oxidase; Whey; } \\
\text { Lactoperoxidase; Lactose; Casein }\end{array}$ & 0.25 \\
\hline
\end{tabular}


Table 6.2 Description and concentrations of sodium replacement agents used in interaction testing in TSA and milk agar.

\begin{tabular}{|c|c|c|c|c|c|}
\hline \multirow{2}{*}{$\begin{array}{l}\text { Sodium } \\
\text { Replacement Agents }\end{array}$} & \multirow{2}{*}{$\begin{array}{c}\text { Manufacture } \\
r\end{array}$} & \multirow{2}{*}{ Product Description } & \multicolumn{3}{|c|}{$\begin{array}{c}\text { Concentrations Used } \\
(\%)\end{array}$} \\
\hline & & & TSA & & Agar \\
\hline Alta 2345 & Kerry & Yeast Extract & 0.25 & 0.25 & \\
\hline Potassium Chloride & Cargill & Potassium chloride & 2.0 & 1.0 & 2.0 \\
\hline Puracal PP/USP & Purac & Calcium lactate & 0.04 & 0.02 & 0.04 \\
\hline $\begin{array}{l}\text { Purasal Hi Pure P } \\
\text { Plus }\end{array}$ & Purac & Potassium lactate & 0.04 & 0.02 & 0.04 \\
\hline PuraQ Verdad NV10 & Purac & Cultured corn sugar & 0.04 & 0.02 & 0.04 \\
\hline Salona & BK Giulini & $\begin{array}{l}\text { Reduced sodium sea salt from Dead } \\
\text { Sea }\end{array}$ & 0.95 & 0.95 & \\
\hline SaltWise 0029 & Cargill & $\begin{array}{l}\text { Potassium chloride; trehalose; } \\
\text { autolyzed yeast extract; silicon } \\
\text { dioxide }\end{array}$ & 2.0 & 1.0 & 2.0 \\
\hline SaltWise 1029 & Cargill & $\begin{array}{l}\text { Potassium chloride; trehalose; } \\
\text { autolyzed yeast extract; silicon } \\
\text { dioxide }\end{array}$ & 2.0 & 1.0 & 2.0 \\
\hline
\end{tabular}

\subsection{Results}

\subsubsection{NovaGard CB1}

Results in TSA showed that NovaGard CB1 alone could not inhibit the growth of the three organisms tested (Table 6.3). When combined with sodium replacement agents that did not contain $\mathrm{KCl}$, antimicrobial efficacy of NovaGard CB1 increased. In milk agar, NovaGard CB1 completely inhibited the growth of 
the three organisms tested when no sodium replacement agent was added (Table 6.4). Reductions in efficacy were observed when NovaGard CB1 was combined with sodium replacement agents that contained $\mathrm{KCl}$.

\subsubsection{Protect-M.}

Growth of all three organisms was completely inhibited in TSA supplemented with Protect-M and any of the sodium replacement agents used (Table 6.5). In milk agar, L. monoycytogenes growth was completely inhibited by Protect-M, regardless of the sodium replacement agent combination (Table 6.6). The antimicrobial efficacy of Protect-M against E. coli O157:H7 remained the same when the antimicrobial was combined with Alta 2345 and the lowest concentration of $\mathrm{KCl}$. All other test conditions eventually yielded growth of the organism. Inhibition of Salmonella was only observed when Protect-M was combined with the lowest concentration of $\mathrm{KCl}$. Growth was observed in all other test conditions within $48 \mathrm{~h}$.

\subsubsection{PuraQ Verdad RV75}

Antimicrobial efficacy of PuraQ Verdad RV75 in TSA was not affected by the addition of sodium replacement agents; growth was still observed after $24 \mathrm{~h}$ of incubation (Table 6.7). In milk agar, L. monoycytogenes growth was completely inhibited by PuraQ Verdad RV75, regardless of the sodium replacement agent combination (Table 6.8). Decreases in efficacy of PuraQ Verdad RV75 against E. coli O157:H7 were observed when the antimicrobial was 
tested in combination with Purasal Hi Pure P Plus. All other conditions yielded growth of E. coli O157:H7 within $48 \mathrm{~h}$. Growth of Salmonella was not observed when PuraQ Verdad RV75 was tested in combination with Salona. However, when combined with any of the other sodium replacement agents, antimicrobial activity was reduced.

\subsubsection{SEA-i F75}

No growth of any of the organisms tested was observed in TSA or milk agar supplemented with SEA-i F75 and any of the sodium replacement agents (Tables 6.9 and 6.10).

Table 6.3 Growth of Salmonella, E. coli 0157:H7 and L. monocytogenes at concentrations of $10^{4}$ $\mathrm{CFU} / \mathrm{ml}$ on TSA (pH 5.8) supplemented with NovaGard CB1 at a concentration of $1.0 \%$ and various sodium replacement agents after incubation at $35^{\circ} \mathrm{C}$.

\begin{tabular}{lcccc}
\hline \multicolumn{2}{c}{$\begin{array}{c}\text { Sodium Replacement Agent } \\
\text { Concentration } \\
\text { Name }\end{array}$} & $\begin{array}{c}\text { Time Until Observed Organism Growth } \\
\text { Salmonella }\end{array}$ & E. coli O157:H7 & $\begin{array}{c}\text { L. } \\
\text { monocytogenes }\end{array}$ \\
\hline No Sodium Replacer & NA & $24 \mathrm{~h}$ & $24 \mathrm{~h}$ & $24 \mathrm{~h}$ \\
Alta 2345 & 0.25 & $48 \mathrm{~h}$ & $24 \mathrm{~h}$ & $48 \mathrm{~h}$ \\
Potassium Chloride & 2.0 & $24 \mathrm{~h}$ & $24 \mathrm{~h}$ & $24 \mathrm{~h}$ \\
Puracal PP/USP & 0.04 & $48 \mathrm{~h}$ & $48 \mathrm{~h}$ & $48 \mathrm{~h}$ \\
$\begin{array}{l}\text { Purasal Hi Pure P } \\
\text { Plus }\end{array}$ & 0.04 & NG & NG & NG \\
PuraQ Verdad NV10 & 0.04 & $48 \mathrm{~h}$ & $48 \mathrm{~h}$ & $48 \mathrm{~h}$ \\
Salona & 0.95 & $48 \mathrm{~h}$ & $24 \mathrm{~h}$ & $48 \mathrm{~h}$ \\
SaltWise 0029 & 2.0 & $24 \mathrm{~h}$ & $24 \mathrm{~h}$ & $24 \mathrm{~h}$ \\
SaltWise 1029 & 2.0 & $24 \mathrm{~h}$ & $24 \mathrm{~h}$ & $24 \mathrm{~h}$ \\
\hline
\end{tabular}


Table 6.4 Growth of Salmonella, E. coli 0157:H7 and L. monocytogenes at concentrations of $10^{4}$ CFU/ml on milk agar supplemented with NovaGard CB1 at a concentration of $1.0 \%$ and various sodium replacement agents after incubation at $35^{\circ} \mathrm{C}$.

\begin{tabular}{|c|c|c|c|c|}
\hline \multicolumn{2}{|c|}{ Sodium Replacement Agent } & \multicolumn{3}{|c|}{ Time Until Observed Organism Growth } \\
\hline Name & $\begin{array}{c}\text { Concentration } \\
(\%)\end{array}$ & Salmonella & E. coli 0157:H7 & $\begin{array}{c}L . \\
\text { monocytogenes }\end{array}$ \\
\hline $\begin{array}{l}\text { No Sodium } \\
\text { Replacer }\end{array}$ & NA & NG1 & NG & NG \\
\hline Alta 2345 & 0.25 & NG1 & NG & NG \\
\hline Potassium Chloride & $\begin{array}{l}1.0 \\
2.0\end{array}$ & $\begin{array}{l}N G \\
24 \mathrm{~h}\end{array}$ & $\begin{array}{l}N G \\
24 \mathrm{~h}\end{array}$ & $\begin{array}{l}\text { NG } \\
\text { NG }\end{array}$ \\
\hline Puracal PP/USP & $\begin{array}{l}0.02 \\
0.04\end{array}$ & $\begin{array}{l}N G \\
N G\end{array}$ & $\begin{array}{l}\text { NG } \\
\text { NG }\end{array}$ & $\begin{array}{l}\text { NG } \\
\text { NG }\end{array}$ \\
\hline $\begin{array}{l}\text { Purasal Hi Pure P } \\
\text { Plus }\end{array}$ & $\begin{array}{l}0.02 \\
0.04\end{array}$ & $\begin{array}{l}\text { NG } \\
\text { NG }\end{array}$ & $\begin{array}{l}\text { NG } \\
\text { NG }\end{array}$ & $\begin{array}{l}\text { NG } \\
\text { NG }\end{array}$ \\
\hline $\begin{array}{l}\text { PuraQ Verdad } \\
\text { NV10 }\end{array}$ & $\begin{array}{l}0.02 \\
0.04\end{array}$ & $\begin{array}{l}\text { NG } \\
\text { NG }\end{array}$ & $\begin{array}{l}\text { NG } \\
\text { NG }\end{array}$ & $\begin{array}{l}\text { NG } \\
\text { NG }\end{array}$ \\
\hline Salona & 0.95 & NG & NG & NG \\
\hline SaltWise 0029 & $\begin{array}{l}1.0 \\
2.0\end{array}$ & $\begin{array}{l}N G \\
24 h\end{array}$ & $\begin{array}{l}N G \\
24 \mathrm{~h}\end{array}$ & $\begin{array}{l}\text { NG } \\
\text { NG }\end{array}$ \\
\hline SaltWise 1029 & $\begin{array}{l}1.0 \\
2.0\end{array}$ & $\begin{array}{l}N G \\
24 \mathrm{~h}\end{array}$ & $\begin{array}{l}N G \\
24 \mathrm{~h}\end{array}$ & $\begin{array}{l}\text { NG } \\
\text { NG }\end{array}$ \\
\hline
\end{tabular}

1NG: No growth detected after 48 hours of incubation at $35^{\circ} \mathrm{C}$. 
Table 6.5 Growth of Salmonella, E. coli 0157:H7 and L. monocytogenes at concentrations of $10^{4}$ $\mathrm{CFU} / \mathrm{ml}$ on TSA (pH 5.8) supplemented with Protect-M at a concentration of $0.2 \%$ and various sodium replacement agents after incubation at $35^{\circ} \mathrm{C}$.

\begin{tabular}{|c|c|c|c|c|}
\hline \multicolumn{2}{|c|}{ Sodium Replacement Agent } & \multicolumn{3}{|c|}{ Time Until Observed Organism Growth } \\
\hline Name & $\begin{array}{c}\text { Concentration } \\
(\%)\end{array}$ & Salmonella & E. coli 0157:H7 & $\begin{array}{c}L . \\
\text { monocytogenes }\end{array}$ \\
\hline No Sodium Replacer & NA & $N G^{1}$ & NG & NG \\
\hline Alta 2345 & 0.25 & NG & NG & NG \\
\hline Potassium Chloride & 2.0 & NG & NG & NG \\
\hline Puracal PP/USP & 0.04 & NG & NG & NG \\
\hline $\begin{array}{l}\text { Purasal Hi Pure P } \\
\text { Plus }\end{array}$ & 0.04 & NG & NG & NG \\
\hline PuraQ Verdad NV10 & 0.04 & NG & NG & NG \\
\hline Salona & 0.95 & NG & $N G$ & NG \\
\hline SaltWise 0029 & 2.0 & NG & NG & NG \\
\hline SaltWise 1029 & 2.0 & NG & NG & NG \\
\hline
\end{tabular}

${ }^{1} \mathrm{NG}$ : No growth detected after 48 hours of incubation at $35^{\circ} \mathrm{C}$. 
Table 6.6 Growth of Salmonella, E. coli 0157:H7 and L. monocytogenes at concentrations of $10^{4}$ $\mathrm{CFU} / \mathrm{ml}$ on milk agar supplemented with Protect-M at a concentration of $0.2 \%$ and various sodium replacement agents after incubation at $35^{\circ} \mathrm{C}$.

\begin{tabular}{|c|c|c|c|c|}
\hline \multicolumn{2}{|c|}{ Sodium Replacement Agent } & \multicolumn{3}{|c|}{ Time Until Observed Organism Growth } \\
\hline Name & Concentration (\%) & Salmonella & $\begin{array}{l}\text { E. coli } \\
\text { 0157:H7 }\end{array}$ & $\begin{array}{c}L . \\
\text { monocytogenes }\end{array}$ \\
\hline $\begin{array}{l}\text { No Sodium } \\
\text { Replacer }\end{array}$ & NA & $N^{1}$ & NG & NG \\
\hline Alta 2345 & 0.25 & $48 \mathrm{~h}$ & NG & NG \\
\hline Potassium Chloride & $\begin{array}{l}1.0 \\
2.0\end{array}$ & $\begin{array}{l}N G \\
24 \mathrm{~h}\end{array}$ & $\begin{array}{l}N G \\
48 \mathrm{~h}\end{array}$ & $\begin{array}{l}\text { NG } \\
\text { NG }\end{array}$ \\
\hline Puracal PP/USP & $\begin{array}{l}0.02 \\
0.04\end{array}$ & $\begin{array}{l}24 \mathrm{~h} \\
24 \mathrm{~h}\end{array}$ & $\begin{array}{l}24 \mathrm{~h} \\
24 \mathrm{~h}\end{array}$ & $\begin{array}{l}\text { NG } \\
\text { NG }\end{array}$ \\
\hline $\begin{array}{l}\text { Purasal Hi Pure P } \\
\text { Plus }\end{array}$ & $\begin{array}{l}0.02 \\
0.04\end{array}$ & $\begin{array}{l}24 \mathrm{~h} \\
24 \mathrm{~h}\end{array}$ & $\begin{array}{l}24 \mathrm{~h} \\
24 \mathrm{~h}\end{array}$ & $\begin{array}{l}\text { NG } \\
\text { NG }\end{array}$ \\
\hline $\begin{array}{l}\text { PuraQ Verdad } \\
\text { NV10 }\end{array}$ & $\begin{array}{l}0.02 \\
0.04\end{array}$ & $\begin{array}{l}24 \mathrm{~h} \\
24 \mathrm{~h}\end{array}$ & $\begin{array}{l}24 \mathrm{~h} \\
24 \mathrm{~h}\end{array}$ & $\begin{array}{l}\text { NG } \\
\text { NG }\end{array}$ \\
\hline Salona & 0.95 & $24 \mathrm{~h}$ & $24 \mathrm{~h}$ & NG \\
\hline SaltWise 0029 & $\begin{array}{l}1.0 \\
2.0\end{array}$ & $\begin{array}{l}24 \mathrm{~h} \\
24 \mathrm{~h}\end{array}$ & $\begin{array}{l}24 \mathrm{~h} \\
48 \mathrm{~h}\end{array}$ & $\begin{array}{l}\text { NG } \\
\text { NG }\end{array}$ \\
\hline SaltWise 1029 & $\begin{array}{l}1.0 \\
2.0\end{array}$ & $\begin{array}{l}24 \mathrm{~h} \\
24 \mathrm{~h}\end{array}$ & $\begin{array}{l}24 \mathrm{~h} \\
48 \mathrm{~h}\end{array}$ & $\begin{array}{l}\text { NG } \\
\text { NG }\end{array}$ \\
\hline
\end{tabular}

${ }^{1} \mathrm{NG}$ : No growth detected after 48 hours of incubation at $35^{\circ} \mathrm{C}$. 
Table 6.7 Growth of Salmonella, E. coli 0157:H7 and L. monocytogenes at concentrations of $10^{4}$ CFU/ml on TSA (pH 5.8) supplemented with PuraQ Verdad RV75 at a concentration of $0.2 \%$ and various sodium replacement agents after incubation at $35^{\circ} \mathrm{C}$.

\begin{tabular}{lcccc}
\hline \multicolumn{2}{c}{$\begin{array}{c}\text { Sodium Replacement Agent } \\
\text { Concentration } \\
(\%)\end{array}$} & $\begin{array}{c}\text { Time Until Observed Organism Growth } \\
\text { Salmonella }\end{array}$ & $\begin{array}{c}\text { E. coli O157:H7 } \\
\text { monocytogenes }\end{array}$ \\
\hline No Sodium Replacer & NA & $24 \mathrm{~h}$ & $24 \mathrm{~h}$ & $24 \mathrm{~h}$ \\
Alta 2345 & 0.25 & $24 \mathrm{~h}$ & $24 \mathrm{~h}$ & $24 \mathrm{~h}$ \\
Potassium Chloride & 2.0 & $24 \mathrm{~h}$ & $24 \mathrm{~h}$ & $24 \mathrm{~h}$ \\
Puracal PP/USP & 0.04 & $24 \mathrm{~h}$ & $24 \mathrm{~h}$ & $24 \mathrm{~h}$ \\
$\begin{array}{l}\text { Purasal Hi Pure P } \\
\text { Plus }\end{array}$ & 0.04 & $24 \mathrm{~h}$ & $24 \mathrm{~h}$ & $24 \mathrm{~h}$ \\
PuraQ Verdad NV10 & 0.04 & $24 \mathrm{~h}$ & $24 \mathrm{~h}$ & $24 \mathrm{~h}$ \\
Salona & 0.95 & $24 \mathrm{~h}$ & $24 \mathrm{~h}$ & $24 \mathrm{~h}$ \\
SaltWise 0029 & 2.0 & $24 \mathrm{~h}$ & $24 \mathrm{~h}$ & $24 \mathrm{~h}$ \\
SaltWise 1029 & 2.0 & $24 \mathrm{~h}$ & $24 \mathrm{~h}$ & $24 \mathrm{~h}$ \\
\hline
\end{tabular}

${ }^{1} \mathrm{NG}$ : No growth detected after 48 hours of incubation at $35^{\circ} \mathrm{C}$. 
Table 6.8 Growth of Salmonella, E. coli 0157:H7 and L. monocytogenes at concentrations of $10^{4}$ $\mathrm{CFU} / \mathrm{ml}$ on milk agar supplemented with PuraQ Verdad RV75 at a concentration of $0.2 \%$ and various sodium replacement agents after incubation at $35^{\circ} \mathrm{C}$.

\begin{tabular}{|c|c|c|c|c|}
\hline \multicolumn{2}{|c|}{ Sodium Replacement Agent } & \multicolumn{3}{|c|}{ Time Until Observed Organism Growth } \\
\hline Name & $\begin{array}{c}\text { Concentration } \\
(\%)\end{array}$ & Salmonella & E. coli 0157:H7 & $\begin{array}{c}L . \\
\text { monocytogenes }\end{array}$ \\
\hline $\begin{array}{l}\text { No Sodium } \\
\text { Replacer }\end{array}$ & NA & NG & NG & NG \\
\hline Alta 2345 & 0.25 & $48 \mathrm{~h}$ & $48 \mathrm{~h}$ & NG1 \\
\hline Potassium Chloride & $\begin{array}{l}1.0 \\
2.0\end{array}$ & $\begin{array}{l}48 \mathrm{~h} \\
24 \mathrm{~h}\end{array}$ & $\begin{array}{l}N G \\
24 \mathrm{~h}\end{array}$ & $\begin{array}{l}N G \\
N G\end{array}$ \\
\hline Puracal PP/USP & $\begin{array}{l}0.02 \\
0.04\end{array}$ & $\begin{array}{l}48 \mathrm{~h} \\
48 \mathrm{~h}\end{array}$ & $\begin{array}{l}N G \\
48 \mathrm{~h}\end{array}$ & $\begin{array}{l}N G \\
N G\end{array}$ \\
\hline $\begin{array}{l}\text { Purasal Hi Pure P } \\
\text { Plus }\end{array}$ & $\begin{array}{l}0.02 \\
0.04\end{array}$ & $\begin{array}{l}48 \mathrm{~h} \\
48 \mathrm{~h}\end{array}$ & $\begin{array}{l}N G \\
N G\end{array}$ & $\begin{array}{l}N G \\
N G\end{array}$ \\
\hline $\begin{array}{l}\text { PuraQ Verdad } \\
\text { NV10 }\end{array}$ & $\begin{array}{l}0.02 \\
0.04\end{array}$ & $\begin{array}{l}48 \mathrm{~h} \\
48 \mathrm{~h}\end{array}$ & $\begin{array}{l}N G \\
48 \mathrm{~h}\end{array}$ & $\begin{array}{l}N G \\
N G\end{array}$ \\
\hline Salona & 0.95 & NG & $48 \mathrm{~h}$ & NG \\
\hline SaltWise 0029 & $\begin{array}{l}1.0 \\
2.0\end{array}$ & $\begin{array}{l}48 \mathrm{~h} \\
24 \mathrm{~h}\end{array}$ & $\begin{array}{l}N G \\
24 \mathrm{~h}\end{array}$ & $\begin{array}{l}N G \\
N G\end{array}$ \\
\hline SaltWise 1029 & $\begin{array}{l}1.0 \\
2.0\end{array}$ & $\begin{array}{l}48 \mathrm{~h} \\
24 \mathrm{~h}\end{array}$ & $\begin{array}{l}N G \\
24 \mathrm{~h}\end{array}$ & $\begin{array}{l}N G \\
N G\end{array}$ \\
\hline
\end{tabular}

${ }^{1}$ NG: No growth detected after 48 hours of incubation at $35^{\circ} \mathrm{C}$. 
Table 6.9 Growth of Salmonella, E. coli 0157:H7 and L. monocytogenes at concentrations of $10^{4}$ $\mathrm{CFU} / \mathrm{ml}$ on TSA (pH 5.8) supplemented with SEA-i F75 at a concentration of $0.25 \%$ and various sodium replacement agents after incubation at $35^{\circ} \mathrm{C}$.

\begin{tabular}{lcccc}
\hline \multicolumn{2}{c}{$\begin{array}{c}\text { Sodium Replacement Agent } \\
\text { Concentration } \\
\text { Name }\end{array}$} & $\begin{array}{c}\text { Time Until Observed Organism Growth } \\
\text { Salmonella }\end{array}$ & E. coli O157:H7 & $\begin{array}{c}\text { L. } \\
\text { monocytogenes }\end{array}$ \\
\hline No Sodium Replacer & NA & NG & NG & NG \\
Alta 2345 & 0.25 & NG & NG & NG \\
Potassium Chloride & 2.0 & NG & NG & NG \\
Puracal PP/USP & 0.04 & NG & NG & NG \\
$\begin{array}{l}\text { Purasal Hi Pure P } \\
\text { Plus }\end{array}$ & 0.04 & NG & NG & NG \\
PuraQ Verdad NV10 & 0.04 & NG & NG & NG \\
Salona & 0.95 & NG & NG & NG \\
SaltWise 0029 & 2.0 & NG & NG & NG \\
SaltWise 1029 & 2.0 & NG & NG & NG \\
\hline
\end{tabular}

${ }^{1} \mathrm{NG}$ : No growth detected after 48 hours of incubation at $35^{\circ} \mathrm{C}$. 
Table 6.10 Growth of Salmonella, E. coli 0157:H7 and L. monocytogenes at concentrations of $10^{4}$ $\mathrm{CFU} / \mathrm{ml}$ on milk agar supplemented with SEA-i F75 at a concentration of $0.25 \%$ and various sodium replacement agents after incubation at $35^{\circ} \mathrm{C}$.

\begin{tabular}{lcccc}
\hline \multicolumn{1}{c}{$\begin{array}{c}\text { Sodium Replacement Agent } \\
\text { Concentration } \\
\text { Name }\end{array}$} & $\begin{array}{c}\text { Time Until Observed Organism Growth } \\
\text { Salmonella }\end{array}$ & E. coli O157:H7 & $\begin{array}{c}\text { L. } \\
\text { monocytogenes }\end{array}$ \\
$\begin{array}{l}\text { No Sodium } \\
\text { Replacer }\end{array}$ & NA & NG & NG & NG \\
Alta 2345 & 0.25 & NG & NG & NG \\
Potassium Chloride & 1.0 & NG & NG & NG \\
& 2.0 & NG & NG & NG \\
Puracal PP/USP & 0.02 & NG & NG & NG \\
Purasal Hi Pure P & 0.04 & NG & NG & NG \\
Plus & 0.02 & NG & NG & NG \\
PuraQ Verdad & 0.04 & NG & NG & NG \\
NV10 & 0.02 & NG & NG & NG \\
Salona & 0.04 & NG & NG & NG \\
SaltWise 0029 & 0.95 & NG & NG & NG \\
& 1.0 & NG & NG & NG \\
SaltWise 1029 & 2.0 & NG & NG & NG \\
& 1.0 & NG & NG & NG \\
\hline
\end{tabular}

${ }^{1}$ NG: No growth detected after 48 hours of incubation at $35^{\circ} \mathrm{C}$. 


\subsection{Discussion}

There was no reduction in the antimicrobial efficacy of NovaGard CB1 in TSA when combined with any of the sodium replacement agents. The antimicrobial efficacy of NovaGard CB1 was reduced by sodium replacement agents that contained $\mathrm{KCl}$ in milk agar. Efficacy of lysozyme, one of the major antimicrobial components of NovaGard CB1, can be reduced with increases in cation concentrations (Branen and Davidson, 2004). It is reasonable to assume that the changes in efficacy were caused by interactions between the lysozyme in the NovaGard and potassium chloride. The increase in $\mathrm{K}^{+}$concentration in the agar systems potentially reduced the efficacy of NovaGard CB1.

Although no decreases in the efficacy of Protect-M were observed in TSA, efficacy against Salmonella and E. coli O157:H7 was reduced in milk agar. Potency of LAE can be reduced in the presence of anionic biopolymers (Rodriguez et al, 2004). Salts, lactates and other organic acids could potentially dissociate in agar and produce anionic biopolymers. Interactions between these anionic components and LAE potentially led to reductions in efficacy.

Though antimicrobial activity of Pura Verdad RV75 relies heavily on the $\mathrm{pH}$ value, the $\mathrm{pH}$ value did not vary greatly between milk agars supplemented with PuraQ Verdad RV75 and sodium replacement agents (data not shown). Therefore differences in antimicrobial activity cannot be attributed to differences in $\mathrm{pH}$. Sodium replacement agents could have potentially obstructed access of PuraQ Verdad RV75 to adhesion sites on the cellular membrane, thereby reducing antimicrobial efficacy. 
There were no antagonistic interactions between SEA-i F75 and any of the sodium replacement agents observed. No decreases in antimicrobial activity were detected regardless of the combination. Antimicrobial activity of SEA-i F75 depends on the presence of hydrogen peroxide and the concentration of thiocyanate in the milk agar, which do not change with the addition of sodium replacement agents.

\subsection{Conclusion}

SEA-i F75 was the only antimicrobial tested whose efficacy was not reduced with the addition of a sodium replacement agent. The overall effectiveness of SEA-i F75 in different media led to the selection of this antimicrobial for use in a low sodium low-moisture part-skim (LMPS) mozzarella cheese. 


\subsection{Final Cheese Challenge}

\subsection{Objective}

To determine the fate of Salmonella, Listeria monocytogenes and E. coli 0157:H7 in six formulations of artificially inoculated regular sodium and low sodium low-moisture part-skim (LMPS) mozzarella string cheese with and without the addition of sodium replacements and SEA-i F75.

\subsection{Hypothesis}

SEA-i F75 will inhibit the growth of Salmonella, L. monocytogenes and E. coli $\mathrm{O} 157: \mathrm{H} 7$ in all formulations tested during incubation at $4^{\circ}$ and $12^{\circ} \mathrm{C}$ for 30 and 90 days, respectively.

\subsection{Materials and Methods}

\subsubsection{Bacterial Strains}

Five strains of each E. coli O157:H7, Listeria monocytogenes and Salmonella were used in the study. E. coli O157:H7 strains NFPA 4212, NFPA 4213, NFPA 4216, NFPA 4217, and NFPA 4219 were obtained from the culture collection of the National Food Laboratory (Livermore, CA). Two of the Listeria monocytogenes strains, NFPA 6301 and NFPA 6306, were obtained from the culture collection of the National Food Laboratory (Livermore, CA) while the other

three strains, NRRL B-33000, NRRL B-33096, and NRRL B-33113 were received 
from the National Center for Agricultural Utilization Research (Peoria, IL). Salmonella enterica strains, Salmonella Javiana FSL S5-406, Salmonella Enteriditis FSL S5-415, Salmonella Heidelburg FSL S5-448, Salmonella Oranienburg FSL S5-642, and Salmonella Typhimurium FSL W1-030, were obtained from the International Life Sciences Institute, North America (Cornell University, Ithaca, NY).

All strains were stored in cryogenic vials (Fisher Scientific, Hanover Park, IL) at $-70^{\circ} \mathrm{C}$ for long-term preservation. Prior to use, cultures were streaked on selective media and incubated at $35^{\circ} \mathrm{C}$ for $24 \mathrm{~h}$. Salmonella strains were streaked on Xylose Lysine Deoxycholate Agar (XLD, Neogen, Lansing, MI), while Modified Oxford Agar (MOX, Difco, Sparks, MD) was used for Listeria monocytogenes and MacConkey Agar with Sorbitol (SMAC, Neogen, Lansing, MI) was used for E. coli O157:H7. Isolated colonies were used for inoculum preparation.

\subsubsection{Preparation of Inocula}

Each strain was individually transferred into $10 \mathrm{ml}$ of Tryptic Soy Broth (TSB, Neogen, Lansing, MI) and grown at $35^{\circ} \mathrm{C}$ for $18 \mathrm{~h}$. After incubation, equal volumes of each strain were pooled within a species to form a cocktail. Each cocktail was centrifuged (1,800 $\mathrm{g} \times 15 \mathrm{~min})$, washed twice with $0.1 \%$ peptone water and resuspended in $0.1 \%$ peptone water. Direct microscope count (DMC) was done with a Petroff-Hausser Counting Chamber (Hausser Scientific, Horsham, PA) to determine the initial stock concentration. Cocktails were diluted 
to the target concentration using $0.1 \%$ peptone water. Initial counts were confirmed by plating on Tryptic Soy Agar (TSA, Neogen, Lansing, MI) and incubating at $35^{\circ} \mathrm{C}$ for $24 \mathrm{~h}$.

\subsubsection{Antimicrobials and Sodium Replacement Agents}

Antimicrobial SEA-i F75 was received from Bienca and stored refrigerated until use. SEA-i F75 was used at a concentration of $0.25 \%$ in all treatments. Three sodium replacement agents received from several suppliers were also used in the study; Alta 2345, potassium chloride, and Salona were used a concentrations of $0.25 \%, 1.0 \%$ and $0.95 \%$, respectively. Sodium replacement agents were stored at ambient temperature until use.

\subsubsection{Product Formulations and Preparation}

Six formulations of low-moisture part-skim mozzarella cheese were produced at the Dairy Products Technology Center and used in the study (Table 7.3). An antimicrobial dip was produced using sterile DI water and SEA-i F75 at a concentration of $0.25 \%$. Prior to inoculation, four of the cheese formulations, low sodium treated, $\mathrm{NaCl} / \mathrm{KCl}$ combination, $\mathrm{NaCl} /$ Alta 2345 combination and $\mathrm{NaCl} /$ Salona combination, were dipped in the antimicrobial solution for two minutes. After dipping, cheese pieces were allowed to dry for thirty minutes in a biosafety cabinet before inoculation. Regular sodium and low sodium untreated cheeses served as positive controls. 
Table 7.1 Formulations of low-moisture part-skim mozzarella cheese used in the final cheese challenge study.

\begin{tabular}{lcc}
\hline Formulation & Salt $(\mathrm{NaCl})$ Content & Dipped in Antimicrobial $(\mathrm{Y} / \mathrm{N})$ \\
\hline & & \\
Regular Sodium & $1.7 \%$ & No \\
Low Sodium Untreated & $0.7 \%$ & No \\
Low Sodium Treated & $0.7 \%$ & Yes \\
NaCl/KCl Combination & $0.7 \%$ & Yes \\
NaCl/Alta 2345 Combination & $0.7 \%$ & Yes \\
NaCl/Salona Combination & $0.7 \%$ & Yes
\end{tabular}

\subsubsection{Product Inoculation and Incubation}

Fifteen gram pieces of cheese from each formulation were inoculated with $30 \mu \mathrm{l}$ of Salmonella, Listeria monocytogenes or E. coli $0157: \mathrm{H} 7$ cocktails at a target concentration of $10^{2}-10^{3} \mathrm{CFU} / \mathrm{g}$. Uninoculated product served as a negative control. The cocktail was allowed to dry for one hour then product was transferred to bags, vacuum-sealed and incubated at $4^{\circ}$ or $12^{\circ} \mathrm{C}$. Samples incubated at $4^{\circ} \mathrm{C}$ were tested after $0,1,7,15$ and 35 days of incubation, while samples incubated at $12^{\circ} \mathrm{C}$ were tested after $0,1,3,7,14$, and 35 days of incubation. The experiment was repeated three times.

\subsubsection{Sample Pulls and Enumeration}

At each pull time, three inoculated samples and two uninonculated samples of each formulation were pulled from the incubator and diluted with $0.1 \%$ peptone water. Inoculated samples were tested for either $L$. monocytogenes, Salmonella or E. coli O157:H7. Uninoculated samples were tested, in duplicate, for coliforms, yeast, mold, psychrotrophs, $\mathrm{pH}$ and water 
activity. Samples were enumerated, in duplicate, on selective media and incubated for $48 \mathrm{~h}$. Xylose Lysine Deoxycholate Agar (XLD), MacConkey Agar with Sorbitol (SMAC), and Modified Oxford Agar (MOX) were used for enumeration of Salmonella, E. coli O157:H7 and L. monocytogenes, respectively. Colonies exhibiting the typical morphologies/reactions of each organism were counted as the organism. No other confirmations were performed.

\subsection{Results}

There were major flaws in the execution of this study. In the first experimental trial, expired SEA-i F75 was used in the treated samples. Additional efficacy screenings in TSA and milk agar showed that the antimicrobial activity of the enzyme had not reduced after expiration. However, the validity of results obtained through the use of expired enzyme is questionable. Results from second and third experimental trials were combined. Though unexpired SEA-i F75 was used in the second and third experimental trials, cheeses used in both trials had high counts of spoilage microorganisms.

\subsubsection{Preliminary Analysis}

Water activity and $\mathrm{pH}$ values of the six formulations over all trials were combined and averaged. Initial $\mathrm{pH}$ values were similar across all six formulations, ranging from 5.39-5.52. During incubation, $\mathrm{pH}$ values increased in samples incubated at $4^{\circ} \mathrm{C}$ and decreased in samples incubated at $12^{\circ} \mathrm{C}$ for all formulations. Water activity values were also similar across all formulations. 
However, the water activity of regular sodium cheese was slightly lower than that of the low sodium formulations. Initial water activity in regular sodium cheeses averaged 0.9823 while water activity values for low sodium cheeses ranged from $0.9908-0.9953$. 
Table 7.2 Average pH and water activity values for uninoculated samples of six formulations of low-moisture part-skim (LMPS) mozzarella cheese after incubation at $4^{\circ}$ and $12^{\circ} \mathrm{C}$.

\begin{tabular}{|c|c|c|c|c|c|c|c|c|c|c|c|c|}
\hline \multirow{3}{*}{ Pull Date } & \multicolumn{12}{|c|}{ Cheese Formulation } \\
\hline & \multicolumn{2}{|c|}{ Regular Sodium } & \multicolumn{2}{|c|}{ Low Sodium Untreated } & \multicolumn{2}{|c|}{ Low Sodium Treated } & \multicolumn{2}{|c|}{$\mathrm{NaCl} / \mathrm{KCl}$ Combination } & \multicolumn{2}{|c|}{$\mathrm{NaCl} /$ Alta Combination } & \multicolumn{2}{|c|}{$\begin{array}{l}\mathrm{NaCl} / \text { Salona } \\
\text { Combination }\end{array}$} \\
\hline & $4^{\circ} \mathrm{C}$ & $12^{\circ} \mathrm{C}$ & $4^{\circ} \mathrm{C}$ & $12^{\circ} \mathrm{C}$ & $4^{\circ} \mathrm{C}$ & $12^{\circ} \mathrm{C}$ & $4^{\circ} \mathrm{C}$ & $12^{\circ} \mathrm{C}$ & $4^{\circ} \mathrm{C}$ & $12^{\circ} \mathrm{C}$ & $4^{\circ} \mathrm{C}$ & $12^{\circ} \mathrm{C}$ \\
\hline \multicolumn{13}{|l|}{ Day 0} \\
\hline $\mathrm{pH} \pm S D$ & $5.52 \pm 0.08$ & $5.52 \pm 0.08$ & $5.42 \pm 0.17$ & $5.42 \pm 0.17$ & $5.46 \pm 0.26$ & $5.46 \pm 0.26$ & $5.48 \pm 0.13$ & $5.48 \pm 0.13$ & $5.39 \pm 0.22$ & $5.39 \pm 0.22$ & $5.43 \pm 0.19$ & $5.43 \pm 0.19$ \\
\hline$a_{w}$ & 0.9823 & 0.9823 & 0.9908 & 0.9908 & 0.9913 & 0.9913 & 0.9902 & 0.9902 & 0.9953 & 0.9953 & 0.9934 & 0.9934 \\
\hline \multicolumn{13}{|l|}{ Day 1} \\
\hline $\mathrm{pH} \pm \mathrm{SD}$ & $5.58 \pm 0.14$ & $5.44 \pm 0.18$ & $5.63 \pm 0.16$ & $5.56 \pm 0.10$ & $5.65 \pm 0.21$ & $5.61 \pm 0.09$ & $5.61 \pm 0.18$ & $5.44 \pm 0.19$ & $5.46 \pm 0.50$ & $5.48 \pm 0.34$ & $5.53 \pm 0.24$ & $5.38 \pm 0.38$ \\
\hline$a_{w}$ & 0.9827 & 0.9815 & 0.9897 & 0.9919 & 0.9919 & 0.9903 & 0.9907 & 0.9903 & 0.9931 & 0.9926 & 0.9924 & 0.9901 \\
\hline \multicolumn{13}{|l|}{ Day 3} \\
\hline $\mathrm{pH} \pm \mathrm{SD}$ & NT & $5.34 \pm 0.29$ & NT & $5.34 \pm 0.32$ & NT & $5.45 \pm 0.37$ & NT & $5.40 \pm 0.34$ & NT & $5.43 \pm 0.42$ & NT & $5.40 \pm 0.30$ \\
\hline$a_{w}$ & NT & 0.9824 & NT & 0.9909 & NT & 0.9930 & NT & 0.9912 & NT & 0.9943 & NT & 0.9926 \\
\hline \multicolumn{13}{|l|}{ Day 7} \\
\hline $\mathrm{pH} \pm \mathrm{SD}$ & $5.57 \pm 0.35$ & $5.31 \pm 0.32$ & $5.69 \pm 0.34$ & $5.23 \pm 0.45$ & $5.65 \pm 0.38$ & $5.27 \pm 0.52$ & $5.75 \pm 0.26$ & $5.22 \pm 0.44$ & $5.49 \pm 0.54$ & $5.08 \pm 0.42$ & $5.57 \pm 0.42$ & $5.18 \pm 0.47$ \\
\hline$a_{w}$ & 0.9830 & 0.9830 & 0.9919 & 0.9896 & 0.9925 & 0.9908 & 0.9918 & 0.9901 & 0.9942 & 0.9931 & 0.9933 & 0.9912 \\
\hline \multicolumn{13}{|l|}{ Day 15} \\
\hline $\mathrm{pH} \pm \mathrm{SD}$ & $5.70 \pm 0.13$ & $5.02 \pm 0.32$ & $5.67 \pm 0.31$ & $5.08 \pm 0.39$ & $5.72 \pm 0.28$ & $5.13 \pm 0.33$ & $5.65 \pm 0.38$ & $5.01 \pm 0.24$ & $5.55 \pm 0.48$ & $4.84 \pm 0.17$ & $5.65 \pm 0.30$ & $4.92 \pm 0.27$ \\
\hline$a_{w}$ & 0.9840 & 0.9790 & 0.9908 & 0.9869 & 0.9924 & 0.9882 & 0.9912 & 0.9881 & 0.9930 & 0.9903 & 0.9915 & 0.9889 \\
\hline \multicolumn{13}{|l|}{ Day 35} \\
\hline $\mathrm{pH} \pm \mathrm{SD}$ & $6.43 \pm 0.04$ & $4.93 \pm 0.01$ & $6.39 \pm 0.03$ & $5.07 \pm 0.07$ & $6.46 \pm 0.13$ & $5.21 \pm 0.28$ & $6.78 \pm 0.11$ & $4.93 \pm 0.02$ & $6.80 \pm 0.02$ & $5.43 \pm 0.13$ & $6.47 \pm 0.02$ & $5.03 \pm 0.19$ \\
\hline$a_{w}$ & 0.9829 & 0.9803 & 0.9904 & 0.9881 & 0.9897 & 0.9883 & 0.9909 & 0.9873 & 0.9933 & 0.9905 & 0.9927 & 0.9880 \\
\hline
\end{tabular}


Table 7.3 Average coliform, yeast, mold and psychrotroph counts (log CFU/g) for uninoculated samples of six formulations of low-moisture part-skim (LMPS) mozzarella cheese after incubation at $4^{\circ}$ and $12^{\circ} \mathrm{C}$ (Trial 1).

\begin{tabular}{|c|c|c|c|c|c|c|c|c|c|c|c|c|}
\hline \multirow{2}{*}{ Pull Date } & \multicolumn{2}{|c|}{ Regular Sodium } & \multicolumn{2}{|c|}{ Low Sodium Untreated } & \multicolumn{2}{|c|}{ Low Sodium Treated } & \multicolumn{2}{|c|}{$\mathrm{NaCl} / \mathrm{KCl}$ Combination } & \multicolumn{2}{|c|}{$\mathrm{NaCl} /$ Alta Combination } & \multicolumn{2}{|c|}{$\mathrm{NaCl} /$ Salona Combination } \\
\hline & $4^{\circ} \mathrm{C}$ & $12^{\circ} \mathrm{C}$ & $4^{\circ} \mathrm{C}$ & $12^{\circ} \mathrm{C}$ & $4^{\circ} \mathrm{C}$ & $12^{\circ} \mathrm{C}$ & $4^{\circ} \mathrm{C}$ & $12^{\circ} \mathrm{C}$ & $4^{\circ} \mathrm{C}$ & $12^{\circ} \mathrm{C}$ & $4^{\circ} \mathrm{C}$ & $12^{\circ} \mathrm{C}$ \\
\hline \multicolumn{13}{|l|}{ Day 0} \\
\hline Coliforms & 1.65 & 1.65 & 3.93 & 3.93 & $<1$ & $<1$ & 2.53 & 2.53 & $<1$ & $<1$ & $<1$ & $<1$ \\
\hline Yeast & 1.24 & 1.24 & 1.81 & 1.81 & $<1$ & $<1$ & 1.48 & 1.48 & 1.51 & 1.51 & $<1$ & $<1$ \\
\hline Mold & $<1$ & $<1$ & $<1$ & $<1$ & $<1$ & $<1$ & $<1$ & $<1$ & $<1$ & $<1$ & $<1$ & $<1$ \\
\hline $\begin{array}{l}\text { Psychrotrophs } \\
\text { Day } 1\end{array}$ & 3.60 & 3.60 & 4.22 & 4.22 & 1.76 & 1.76 & 4.10 & 4.10 & 4.60 & 4.60 & 3.03 & 3.03 \\
\hline Coliforms & 2.22 & $<1$ & $<1$ & 1.51 & $<1$ & 0.70 & 0.40 & 2.73 & 3.98 & 3.58 & $<1$ & 2.07 \\
\hline Yeast & 2.32 & $<1$ & $<1$ & 0.70 & $<1$ & 0.40 & 1.18 & 3.32 & $<1$ & $<1$ & $<1$ & $<1$ \\
\hline Mold & $<1$ & $<1$ & $<1$ & $<1$ & $<1$ & $<1$ & $<1$ & $<1$ & $<1$ & $<1$ & $<1$ & $<1$ \\
\hline $\begin{array}{l}\text { Psychrotrophs } \\
\text { Day } 3\end{array}$ & 4.36 & 2.91 & 0.70 & 4.48 & 1.97 & 3.04 & 2.87 & 4.57 & $<1$ & $<1$ & $<1$ & $<1$ \\
\hline Coliforms & NT & 2.95 & NT & 2.50 & NT & 1.63 & NT & 2.93 & NT & 2.84 & NT & $<1$ \\
\hline Yeast & NT & $<1$ & NT & $<1$ & NT & $<1$ & NT & $<1$ & NT & 1.83 & NT & 1.63 \\
\hline Mold & NT & $<1$ & NT & $<1$ & NT & $<1$ & NT & $<1$ & NT & $<1$ & NT & $<1$ \\
\hline $\begin{array}{l}\text { Psychrotrophs } \\
\text { Day } 7\end{array}$ & NT & 4.61 & NT & 3.09 & NT & 4.55 & NT & 4.40 & 2.94 & 2.94 & NT & 4.47 \\
\hline Coliforms & 0.40 & 3.03 & 0.70 & 0.70 & 1.86 & 3.37 & $<1$ & $<1$ & 1.65 & $<1$ & $<1$ & 1.92 \\
\hline Yeast & $<1$ & $<1$ & $<1$ & $<1$ & $<1$ & 1.35 & $<1$ & $<1$ & 2.69 & 3.26 & 2.41 & $<1$ \\
\hline Mold & $<1$ & 1.88 & $<1$ & $<1$ & $<1$ & $<1$ & 1.24 & $<1$ & $<1$ & $<1$ & $<1$ & $<1$ \\
\hline $\begin{array}{l}\text { Psychrotrophs } \\
\text { Day } 15\end{array}$ & 4.34 & 4.20 & 2.36 & 2.47 & 3.46 & 4.34 & 3.95 & 3.26 & 2.59 & 3.01 & 2.78 & 2.95 \\
\hline Coliforms & 3.17 & 3.78 & 0.88 & 2.68 & 2.33 & 2.35 & 2.74 & 2.70 & 2.82 & 3.43 & 2.73 & 1.57 \\
\hline Yeast & $<1$ & 0.88 & $<1$ & $<1$ & $<1$ & $<1$ & $<1$ & 1.24 & $<1$ & $<1$ & $<1$ & $<1$ \\
\hline Mold & $<1$ & 2.04 & $<1$ & $<1$ & $<1$ & $<1$ & $<1$ & $<1$ & $<1$ & $<1$ & $<1$ & $<1$ \\
\hline $\begin{array}{l}\text { Psychrotrophs } \\
\text { Day } 35\end{array}$ & 3.96 & 3.74 & 2.38 & 2.35 & 3.84 & 4.30 & 4.85 & 4.21 & 4.34 & 4.81 & 4.56 & 4.79 \\
\hline Coliforms & 5.65 & 5.33 & 0.70 & 5.65 & 5.46 & 2.97 & 4.32 & 4.27 & 5.14 & 5.94 & 3.99 & 5.53 \\
\hline Yeast & $<1$ & 2.51 & $<1$ & $<1$ & $<1$ & $<1$ & $<1$ & 1.48 & $<1$ & $<1$ & $<1$ & $<1$ \\
\hline Mold & 1.92 & 2.11 & 1.80 & $<1$ & 2.76 & 0.40 & $<1$ & 1.00 & 3.26 & $<1$ & $<1$ & $<1$ \\
\hline Psychrotrophs & 5.17 & 5.37 & 3.22 & $<1$ & 4.20 & 4.14 & 5.80 & 5.08 & 6.10 & 6.22 & 5.89 & 6.39 \\
\hline
\end{tabular}


Table 7.4 Average coliform, yeast, mold and psychrotroph counts (log CFU/g) for uninoculated samples of six formulations of low-moisture part-skim (LMPS) mozzarella cheese after incubation at $4^{\circ}$ and $12^{\circ} \mathrm{C}$ (Trials 2 and 3 ).

\begin{tabular}{|c|c|c|c|c|c|c|c|c|c|c|c|c|}
\hline \multirow[t]{2}{*}{ Pull Date } & \multicolumn{2}{|c|}{ Regular Sodium } & \multicolumn{2}{|c|}{ Low Sodium Untreated } & \multicolumn{2}{|c|}{ Low Sodium Treated } & \multicolumn{2}{|c|}{$\mathrm{NaCl} / \mathrm{KCl}$ Combination } & \multicolumn{2}{|c|}{ NaCl/Alta Combination } & \multicolumn{2}{|c|}{$\begin{array}{l}\mathrm{NaCl} / \text { Salona } \\
\text { Combination }\end{array}$} \\
\hline & $4^{\circ} \mathrm{C}$ & $12^{\circ} \mathrm{C}$ & $4^{\circ} \mathrm{C}$ & $12^{\circ} \mathrm{C}$ & $4^{\circ} \mathrm{C}$ & $12^{\circ} \mathrm{C}$ & $4^{\circ} \mathrm{C}$ & $12^{\circ} \mathrm{C}$ & $4^{\circ} \mathrm{C}$ & $12^{\circ} \mathrm{C}$ & $4^{\circ} \mathrm{C}$ & $12^{\circ} \mathrm{C}$ \\
\hline \multicolumn{13}{|l|}{ Day 0} \\
\hline Coliforms & 5.72 & 5.72 & 5.89 & 5.89 & 5.15 & 5.15 & 4.12 & 4.12 & 4.91 & 4.91 & 4.22 & 4.22 \\
\hline Yeast & 1.33 & 1.53 & 3.96 & 3.96 & 1.38 & 1.38 & 2.14 & 2.14 & 2.53 & 2.53 & 1.00 & 1.00 \\
\hline Mold & 2.77 & 2.77 & 1.24 & 1.24 & 2.03 & 2.03 & 2.98 & 2.98 & 3.34 & 3.34 & 1.81 & 1.81 \\
\hline Psychrotrophs & 4.74 & 4.74 & 4.64 & 4.64 & 4.87 & 4.87 & 5.02 & 5.02 & 4.13 & 4.13 & 4.30 & 4.30 \\
\hline \multicolumn{13}{|l|}{ Day 1} \\
\hline Coliforms & 4.49 & 4.94 & 4.73 & 5.31 & 4.38 & 4.27 & 4.00 & 4.22 & 3.99 & 4.13 & 3.64 & 4.09 \\
\hline Yeast & $<1$ & 2.73 & 2076 & 2.40 & 2.81 & 3.39 & 0.70 & 2.95 & 3.77 & 3.13 & 2.26 & 3.40 \\
\hline Mold & 2.54 & 2.90 & 2.49 & 2.33 & 1.21 & 0.40 & 2.58 & 3.15 & 2.97 & 3.38 & 3.11 & 3.34 \\
\hline Psychrotrophs & 5.37 & 5.31 & 5.46 & 5.23 & 5.61 & 4.81 & 4.86 & 4.64 & 4.61 & 4.23 & 4.85 & 4.50 \\
\hline \multicolumn{13}{|l|}{ Day 3} \\
\hline Coliforms & NT & 5.36 & NT & 5.58 & NT & 5.50 & NT & 4.94 & NT & 4.06 & NT & 4.43 \\
\hline Yeast & NT & 1.10 & NT & 1.35 & NT & 1.74 & NT & 0.88 & NT & 1.00 & NT & 2.19 \\
\hline Mold & NT & 2.98 & NT & 1.71 & NT & 2.80 & NT & 3.28 & NT & 3.49 & NT & 3.38 \\
\hline Psychrotrophs & NT & 5.55 & NT & 5.35 & NT & 5.66 & NT & 3.53 & NT & 3.96 & NT & 4.17 \\
\hline \multicolumn{13}{|l|}{ Day 7} \\
\hline Coliforms & 4.60 & 5.40 & 4.83 & 5.40 & 4.57 & 5.13 & 4.12 & 4.94 & 3.7 & 4.59 & 3.90 & 4.12 \\
\hline Yeast & 3.34 & 2.98 & 2.60 & 3.08 & 2.15 & 2.60 & 3.35 & 3.03 & 2.13 & 1.14 & 2.56 & 2.99 \\
\hline Mold & 3.17 & 3.42 & 2.74 & 2.12 & 1.56 & 3.16 & 3.34 & 3.27 & 3.44 & 3.62 & 3.25 & 3.46 \\
\hline Psychrotrophs & 4.82 & 4.41 & 4.21 & 4.62 & 4.89 & 3.99 & 4.83 & 4.05 & 4.84 & 5.16 & 4.59 & 4.60 \\
\hline \multicolumn{13}{|l|}{ Day 15} \\
\hline Coliforms & 4.50 & 5.26 & 4.50 & 5.35 & 4.56 & 5.30 & 4.41 & 5.21 & 3.52 & 4.51 & 3.52 & 4.60 \\
\hline Yeast & 4.31 & 4.35 & 3.66 & 4.01 & 3.66 & 3.83 & 4.39 & 4.11 & 4.07 & 4.61 & 3.71 & 4.45 \\
\hline Mold & 3.30 & 3.37 & 3.06 & 3.12 & 2.11 & 2.91 & 3.24 & 3.35 & 3.38 & 3.63 & 3.29 & 3.43 \\
\hline Psychrotrophs & 5.70 & 3.65 & 4.79 & 3.85 & 4.70 & 4.40 & 4.97 & 4.03 & 5.21 & 4.46 & 4.88 & 3.81 \\
\hline
\end{tabular}




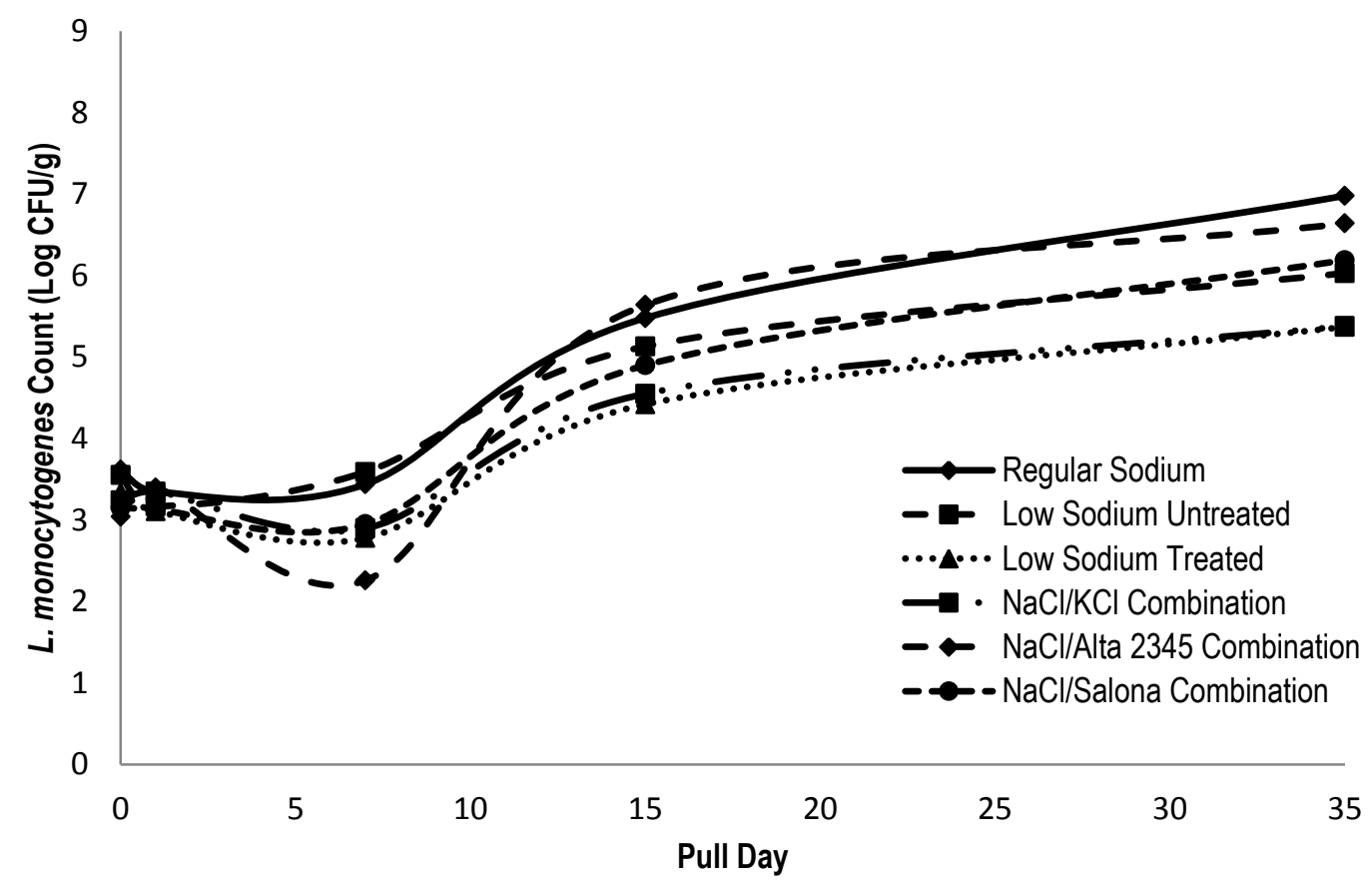

Figure 7.1 Behavior of L. monocytogenes in six formulations of low-moisture partskim (LMPS) mozzarella cheese during incubation at $4^{\circ} \mathrm{C}$ (Trial 1).

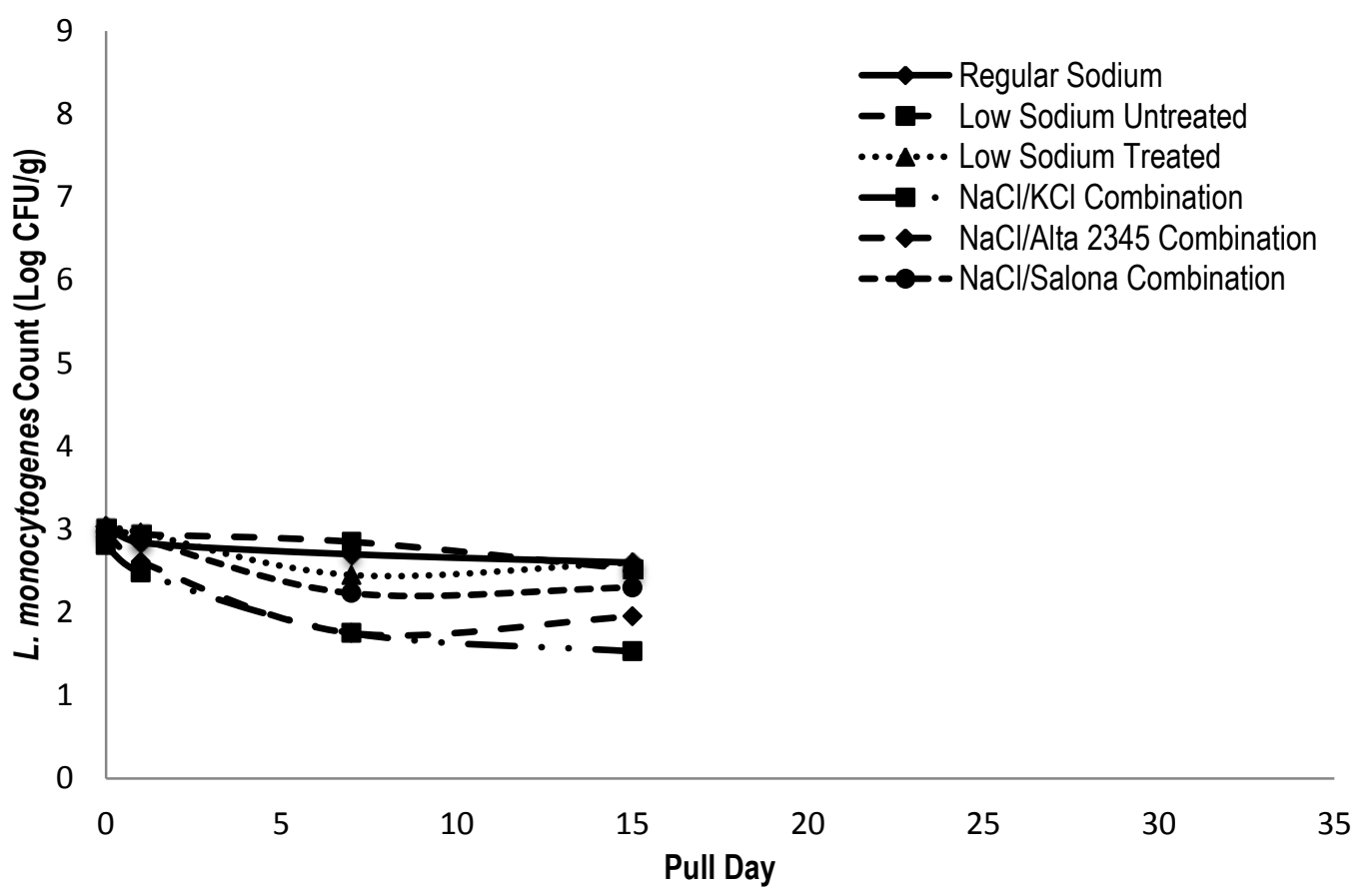

Figure 7.2 Behavior of L. monocytogenes in six formulations of low-moisture partskim (LMPS) mozzarella cheese during incubation at $4^{\circ} \mathrm{C}$ (Trials 2 and 3 ). 


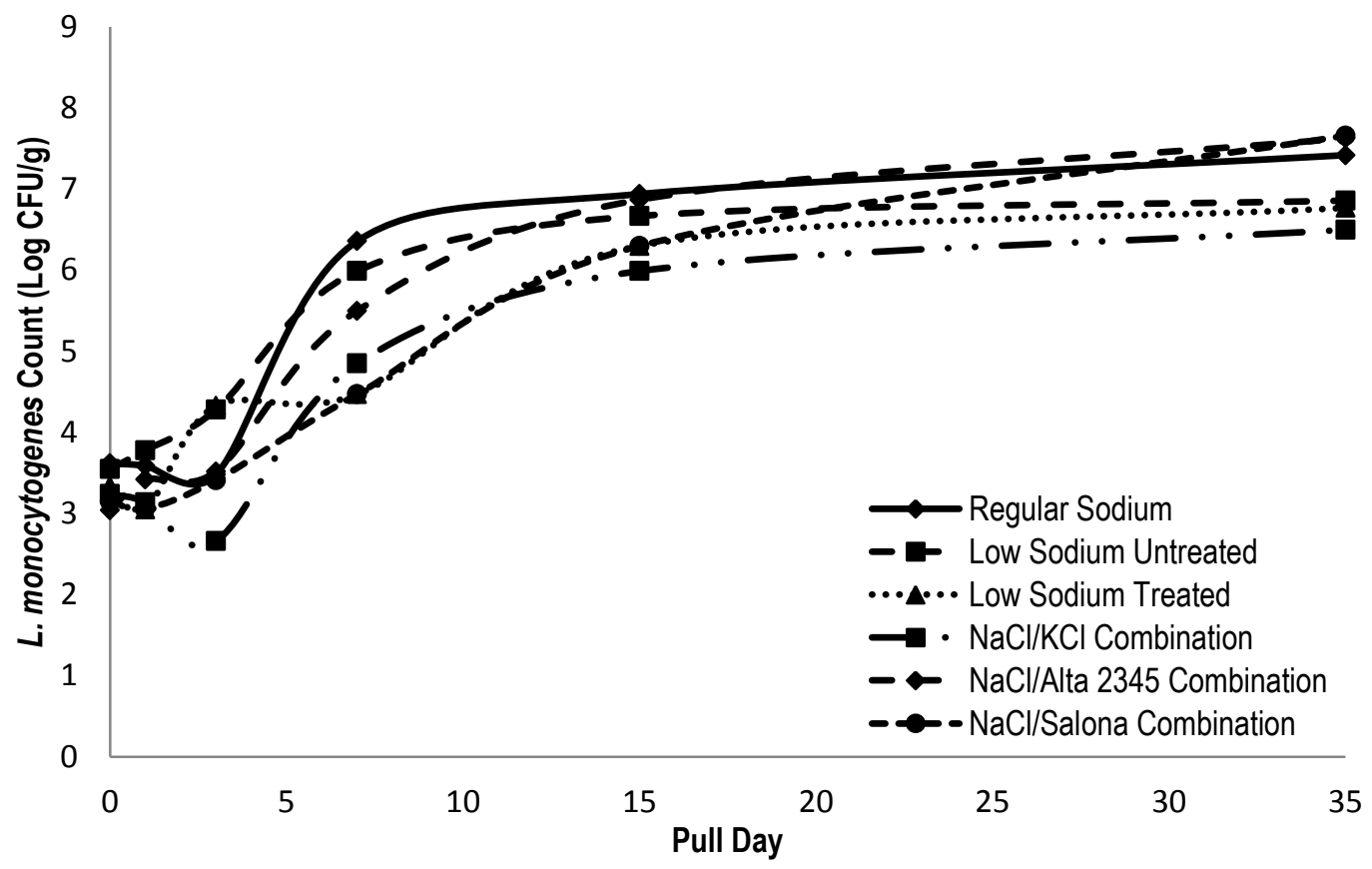

Figure 7.3 Behavior of L. monocytogenes in six formulations of low-moisture partskim (LMPS) mozzarella cheese during incubation at $12^{\circ} \mathrm{C}$ (Trial 1).

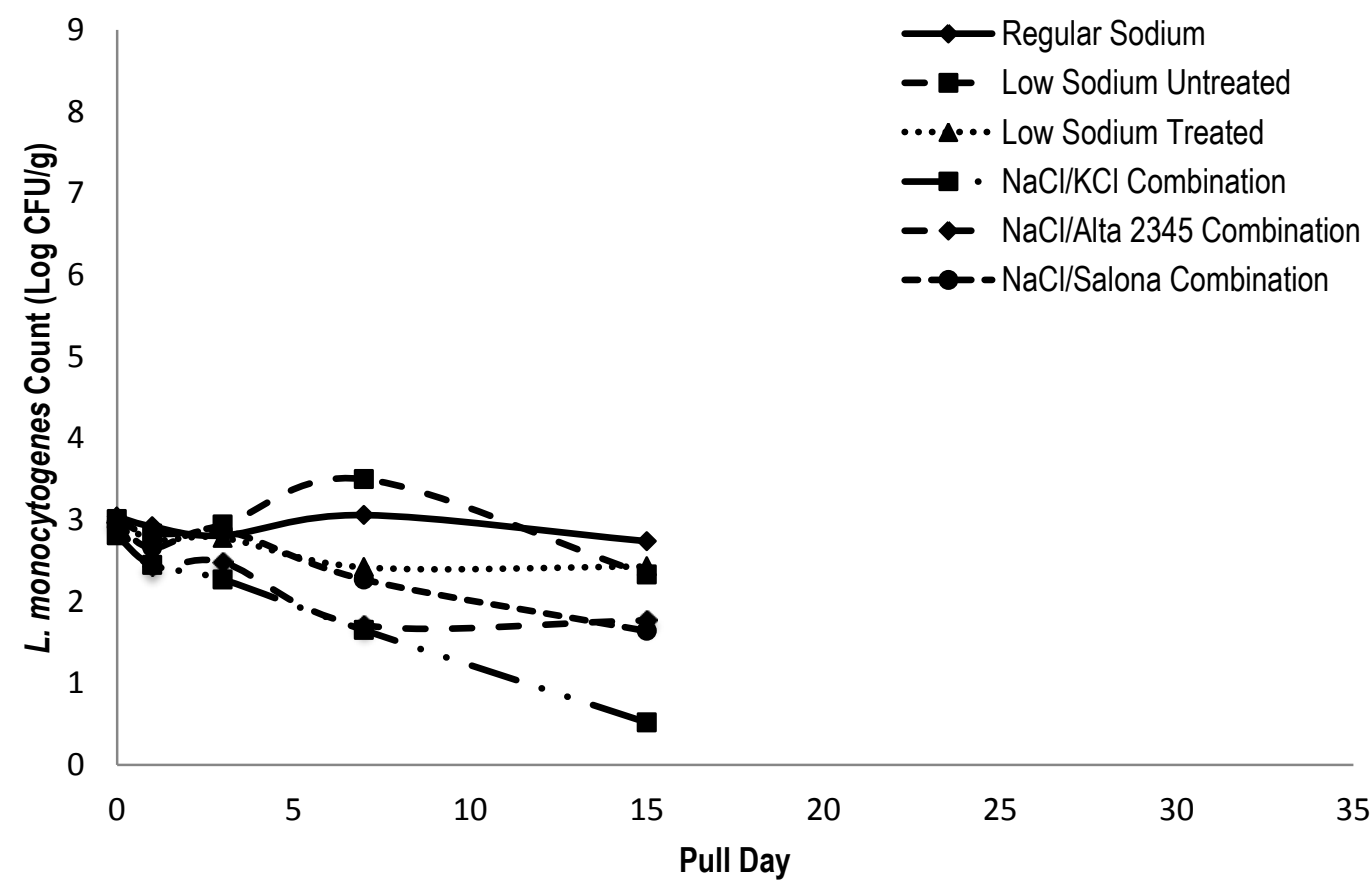

Figure 7.4 Behavior of $L$.monocytogenes in six formulations of low-moisture partskim (LMPS) mozzarella cheese during incubation at $12^{\circ} \mathrm{C}$ (Trials 2 and 3 ). 


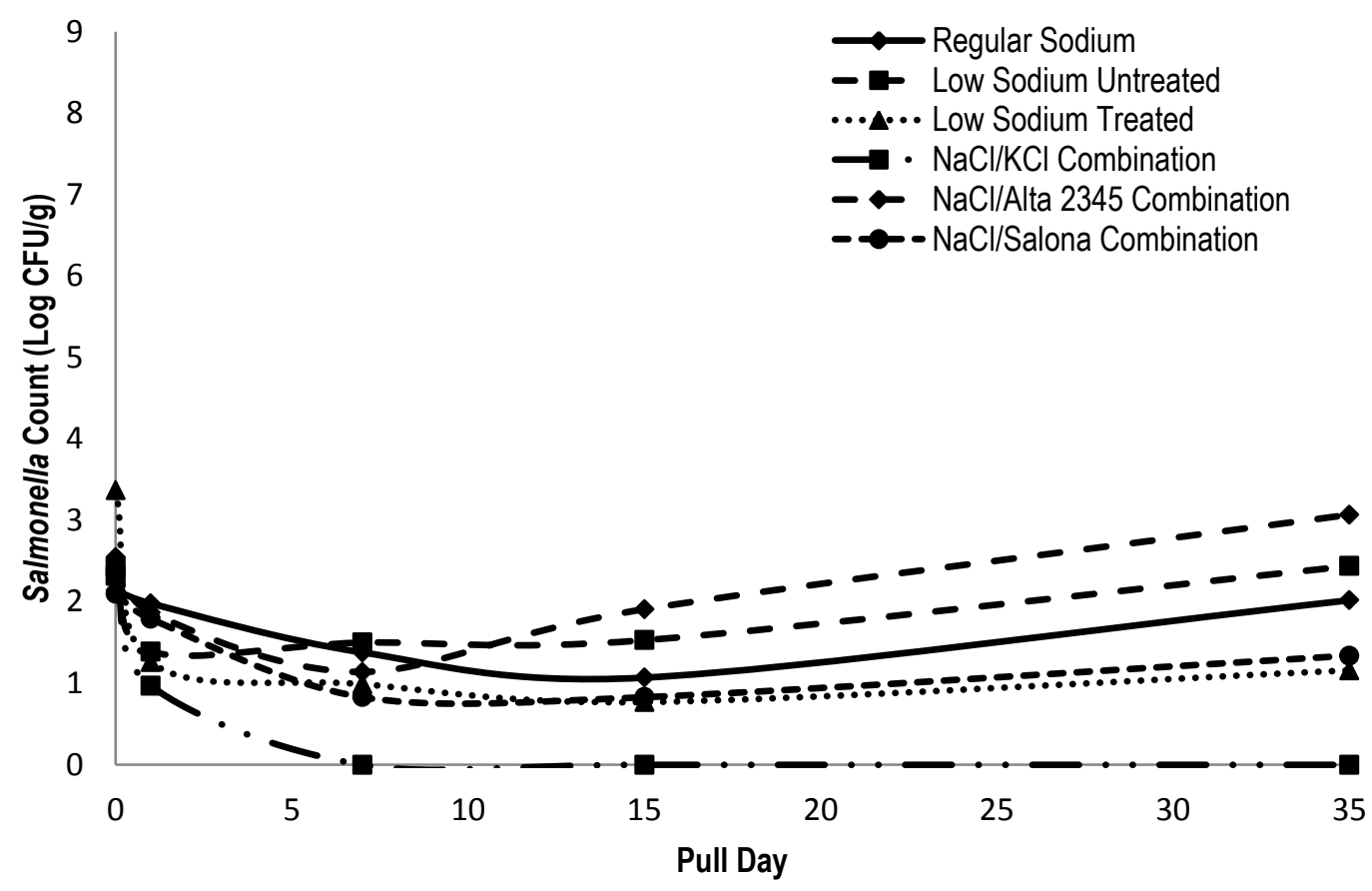

Figure 7.5 Behavior of Salmonella in six formulations of low-moisture part-skim (LMPS) mozzarella cheese during incubation at $4^{\circ} \mathrm{C}$ (Trial 1).

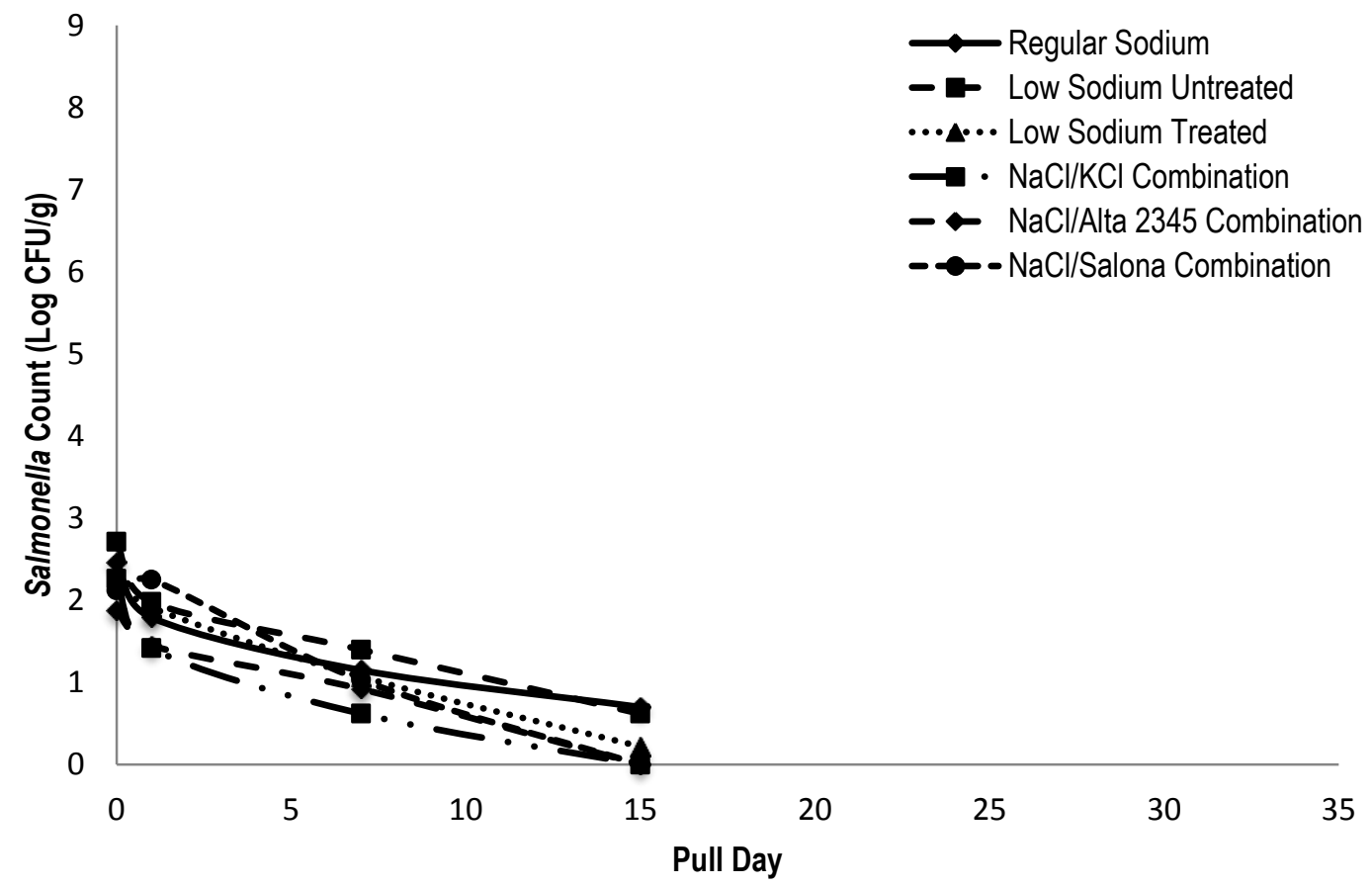

Figure 7.6 Behavior of Salmonella in six formulations of low-moisture part-skim (LMPS) mozzarella cheese during incubation at $4^{\circ} \mathrm{C}$ (Trials 2 and 3 ). 


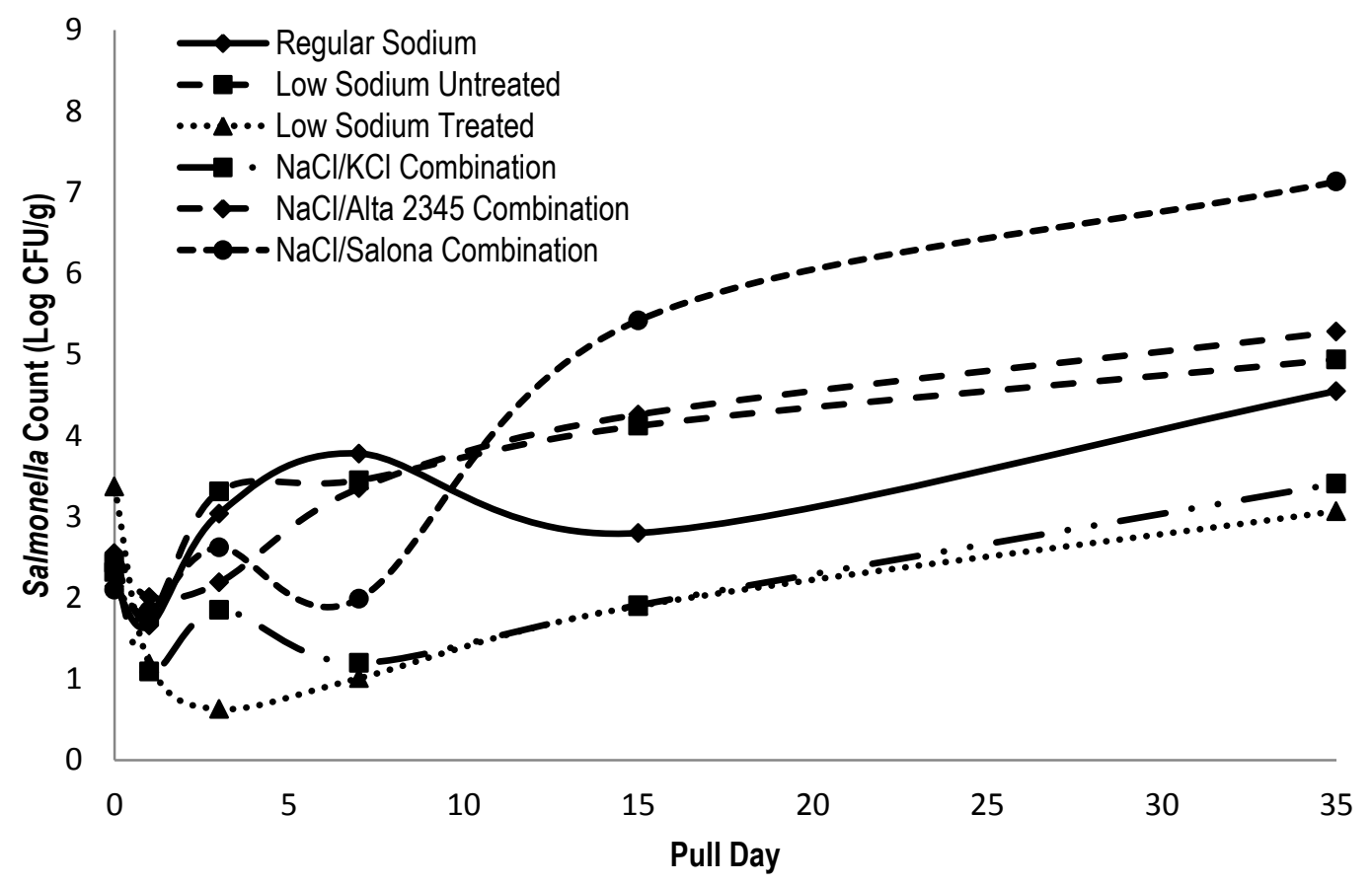

Figure 7.7 Behavior of Salmonella in six formulations of low-moisture part-skim (LMPS) mozzarella cheese during incubation at $12^{\circ} \mathrm{C}$ (Trial 1).

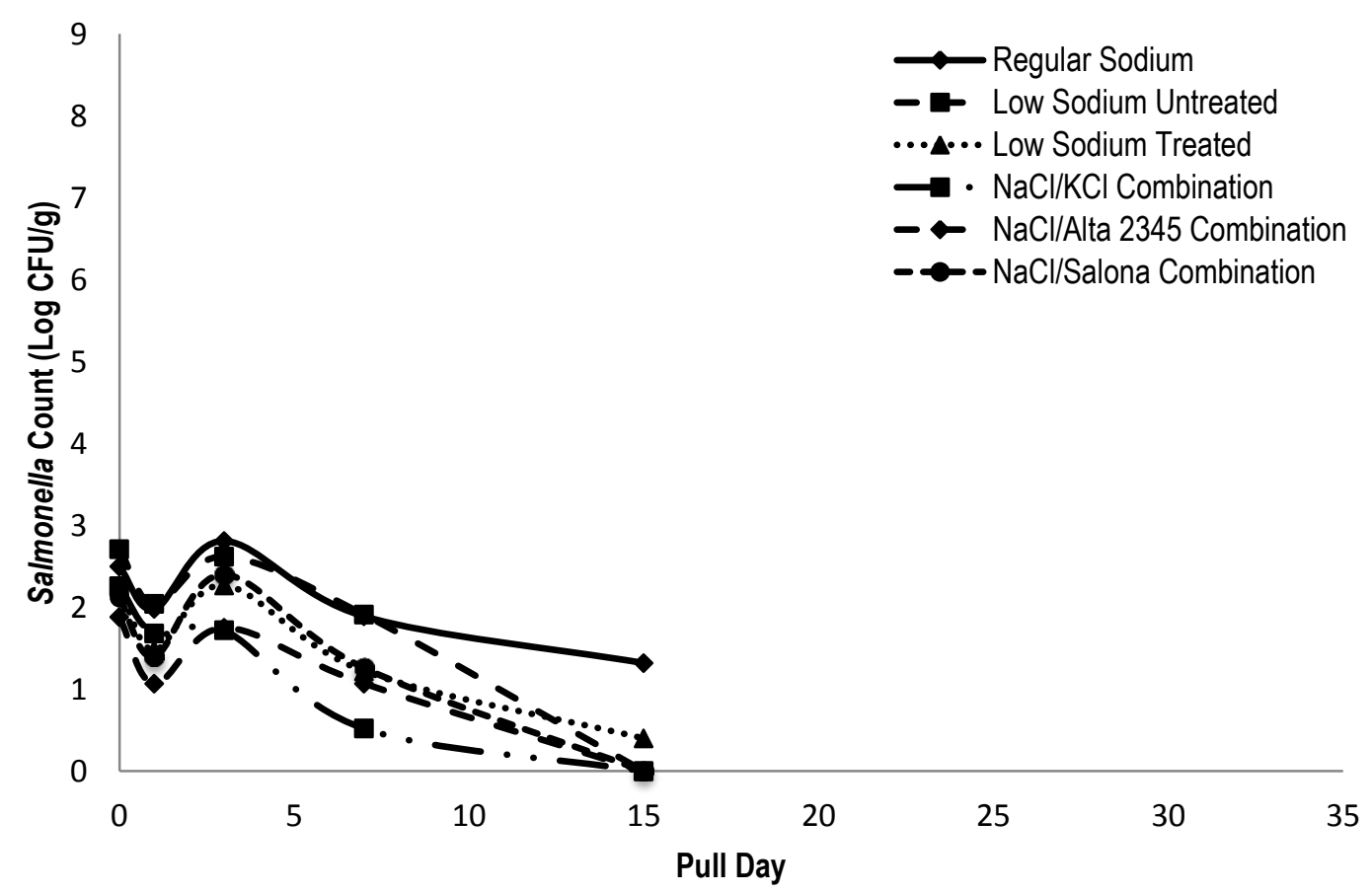

Figure 7.8 Behavior of Salmonella in six formulations of low-moisture part-skim (LMPS) mozzarella cheese during incubation at $12^{\circ} \mathrm{C}$ (Trials 2 and 3 ). 


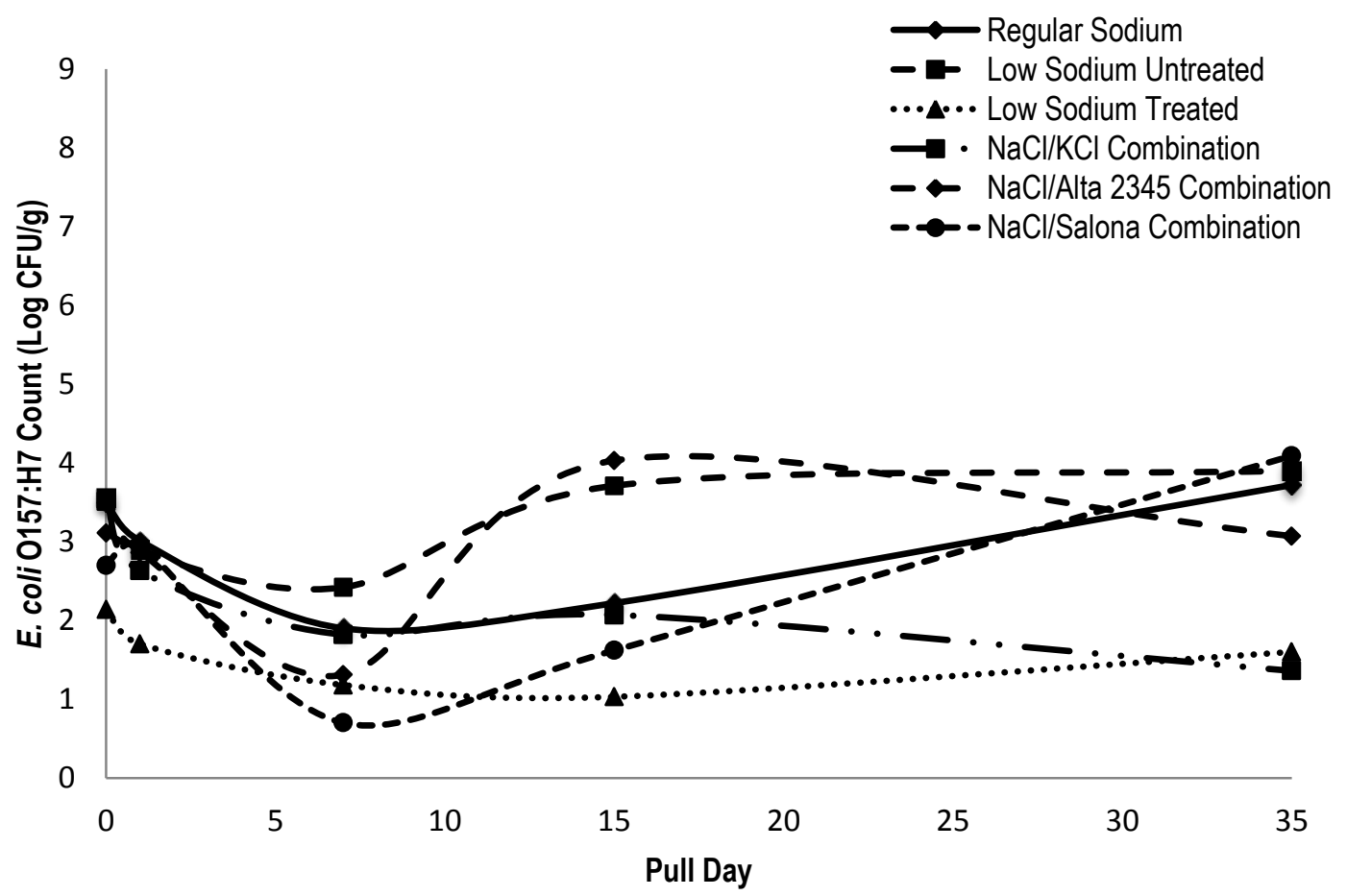

Figure 7.9 Behavior of E. coli $0157: \mathrm{H} 7$ in six formulations of low-moisture partskim (LMPS) mozzarella cheese during incubation at $4^{\circ} \mathrm{C}$ (Trial 1).

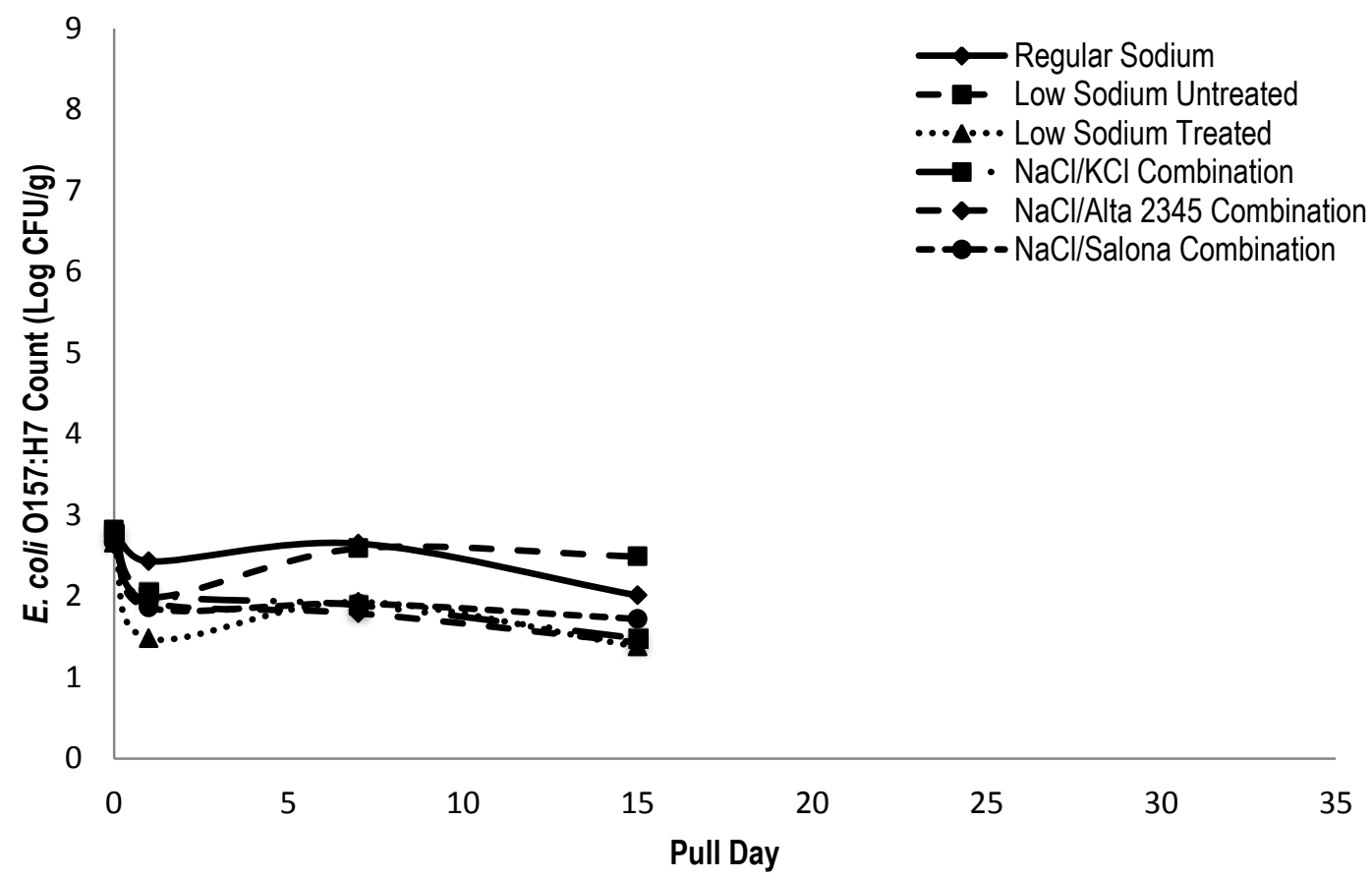

Figure 7.10 Behavior of E. coli O157:H7 in six formulations of low-moisture partskim (LMPS) mozzarella cheese during incubation at $4^{\circ} \mathrm{C}$ (Trials 2 and 3 ). 


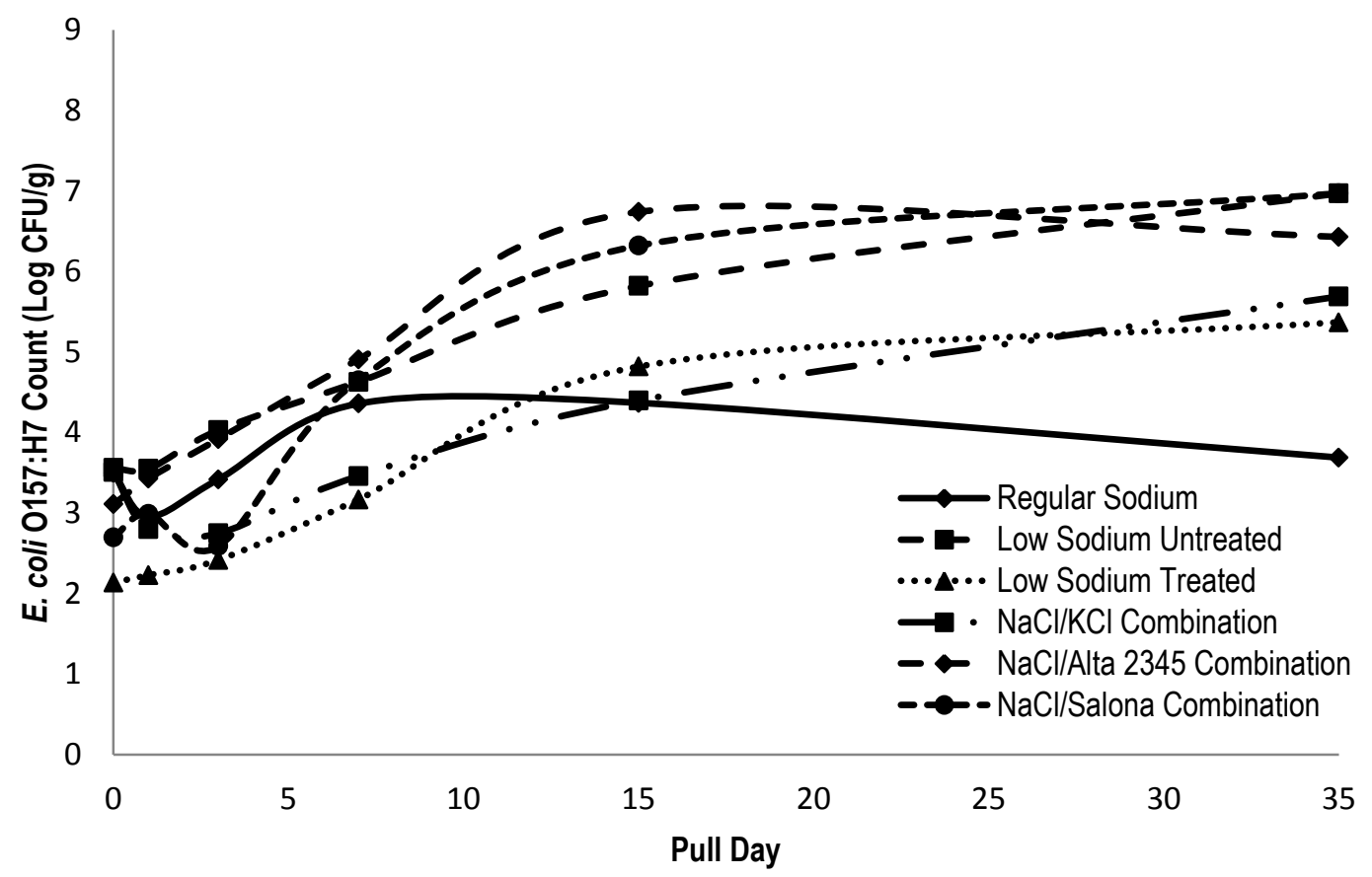

Figure 7.11 Behavior of E. coli O157:H7 in six formulations of low-moisture partskim (LMPS) mozzarella cheese during incubation at $12^{\circ} \mathrm{C}$ (Trial 1).

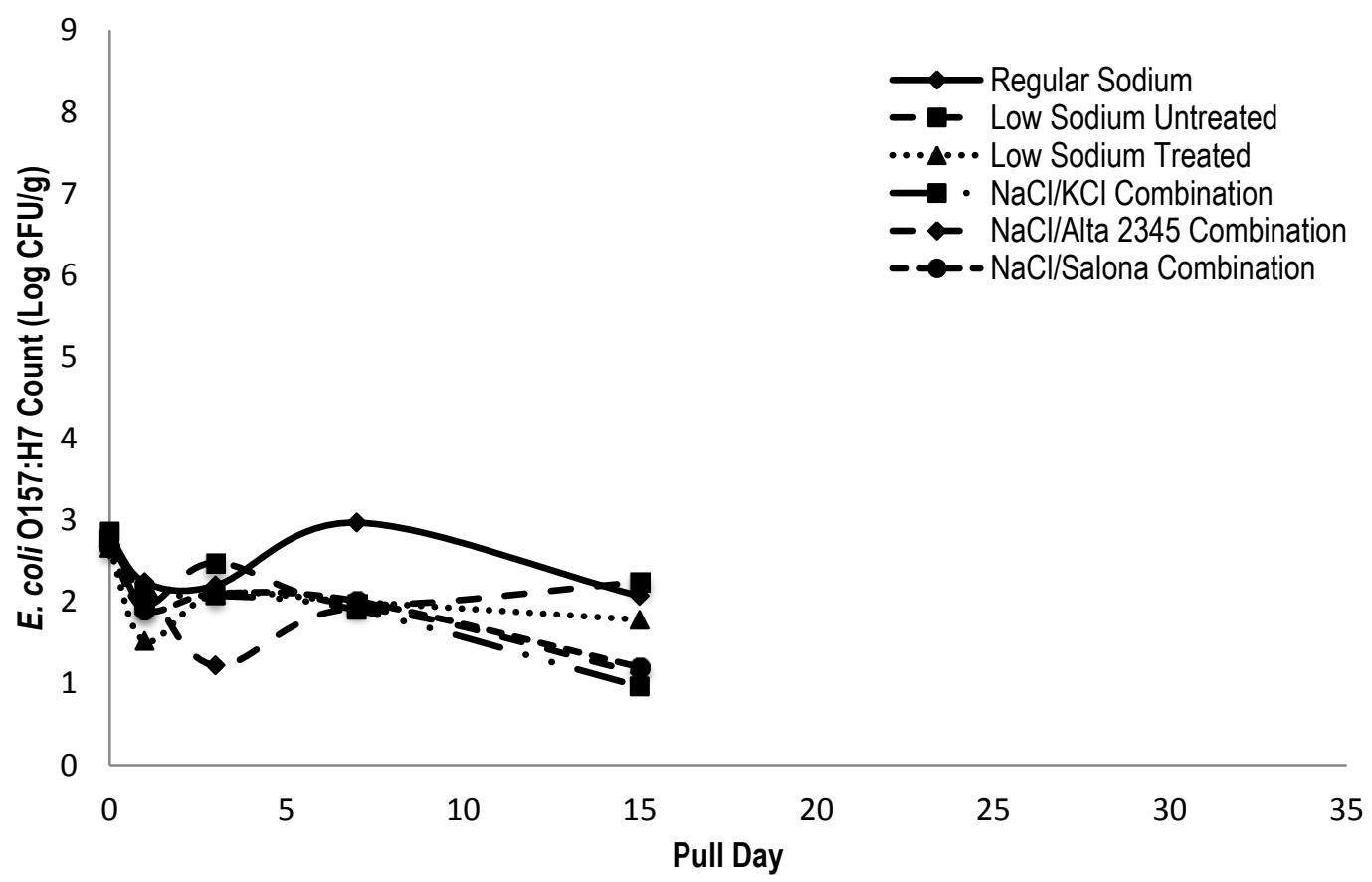

Figure 7.12 Behavior of $E$. coli $\mathrm{O} 157: \mathrm{H} 7$ in six formulations of low-moisture partskim (LMPS) mozzarella cheese during incubation at $12^{\circ} \mathrm{C}$ (Trials 2 and 3 ). 


\subsection{Discussion}

In the first experimental trial, counts of all three organisms in all formulations tested initially decreased. However, after the initial decrease Salmonella and E. coli $\mathrm{O} 157: \mathrm{H} 7$ counts recovered to the original inoculum levels after incubation at $4^{\circ} \mathrm{C}$ and increased at $12^{\circ} \mathrm{C}$, while $L$. monocytogenes counts increased at both temperatures. Salmonella and E. coli O157:H7 cannot grow at refrigeration temperatures. The decline in cellular counts followed by an increase to initial inoculum levels suggest that SEA-i F75 initially injured cells and the injured cells were unable to grow on selective media and as cells of Salmonella and $E$. coli $\mathrm{O} 157: \mathrm{H} 7$ recovered, the growth of the recovered cells was detected through plating. SEA-i F75 was not effective at inhibiting the growth of these organisms in low sodium LMPS mozzarella formulations. Previous results in cheese agar showed that chloride could potentially be contributing to the function of SEA-i F75. Therefore, low sodium LMPS mozzarella formulations could be lacking the amount of the chloride necessary to function for a prolonged period of time.

In the second experimental trials, counts of all three organisms in treated samples steadily decreased over time. However, since counts in control formulations also decreased, the reduction in counts cannot solely be attributed to the activity of SEA-i F75. While reductions in pathogens were observed, there were high background counts of coliforms and psychrotrophs in all formulations. Competition with these spoilage organisms also could have potentially contributed to the reduction in pathogenic bacteria. 


\subsection{Conclusion}

Though SEA-i F75 was the most effective antimicrobial during agar screenings, it was not effective at inhibiting the growth of Salmonella, E. coli O157:H7 and L. monocytogenes in low sodium LMPS mozzarella cheese formulations. This study aimed to identify a suitable antimicrobial for use in a low sodium LMPS mozzarella cheese system. There has been an abundance of research done on antimicrobials and sodium replacement agents in cheddar and feta cheeses, but data regarding in mozzarella is limited; this study sought to provide data that would help to fill that gap. Preliminary screening efforts yielded confidence that a lactoperoxidase-based antimicrobial would provide the best inhibition of pathogenic bacteria in low sodium LMPS mozzarella cheese. However, the results from the final study contradict that assumption.

The decrease in efficacy of SEA-i F75 in the final cheese, from preliminary results in agar systems, could be attributed to several causes. First, the poor microbial quality of the cheese used could have potentially overwhelmed the antimicrobial system. Second, the lactoperoxidase system would not have been able to function optimally if there was no halide or thiocyanate present to promote its function. Repeating the study and addressing these two issues could potentially provide different results and should be the focus of another study. Though the data from the final study does not provide much insight into which antimicrobial would work in a low sodium mozzarella system, data from preliminary screening can be used a starting point when trying to select an appropriate antimicrobial for a dairy system. Understanding the mechanisms and 
limitations of different classes of antimicrobials is a valuable tool to employ before beginning any study. 


\subsection{Future Research}

Future research includes attempting another challenge study using SEA-i

F75 with cheese of better microbial quality and/or the addition of thiocyanate to promote the function of the lactoperoxidase system. Additionally, the final cheese challenge study should be performed with one of the other three antimicrobials that showed promise in preliminary studies. Changing the food matrix could potentially increase the efficacy of these antimicrobials. 


\section{Bibliography}

ADETUNJI, V.O. and ADEGOKE, G.O. 2008. Formation of biofilm by strains of Listeria monocytogenes isolated from soft cheese 'wara' and its processing environment. African Journal of Biotechnology. 7, 2893-2897.

AGARWAL, S., MCCOY, D., GRAVES, W., GERARD, P.D. and CLARK, S. 2011. Sodium content in retail Cheddar, Mozzarella, and process cheeses varies considerably in the United States. Journal of Dairy Science. 94, 1605-1615.

ALEMDAR, S. and AGAOGLU, S. 2010. Survival of Salmonella typhimurium during the ripening of herby cheese (Otlu peynir). Journal of Food Safety. 30, 526-536.

ANDERSON, S., DEMENT, J. and BANEZ-OCFEMIA, C. 2009. Outbreak of Staphylococcus aureus Associated with the Italian Garden Restaurant.

APPEL, L.J. and ANDERSON, C.A.M. 2010. Compelling Evidence for Public Health Action to Reduce Salt Intake. New England Journal of Medicine. $362,650-652$.

ARQUES, J.L., RODRIGUEZ, E., GAYA, P., MEDINA, M., GUAMIS, B. and NUNEZ, M. 2005. Inactivation of Staphylococcus aureus in raw milk cheese by combinations of high-pressure treatments and bacteriocinproducing lactic acid bacteria. Journal of Applied Microbiology. 98, 254260.

ARQUES, J.L., RODRIGUEZ, E., NUNEZ, M. and MEDINA, M. 2008a. Antimicrobial activity of nisin, reuterin, and the lactoperoxidase system on Listeria monocytogenes and Staphylococcus aureus in cuajada, a semisolid dairy product manufactured in Spain. Journal of Dairy Science. 91, 70-75.

ARQUES, J.L., RODRIGUEZ, E., NUNEZ, M. and MEDINA, M. 2008b. Inactivation of Gram-negative pathogens in refrigerated milk by reuterin in combination with nisin or the lactoperoxidase system. European Food Research and Technology. 227, 77-82. 
ARQUES, J.L., RODRIGUEZ, E., NUNEZ, M. and MEDINA, M. 2011. Combined effect of reuterin and lactic acid bacteria bacteriocins on the inactivation of food-borne pathogens in milk. Food Control. 22, 457-461.

ASKER, D., WEISS, J. and MCCLEMENTS, D.J. 2009. Analysis of the Interactions of a Cationic Surfactant (Lauric Arginate) with an Anionic Biopolymer (Pectin): Isothermal Titration Calorimetry, Light Scattering, and Microelectrophoresis. Langmuir. 25, 116-122.

BANKAR, S.B., BULE, M.V., SINGHAL, R.S. and ANANTHANARAYAN, L. 2009. Glucose oxidase - An overview. Biotechnology Advances. 27, 489-501.

BIBBINS-DOMINGO, K., CHERTOW, G.M., COXSON, P.G., MORAN, A., LIGHTWOOD, J.M., PLETCHER, M.J. and GOLDMAN, L. 2010. Projected Effect of Dietary Salt Reductions on Future Cardiovascular Disease. New England Journal of Medicine. 362, 590-599.

BIDLAS, E. and LAMBERT, R.J.W. 2008. Comparing the antimicrobial effectiveness of $\mathrm{NaCl}$ and $\mathrm{KCl}$ with a view to salt/sodium replacement. International Journal of Food Microbiology. 124, 98-102.

BOOTS, J.W. and FLORIS, R. 2006. Lactoperoxidase: From catalytic mechanism to practical applications. International Dairy Journal. 16, 12721276.

BOZIARIS, I.S. and NYCHAS, G.J. 2006. Effect of nisin on growth boundaries of Listeria monocytogenes Scott $\mathrm{A}$, at various temperatures, $\mathrm{pH}$ and water activities. Food Microbiology. 23, 779-784.

BOZIARIS, I.S., SKANDAMIS, P.N., ANASTASIADI, M. and NYCHAS, G.J.E. 2007. Effect of $\mathrm{NaCl}$ and $\mathrm{KCl}$ on fate and growth/no growth interfaces of Listeria monocytogenes Scott $\mathrm{A}$ at different $\mathrm{pH}$ and nisin concentrations. Journal of Applied Microbiology. 102, 796-805.

BRANEN, J.K. and DAVIDSON, P.M. 2004. Enhancement of nisin, lysozyme, and monolaurin antimicrobial activities by ethylenediaminetetraacetic acid and lactoferrin. International Journal of Food Microbiology. 90, 63-74. 
BUZBY, J. 2005. Cheese Consumption Continues to Rise. Amber Waves, US Department of Agriculture Economic Research Service Vol. 3 Issue 1 (February 2005).

CDC. 1985. Epidemiologic Notes and Reports Listeriosis Outbreak Associated with Mexican-Style Cheese -- California. Morbidity and Mortality Weekly Report. 34, 357-359.

CDC. 1998. Outbreak of Escherichia coli O157:H7 Infection Associated with Eating Fresh Cheese Curds --- Wisconsin, June 1998. Morbidity and Mortality Weekly Report. 49, 911-913.

CDC. 2007. Salmonella Typhimurium Infection Associated with Raw Milk and Cheese Consumption -- Pennsylvania, 2007. Morbidity and Mortality Weekly Report. 56, 1161-1164.

CDC. 2008. Outbreak of Multi-drug Resistant Salmonella enterica serotype Newport Infections Associated with Consumption of Unpasteurized Mexican-Style Aged Cheese --- Illinois, March 2006 -- April 2007. Morbidity and Mortality Weekly Report. 57, 432-435.

CDC. 2010. Multistate Outbreak of E. coli O157:H7 Infections Associated with Cheese.

CLEVELAND, J., MONTVILLE, T.J., NES, I.F. and CHIKINDAS, M.L. 2001. Bacteriocins: safe, natural antimicrobials for food preservation. International Journal of Food Microbiology. 71, 1-20.

CODY, S.H., ABBOTT, S.L., MARFIN, A.A., SCHULZ, B., WAGNER, P., ROBBINS, K., MOHLE-BOETANI, J.C. and VUGIA, D.J. 1999. Two outbreaks of multidrug-resistant Salmonella serotype Typhimurium DT104 infections linked to raw-milk cheese in northern California. Jama-Journal of the American Medical Association. 281, 1805-1810.

D'AMICO, D.J., DRUART, M.J. and DONNELLY, C.W. 2010. Behavior of Escherichia coli O157:H7 during the Manufacture and Aging of Gouda and Stirred-Curd Cheddar Cheeses Manufactured from Raw Milk. Journal of Food Protection. 73, 2217-2224. 
DAVE, R.I., SHARMA, P., JULSON, J., MUTHUKUMARAPPAN, K. and HENNING, D.R. 2003. Effectiveness of Microgard (R) in controlling Escherichia coli $\mathrm{O} 157$ : $\mathrm{H} 7$ and Listeria monocytogenes. Journal of Food Science and Technology-Mysore. 40, 262-266.

DAVIDSON, F.M. and TAYLOR, T.M. 2007. Chemical Preservatives and Natural Antimicrobial Compounds. In: Food Microbiology: Fundamentals and Frontiers, (M.F. Doyle and L.R. Beuchat, eds.) pp. 713-745, ASM Press, Washington, D. C.

DELBES, C., ALOMAR, J., CHOUGUI, N., MARTIN, J.F. and MONTEL, M.C. 2006. Staphylococcus aureus growth and enterotoxin production during the manufacture of uncooked, semihard cheese from cows' raw milk. Journal of Food Protection. 69, 2161-2167.

DEWAAL, C.S., ROBERTS, C. and CATELLA, C. 2012. Outbreak Alert! 19992008. In: Center for Science in the Public Interest.

DURACK, E., ALONSO-GOMEZ, M. and WILKINSON, M.G. 2008. Salt: A Review of its Role in Food Science and Public Health. Current Nutrition \& Food Science. 4, 290-297.

FERNANDES, R. (ed.) 2009. Microbiology Handbook: Dairy Products. Leatherhead Publishing, Randalls Road, Leatherhead, Surrey KT22 7RY, UK.

FERRANTE, D., APRO, N., FERREIRA, V., VIRGOLINI, M., AGUILAR, V., SOSA, M., PEREL, P. and CASAS, J. 2011. Feasibility of salt reduction in processed foods in Argentina. Revista Panamericana de Salud Publica/Pan American Journal of Public Health. 29, 69-75.

FIELDS, L.E., BURT, V.L., CUTLER, J.A., HUGHES, J., ROCCELLA, E.J. and SORLIE, P. 2004. The Burden of Adult Hypertension in the United States 1999 to 2000: A Rising Tide. American Heart Association. 44, 398-404.

FLEMING, D.W., COCHI, S.L., MACDONALD, K.L., BRONDUM, J., HAYES, P.S., PLIKAYTIS, B.D., HOLMES, M.B., AUDURIER, A., BROOME, C.V. and REINGOLD, A.L. 1985. Pasteurized Milk as a Vehicle of Infection in an Outbreak of Listeriosis. New England Journal of Medicine. 312, 404407. 
FRETZ, R., SAGEL, U., RUPPITSCH, W., PIETZKA, A.T., STOGER, A., HUHULESCU, S., HEUBERGER, S., PICHLER, J., MUCH, P., PFAFF, G., STARK, K., PRAGER, R., FLIEGER, A., FEENSTRA, O. and ALLERBERGER, F. 2010. Listeriosis outbreak caused by acid curd cheese 'Quargel', Austria and Germany 2009. Eurosurveillance. 15, 2-3.

FUQUAY, J.W., FOX, P.F. and MCSWEENEY, P.L.H. 2011. Encyclopedia of Dairy Sciences. Academic Press, Burlington.

GAULIN, C., RAMSAY, D. and BEKAL, S. 2012. Widespread listeriosis outbreak attributable to pasteurized cheese, which led to extensive crosscontamination affecting cheese retailers, Quebec, Canada, 2008. Journal of Food Protection. 75, 71-78.

GIKAS, A., KRITSOTAKIS, E.I., MARAKI, S., ROUMBELAKI, M., BABALIS, D., SCOULICA, E., PANOULIS, C., SALOUSTROS, E., KONTOPODIS, E., SAMONIS, G. and TSELENTIS, Y. 2007. A nosocomial, foodborne outbreak of Salmonella Enterica serovar Enteritidis in a University hospital in Greece: the importance of establishing HACCP systems in hospital catering. Journal of Hospital Infection. 66, 194-196.

GRINSTEAD, D.A. and CUTTER, C.N. 2007. Controlling Listeria monocytogenes in a retail setting. Food Protection Trends. 27, 22-28.

GRUMMER, J., KARALUS, M., ZHANG, K., VICKERS, Z. and SCHOENFUSS, T.C. 2012. Manufacture of reduced-sodium Cheddar-style cheese with mineral salt replacers. Journal of Dairy Science. 95, 2830-2839.

GUINEE, T.P. 2004. Salting and the role of salt in cheese. International Journal of Dairy Technology. 57, 99-109.

GURAYA, R., FRANK, J.F. and HASSAN, A.N. 1998. Effectiveness of salt, pH, and diacetyl as inhibitors for Escherichia coli $\mathrm{O} 157: \mathrm{H} 7$ in dairy foods stored at refrigeration temperatures. Journal of Food Protection. 61, 10981102.

HAMMER, K.A., CARSON, C.F. and RILEY, T.V. 1999. Antimicrobial activity of essential oils and other plant extracts. Journal of Applied Microbiology. 86, 985-990. 
HATZINIKOLAOU, D.G. and MACRIS, B.J. 1995. Factors Regulating Production of Glucose-Oxidase by Aspergillus niger. Enzyme and Microbial Technology. 17, 530-534.

HE, F.J. and MACGREGOR, G.A. 2009. A comprehensive review on salt and health and current experience of worldwide salt reduction programmes. Journal of Human Hypertension. 23, 363-384.

HE, F.J., MARCINIAK, M., VISAGIE, E., MARKANDU, N.D., ANAND, V., DALTON, R.N. and MACGREGOR, G.A. 2009. Effect of Modest Salt Reduction on Blood Pressure, Urinary Albumin, and Pulse Wave Velocity in White, Black, and Asian Mild Hypertensives. Hypertension. 54, 482-488.

HEDBERG, C.W., KORLATH, J.A., DAOUST, J.Y., WHITE, K.E., SCHELL, W.L., MILLER, M.R., CAMERON, D.N., MACDONALD, K.L. and OSTERHOLM, M.T. 1992. A multistate outbreak of Salmonella javiana and Salmonella oranienburg infections due to consumption of contaminated cheese. Jama-Journal of the American Medical Association. 268, 3203-3207.

HOTCHKISS, J.H., WERNER, B.G. and LEE, E.Y.C. 2006. Addition of carbon dioxide to dairy products to improve quality: A comprehensive review. Comprehensive Reviews in Food Science and Food Safety. 5, 158-168.

HUGHEY, V.L. and JOHNSON, E.A. 1987. Antimicrobial Activity of Lysozyme against Bacteria Involved in Food Spoilage and Foodborne Disease. Applied and Environmental Microbiology. 53, 2165-2170.

IBRAHIM, H.R., MATSUZAKI, T. and AOKI, T. 2001. Genetic evidence that antibacterial activity of lysozyme is independent of its catalytic function. Febs Letters. 506, 27-32.

IMLAY, J.A. and LINN, S. 1988. DNA Damage and Oxygen Radical Toxicity. Science. 240, 1302-1309.

INGHAM, S.C., SU, Y.C. and SPANGENBERG, D.S. 2000. Survival of Salmonella typhimurium and Escherichia coli $\mathrm{O} 157: \mathrm{H} 7$ in cheese brines. International Journal of Food Microbiology. 61, 73-79. 
ITO, A., SATO, Y. KUDO, S., NAKAJIMA, H. AND TOBA, T. 2003. The screening of hydrogen peroxide-producing lactic acid bacteria and their application to inactivating psychrotrophic food borne pathogens. Current Microbiology. 47, 231-236.

JACKSON, K.A., BIGGERSTAFF, M., TOBIN-D'ANGELO, M., SWEAT, D., KLOS, R., NOSARI, J., GARRISON, O., BOOTHE, E., SAATHOFFHUBER, L., HAINSTOCK, L. and FAGAN, R.P. 2011. Multistate outbreak of Listeria monocytogenes associated with Mexican-style cheese made from pasteurized milk among pregnant, hispanic women. Journal of Food Protection. 74, 949-953.

JANA, A.H. and MANDAL, P.K. 2011. Manufacturing and Quality of Mozzarella Cheese: A Review. International Journal of Dairy Science. 6, 199-226.

JAY, J.M. 1982. Antimicrobial Properties of Diacetyl. Applied and Environmental Microbiology. 44, 525-532.

JOHNSON, M.E., KAPOOR, R., MCMAHON, D.J., MCCOY, D.R. and NARASIMMON, R.G. 2009. Reduction of sodium and fat levels in natural and processed cheeses: scientific and technological aspects.

Comprehensive Reviews in Food Science and Food Safety. 8, 252-268.

KANG, D.H. and FUNG, D.Y.C. 1999. Effect of diacetyl on controlling Escherichia coli $\mathrm{O} 157: \mathrm{H} 7$ and Salmonella Typhimurium in the presence of starter culture in a laboratory medium and during meat fermentation. Journal of Food Protection. 62, 975-979.

KASRAZADEH, M. and GENIGEORGIS, C. 1995. Potential growth and control of Escherichia coli O157:H7 in soft Hispanic type cheese. International Journal of Food Microbiology. 25, 289-300.

KATSIARI, M.C., ALICHANIDIS, E., VOUTSINAS, L.P. and ROUSSIS, I.G. 2000a. Proteolysis in reduced sodium Feta cheese made by partial substitution of $\mathrm{NaCl}$ by KCl. International Dairy Journal. 10, 635-646.

KATSIARI, M.C., ALICHANIDIS, E., VOUTSINAS, L.P. and ROUSSIS, I.G. 2001a. Proteolysis in reduced sodium Kefalograviera cheese made by partial replacement of $\mathrm{NaCl}$ with $\mathrm{KCl}$. Food Chemistry. 73, 31-43. 
KATSIARI, M.C., VOUTSINAS, L.P., ALICHANIDIS, E. and ROUSSIS, I.G. 1997. Reduction of sodium content in Feta cheese by partial substitution of $\mathrm{NaCl}$ by KCl. International Dairy Journal. 7, 465-472.

KATSIARI, M.C., VOUTSINAS, L.P., ALICHANIDIS, E. and ROUSSIS, I.G. 2000b. Lipolysis in reduced sodium Feta cheese made by partial substitution of $\mathrm{NaCl}$ by KCl. International Dairy Journal. 10, 369-373.

KATSIARI, M.C., VOUTSINAS, L.P., ALICHANIDIS, E. and ROUSSIS, I.G. 2001b. Lipolysis in reduced sodium Kefalograviera cheese made by partial replacement of $\mathrm{NaCl}$ with $\mathrm{KCl}$. Food Chemistry. 72, 193-197.

KOCH, J., DWORAK, R., PRAGER, R., BECKER, B., BROCKMANN, S., WICKE, A., WICHMANN-SCHAUER, H., HOF, H., WERBER, D. and STARK, K. 2010. Large Listeriosis Outbreak Linked to Cheese Made from Pasteurized Milk, Germany, 2006-2007. Foodborne Pathogens and Disease. 7, 1581-1584.

KORNACKI, J.L. 2010. Detecting Sources of Listeria monocytogenes in the Ready-To-Eat Food Processing Environment.

KORNITZER, M., DRAMAIX, M. and DE BACKER, G. 1999. Epidemiology of Risk Factors for Hypertension: Implication for Prevention and Therapy. Drugs. 57, 695-712.

KOUSTA, M., MATARAGAS, M., SKANDAMIS, P. and DROSINOS, E.H. 2010. Prevalence and sources of cheese contamination with pathogens at farm and processing levels. Food Control. 21, 805-815.

KUNG, H.C., HOYERT, D.L., XU, J.Q. and MURPHY, S.L. 2008. Deaths: final data for 2005. National Vital Statistics Reports. 56.

KUSSENDRAGER, K.D. and VAN HOOIJDONK, A.C.M. 2000. Lactoperoxidase: physico-chemical properties, occurrence, mechanism of action and applications. British Journal of Nutrition. 84, S19-S25.

LANCIOTTI, R., PATRIGNANI, F., BAGNOLINI, F., GUERZONI, M.E. and GARDINI, F. 2003. Evaluation of diacetyl antimicrobial activity against 
Escherichia coli, Listeria monocytogenes and Staphylococcus aureus. Food Microbiology. 20, 537-543.

LARSON, A., JOHNSON, E.A. and NELSON, J.H. 1993. Behavior of Listeria monocytogenes and Salmonella heidelberg in rennet whey containing added sodium and/or potassium chloride. Journal of Food Protection. 56, 385-389.

LARSON, A.E., JOHNSON, E.A. and NELSON, J.H. 1999. Survival of Listeria monocytogenes in commercial cheese brines. Journal of Dairy Science. $82,1860-1868$.

LEGGETT, L.N., TOMASULA, P.M., VAN HEKKEN, D.L., PORTO-FETT, A.C.S., SHOYER, B., RENYE, J.A., LUCHANSKY, J.B. and FARKYE, N. 2012. Effect of storage at 4 and $10 \mathrm{C}$ on the growth of Listeria monocytogenes in and on queso franco. Journal of Food Safety. 32, 236-245.

LEISTNER, L. and GORRIS, L.G.M. 1995. Food preservation by hurdle technology. Trends in Food Science \& Technology. 6, 41-46.

LITTLE, C.L. and KNOCHEL, S. 1994. Growth and survival of Yersinia enterocolitica, Salmonella and Bacillus cereus in brie stored at $4^{\circ} \mathrm{C}, 8^{\circ} \mathrm{C}$ and $20^{\circ} \mathrm{C}$. International Journal of Food Microbiology. 24, 137-145.

MACDONALD, P.D.M., WHITWAM, R.E., BOGGS, J.D., MACCORMACK, J.N., ANDERSON, K.L., REARDON, J.W., SAAH, J.R., GRAVES, L.M., HUNTER, S.B. and SOBEL, J. 2005. Outbreak of listeriosis among Mexican immigrants as a result of consumption of illicitly produced Mexican-Style cheese. Clinical Infectious Diseases. 40, 677-682.

MAHER, M.M., JORDAN, K.N., UPTON, M.E. and COFFEY, A. 2001. Growth and survival of $E$. coli $\mathrm{O} 157: \mathrm{H} 7$ during the manufacture and ripening of a smear-ripened cheese produced from raw milk. Journal of Applied Microbiology. 90, 201-207.

MAKINO, S.I., KAWAMOTO, K., TAKESHI, K., OKADA, Y., YAMASAKI, M., YAMAMOTO, S. and IGIMI, S. 2005. An outbreak of food-borne listeriosis due to cheese in Japan, during 2001. International Journal of Food Microbiology. 104, 189-196. 
MASSACHALCK, B. and MICHIELS, C.W. (2003). Antimicrobial Properties of Lysozyme in Relation to Foodborne Vegetative Bacteria. Critical Reviews in Microbiology. 29(3), 191-214.

MCMAHON, D.J. 2010. Issues with lower fat and lower salt cheeses. Australian Journal of Dairy Technology. 65, 200-205.

MEYRAND, A., BOUTRAND-LOEI, S., RAY-GUENIOT, S., MAZUY, C., GASPARD, C.E., JAUBERT, G., PERRIN, G., LAPEYRE, C. and VERNOZY-ROZAND, C. 1998. Growth and enterotoxin production of Staphylococcus aureus during the manufacture and ripening of Camembert-type cheeses from raw goats' milk. Journal of Applied Microbiology. 85, 537-544.

MIJAN, M.A., HAQUE, M.A., HABIB, M.A. and WADUD, M.A. 2010. Evaluation of quality of mozzarella cheese. Bangladesh Veterinarian. 27, 36-42.

MOHAN, S. and CAMPBELL, N.R.C. 2009. Salt and high blood pressure. Clinical Science. 117, 1-11.

MONTVILLE, T.J. and CHIKINDAS, M.L. 2007. Biopreservation of Foods. In: Food Microbiology: Fundamentals and Frontiers, (M.P. Doyle and L.R. Beuchat, eds.) pp. 747-764, ASM Press, Washington, D.C.

NUNEZ, M., BAUTISTA, L., MEDINA, M. and GAYA, P. 1988. Staphylococcus aureus, Thermostable Nuclease and Staphylococcal Enterotoxins in Raw Ewes Machego Cheese. Journal of Applied Bacteriology. 65, 29-34.

OLASUPO, N.A., FITZGERALD, D.J., GASSON, M.J. and NARBAD, A. 2003. Activity of Natural Antimicrobial Compounds against Escherichia coli and Salmonella enterica serovar Typhimurium. Letters in Applied Microbiology. $36,448-451$.

OUSSALAH, M., CAILLET, S., SAUCIER, L. and LACROIX, M. 2007a. Inhibitory effects of selected plant essential oils on the growth of four pathogenic bacteria: E. coli $\mathrm{O} 157$ : H7, Salmonella Typhimurium, Staphylococcus aureus and Listeria monocytogenes. Food Control. 18, 414-420. 
OUSSALAH, M., CAILLET, S., SAUCIER, L. and LACROIX, M. 2007b. Inhibitory effects of selected plant essential oils on the growth of four pathogenic bacteria: E. coli O157:H7, Salmonella typhimurium, Staphylococcus aureus and Listeria monocytogenes. Food Control. 18, 414-420.

RAY, B. and BHUNIA, A. 2008. Fundamental Food Microbiology. CRC Press, Boca Raton, FL.

REIJ, M.W. and AANTREKKER, E.D.D. 2004. Recontamination as a source of pathogens in processed foods. International Journal of Food Microbiology. 91, 1-11.

REITSMA, C.J. and HENNING, D.R. 1996. Survival of enterohemorrhagic Escherichia coli $\mathrm{O} 157: \mathrm{H} 7$ during the manufacture and curing of cheddar cheese. Journal of Food Protection. 59, 460-464.

RICKE, S.C. 2003. Perspectives on the use of organic acids and short chain fatty acids as antimicrobials. Poultry Science. 82, 632-639.

RODRIGUEZ, E., CALZADA, J., ARQUES, J.L., RODRIGUEZ, J.M., NUNEZ, M. and MEDINA, M. 2005. Antimicrobial activity of pediocin-producing Lactococcus lactis on Listeria monocytogenes, Staphylococcus aureus and Escherichia coli $\mathrm{O} 157: \mathrm{H} 7$ in cheese. International Dairy Journal. 15, 51-57.

RODRIGUEZ, E., SEGUER, J., ROCABAYERA, X. and MANRESA, A. 2004. Cellular effects of monohydrochloride of $\mathrm{L}$-arginine, $\mathrm{N}$-alpha-lauroyl ethylester (LAE) on exposure to Salmonella typhimurium and Staphylococcus aureus. Journal of Applied Microbiology. 96, 903-912.

ROGGA, K.J., SAMELIS, J., KAKOURI, A., KATSIARI, M.C., SAVVAIDIS, I.N. and KONTOMINAS, M.G. 2005. Survival of Listeria monocytogenes in Galotyri, a traditional Greek soft acid-curd cheese, stored aerobically at 4degreesC and 12degreesC. International Dairy Journal. 15, 59-67.

ROTHSCHILD, M. 2010. Sally Jackson Cheese Confirmed as Outbreak Source. Food Safety News: Breaking News for Everyone's Consumption. Accesed from: http://www.foodsafetynews.com/2010/12/sally-jackson-cheeseconfirmed-as-outbreak-source/\#.UPLQ5_K_NHY. 
SACKS, F.M., SVETKEY, L.P., VOLLMER, W.M., APPEL, L.J., BRAY, G.A., HARSHA, D., OBARZANEK, E., CONLIN, P.R., MILLER, E.R., III, SIMONS-MORTON, D.G., KARANJA, N. and LIN, P. 2001. Effects on blood pressure of reduced dietary sodium and the Dietary Approaches to Stop Hypertension (DASH) diet. New England Journal of Medicine. 344, 310.

SAMELIS, J., KAKOURI, A., ROGGA, K.J., SAVVAIDIS, I.N. and KONTOMINAS, M.G. 2003. Nisin treatments to control Listeria monocytogenes postprocessing contamination on Anthotyros, a traditional Greek whey cheese, stored at 4degreesC in vacuum packages. Food Microbiology. 20,661669.

SCHLESSER, J.E., GERDES, R., RAVISHANKAR, S., MADSEN, K., MOWBRAY, J. and TEO, A.Y.L. 2006. Survival of a five-strain cocktail of Escherichia coli $\mathrm{O} 157: \mathrm{H} 7$ during the 60-day aging period of cheddar cheese made from unpasteurized milk. Journal of Food Protection. 69, 990-998.

SHRESTHA, S., GRIEDER, J.A., MCMAHON, D.J. and NUMMER, B.A. 2011 a. Survival of Listeria monocytogenes introduced as a post-aging contaminant during storage of low-salt Cheddar cheese at 4, 10, and 21 degrees C. Journal of Dairy Science. 94, 4329-4335.

SHRESTHA, S., GRIEDER, J.A., MCMAHON, D.J. and NUMMER, B.A. 2011 b. Survival of Salmonella serovars Introduced as a Post-Aging Contaminant during Storage of Low-Salt Cheddar Cheese at 4, 10, and 21 degrees C. Journal of Food Science. 76, M616-M621.

SOBRINO-LOPEZ, A. AND MARTIN-BELLOSO, O. (2008). Review: Use of Nisin and other Bacteriocins for Preservation of Dairy Products. International Dairy Journal. 18, 329-343.

SONI, K.A., DESAI, M., OLADUNJOYE, A., SKROBOT, F. and NANNAPANENI, R. 2012. Reduction of Listeria monocytogenes in queso fresco cheese by a combination of listericidal and listeriostatic GRAS antimicrobials. International Journal of Food Microbiology. 155, 82-88.

SONI, K.A., NANNAPANENI, R., SCHILLING, M.W. and JACKSON, V. 2010. Bactericidal activity of lauric arginate in milk and Queso Fresco cheese 
against Listeria monocytogenes cold growth. Journal of Dairy Science. 93, 4518-4525.

SPANO, G., GOFFREDO, E., BENEDUCE, L., TARANTINO, D., DUPUY, A. and MASSA, S. 2003. Fate of Escherichia coli O157: H7 during the manufacture of Mozzarella cheese. Letters in Applied Microbiology. 36, 73-76.

STASZEWSKI, M.V. and JAGUS, R.J. 2008. Natural antimicrobials: effect of Microgard TM and nisin against Listeria innocua in liquid cheese whey. International Dairy Journal. 18, 255-259.

STECCHINI, M.L., SARAIS, I. and DEBERTOLDI, M. 1991. The Influence of Lactobacillus plantarum Culture Inoculation on the Fate of Staphylococcus aureus and Salmonella Typhimurium in Montasio Cheese. International Journal of Food Microbiology. 14, 99-109.

STEVENS, K.A., SHELDON, B.W., KLAPES, N.A. and KLAENHAMMER, T.R. 1991. Nisin treatment for inactivation of Salmonella species and other Gram-negative bacteria. Applied and Environmental Microbiology. 57, 3613-3615.

TAORMINA, P.J. 2010. Implications of Salt and Sodium Reduction on Microbial Food Safety. Critical Reviews in Food Science and Nutrition. 50, 209-227.

TOMPKIN, R.B., SCOTT, V.N., BERNARD, D.T., SVEUM, W.H. and GOMBAS, K.S. 1999. Guidelines to Prevent Post-Processing Contamination from Listeria monocytogenes. Dairy, Food and Environmental Sanitation. 19, 551-562.

UKUKU, D.O. 2004. Effect of hydrogen peroxide treatment on microbial quality and appearance of whole and fresh-cut melons contaminated with Salmonella spp.. International Journal of Food Microbiology. 95, 137-146.

VILLAR, R. and MACEK, M. 1997. Outbreak of Salmonella serotype Typhimurium DT104 in Yakima County, Washington State, 1997., (C.f.D.C.a. Prevention, ed.). 
WAHI, S., BANSAL, S., GHOSH, M. and GANGULI, A. 2006. Growth and Survival of Escherichia coli O157:H7 During Manufacture and Storage of Indian Cheese (Paneer). Foodborne Pathogens and Disease. 3, 184-189.

WELLS, H. and BUZBY, J. 2008. Dietary Assessment of Major Trends in US Food Consumption, 1970-2005. Economic Information Bulletin No. 33. Economic Research Service, U.S. Department of Agriculture.

WHITE, C.H. and CUSTER, E.W. 1976. Survival of Salmonella in cheddar cheese. Journal of Milk and Food Technology. 39, 328-331.

ZAPICO, P., MEDINA, M., GAYA, P. and NUNEZ, M. 1998. Synergistic effect of nisin and the lactoperoxidase system on Listeria monocytogenes in skim milk. International Journal of Food Microbiology. 40, 35-42. 


\section{Appendix: Final Cheese Challenge Tables}

Table A.1 Behavior of Listeria monocytogenes in artificially inoculated formulations of low-moisture part-skim (LMPS) mozzarella cheese made with and without sodium replacement agents and SEA-i F75 after incubation at $4^{\circ}$ and $12^{\circ} \mathrm{C}$ (Trial 1 ).

\begin{tabular}{|c|c|c|c|c|c|c|c|c|c|c|c|c|}
\hline \multirow{3}{*}{ Pull Date } & \multicolumn{12}{|c|}{ L. monocytogenes Count (Log CFU/g) } \\
\hline & \multicolumn{2}{|c|}{ Regular Sodium } & \multicolumn{2}{|c|}{ Low Sodium Untreated } & \multicolumn{2}{|c|}{ Low Sodium Treated } & \multicolumn{2}{|c|}{$\mathrm{NaCl} / \mathrm{KCl}$ Combination } & \multicolumn{2}{|c|}{$\mathrm{NaCl} /$ Alta Combination } & \multicolumn{2}{|c|}{$\mathrm{NaCl} /$ Salona Combination } \\
\hline & $4^{\circ} \mathrm{C}$ & $12^{\circ} \mathrm{C}$ & $4^{\circ} \mathrm{C}$ & $12^{\circ} \mathrm{C}$ & $4^{\circ} \mathrm{C}$ & $12^{\circ} \mathrm{C}$ & $4^{\circ} \mathrm{C}$ & $12^{\circ} \mathrm{C}$ & $4^{\circ} \mathrm{C}$ & $12^{\circ} \mathrm{C}$ & $4^{\circ} \mathrm{C}$ & $12^{\circ} \mathrm{C}$ \\
\hline \multicolumn{13}{|l|}{ Day 0} \\
\hline Replicate 1 & 3.60 & 3.60 & 3.45 & 3.45 & 3.36 & 3.36 & 3.10 & 3.10 & 3.06 & 3.06 & 3.05 & 3.05 \\
\hline Replicate 2 & 3.69 & 3.69 & 3.57 & 3.57 & 3.54 & 3.54 & 3.16 & 3.16 & 3.01 & 3.01 & 3.15 & 3.15 \\
\hline Replicate 3 & 3.59 & 3.59 & 3.64 & 3.64 & 3.13 & 3.13 & 3.46 & 3.46 & 3.04 & 3.04 & 3.25 & 3.25 \\
\hline Average & 3.62 & 3.62 & 3.55 & 3.55 & 3.34 & 3.34 & 3.24 & 3.24 & 3.04 & 3.04 & 3.15 & 3.15 \\
\hline \multicolumn{13}{|l|}{ Day 1} \\
\hline Replicate 1 & 3.01 & 3.29 & 3.26 & 3.71 & 2.93 & 2.97 & 3.19 & 3.13 & 3.58 & 3.45 & 3.29 & 2.95 \\
\hline Replicate 2 & 3.45 & 3.83 & 3.01 & 3.90 & 3.27 & 2.99 & 3.08 & 3.18 & 3.10 & 3.38 & 3.10 & 3.35 \\
\hline Replicate 3 & 3.60 & 3.64 & 3.25 & 3.72 & 3.12 & 3.20 & 3.77 & 3.10 & 3.51 & 3.43 & 3.01 & 2.88 \\
\hline Average & 3.35 & 3.59 & 3.17 & 3.78 & 3.11 & 3.05 & 3.35 & 3.14 & 3.40 & 3.42 & 3.13 & 3.06 \\
\hline \multicolumn{13}{|l|}{ Day 3} \\
\hline Replicate 1 & $\mathrm{NT}^{1}$ & 3.54 & NT & 4.26 & NT & 4.22 & NT & 2.59 & NT & 3.45 & NT & 3.19 \\
\hline Replicate 2 & NT & 3.32 & NT & 4.52 & NT & 4.15 & NT & 2.71 & NT & 3.68 & NT & 3.37 \\
\hline Replicate 3 & NT & 3.59 & NT & 4.05 & NT & 4.61 & NT & 2.69 & NT & 3.44 & NT & 3.67 \\
\hline Average & NT & 3.48 & NT & 4.28 & NT & 4.33 & NT & 2.66 & NT & 3.52 & NT & 3.41 \\
\hline \multicolumn{13}{|l|}{ Day 7} \\
\hline Replicate 1 & 3.19 & 6.31 & 3.63 & 6.14 & 2.62 & 4.28 & 3.04 & 4.89 & 2.60 & 5.50 & 2.94 & 4.52 \\
\hline Replicate 2 & 3.37 & 6.60 & 3.69 & 6.23 & 2.72 & 4.76 & 2.95 & 5.04 & 2.43 & 5.53 & 3.01 & 4.25 \\
\hline Replicate 3 & 3.76 & 6.18 & 3.45 & 5.61 & 3.01 & 4.36 & 2.72 & 4.61 & 1.76 & 5.45 & 2.89 & 4.64 \\
\hline Average & 3.44 & 6.36 & 3.59 & 5.99 & 2.78 & 4.47 & 2.90 & 4.85 & 2.26 & 5.50 & 2.95 & 4.47 \\
\hline \multicolumn{13}{|l|}{ Day 15} \\
\hline Replicate 1 & 5.98 & 6.92 & 5.05 & 6.48 & 4.30 & 6.88 & 3.94 & 6.19 & 5.68 & 6.35 & 5.26 & 7.04 \\
\hline Replicate 2 & 5.78 & 6.96 & 4.91 & 6.45 & 4.38 & 6.31 & 4.68 & 6.06 & 5.66 & 7.28 & 4.33 & 5.69 \\
\hline Replicate 3 & 5.77 & 6.94 & 5.42 & 7.10 & 4.57 & 5.70 & 5.04 & 5.72 & 5.58 & 6.99 & 5.10 & 6.17 \\
\hline Average & 5.84 & 6.94 & 5.13 & 6.67 & 4.42 & 6.30 & 4.55 & 5.99 & 5.64 & 6.87 & 4.90 & 6.30 \\
\hline \multicolumn{13}{|l|}{ Day 35} \\
\hline Replicate 1 & 6.70 & 7.61 & 6.16 & 6.60 & 5.41 & 6.66 & 5.06 & 6.29 & 6.90 & 7.77 & 7.19 & 7.62 \\
\hline Replicate 2 & 6.99 & 7.11 & 6.05 & 7.20 & 5.12 & 6.68 & 4.86 & 6.50 & 6.83 & 7.73 & 6.07 & 7.56 \\
\hline Replicate 3 & 7.24 & 7.55 & 5.89 & 6.76 & 5.56 & 6.95 & 6.21 & 6.72 & 6.19 & 7.40 & 5.30 & 7.79 \\
\hline Average & 6.98 & 7.42 & 6.03 & 6.86 & 5.37 & 6.77 & 5.38 & 6.50 & 6.64 & 7.63 & 6.19 & 7.66 \\
\hline
\end{tabular}


Table A.2 Behavior of $L$. monocytogenes in artificially inoculated formulations of low-moisture partskim (LMPS) mozzarella cheese made with and without sodium replacement agents and SEA-i F75 after incubation at $4^{\circ} \mathrm{C}$ (Trials 2 and 3 ).

\begin{tabular}{|c|c|c|c|c|c|c|}
\hline \multirow[b]{2}{*}{ Pull Date } & \multicolumn{6}{|c|}{ L. monocytogenes Count (Log CFU/g) } \\
\hline & $\begin{array}{l}\text { Regular } \\
\text { Sodium }\end{array}$ & $\begin{array}{l}\text { Low Sodium } \\
\text { Untreated }\end{array}$ & $\begin{array}{l}\text { Low Sodium } \\
\text { Treated }\end{array}$ & $\begin{array}{c}\mathrm{NaCl} / \mathrm{KCl} \\
\text { Combination }\end{array}$ & $\begin{array}{c}\text { NaCl/Alta } 2345 \\
\text { Combination }\end{array}$ & $\begin{array}{l}\mathrm{NaCl} / \text { Salona } \\
\text { Combination }\end{array}$ \\
\hline \multicolumn{7}{|l|}{ Day 0} \\
\hline Replicate 1 & 2.92 & 3.09 & 2.99 & 2.02 & 3.19 & 2.93 \\
\hline Replicate 2 & 3.09 & 3.01 & 3.14 & 2.00 & 2.68 & 2.98 \\
\hline Replicate 3 & 3.09 & 2.96 & 2.84 & 1.48 & 3.00 & 3.09 \\
\hline Replicate 4 & 3.04 & 2.90 & 3.16 & 3.01 & 2.99 & 3.13 \\
\hline Replicate 5 & 3.02 & 3.06 & 2.99 & 3.17 & 2.97 & 3.07 \\
\hline Replicate 6 & 3.04 & 3.00 & 3.06 & 3.06 & 2.85 & 0.70 \\
\hline Average & 3.04 & 3.01 & 3.04 & 2.81 & 2.97 & 2.97 \\
\hline \multicolumn{7}{|l|}{ Day 1} \\
\hline Replicate 1 & 2.81 & 2.98 & 3.05 & 1.60 & 2.79 & 2.76 \\
\hline Replicate 2 & 2.67 & 2.94 & 3.14 & 2.00 & 2.82 & 2.88 \\
\hline Replicate 3 & 2.92 & 2.90 & 2.97 & 1.48 & 2.68 & 3.05 \\
\hline Replicate 4 & 2.76 & 3.12 & 2.92 & 2.83 & 2.19 & 2.89 \\
\hline Replicate 5 & 2.90 & 2.71 & 2.80 & 2.76 & 2.37 & 2.70 \\
\hline Replicate 6 & 2.94 & 2.87 & 2.78 & 2.55 & 2.51 & 2.88 \\
\hline Average & 2.84 & 2.94 & 2.96 & 2.48 & 2.61 & 2.88 \\
\hline \multicolumn{7}{|l|}{ Day 7} \\
\hline Replicate 1 & 2.94 & 3.38 & 2.70 & 0.70 & 1.65 & 2.10 \\
\hline Replicate 2 & 2.69 & 2.93 & 2.75 & 1.60 & 2.16 & 2.81 \\
\hline Replicate 3 & 2.92 & 2.74 & 2.69 & 1.54 & 1.78 & 2.19 \\
\hline Replicate 4 & 2.41 & 2.22 & $<1$ & 1.93 & 1.60 & 1.70 \\
\hline Replicate 5 & 2.35 & 2.06 & 1.61 & 1.48 & 1.40 & 1.40 \\
\hline Replicate 6 & 2.56 & 2.08 & 1.88 & 2.15 & 1.40 & 1.18 \\
\hline Average & 2.70 & 2.85 & 2.45 & 1.75 & 1.75 & 2.23 \\
\hline \multicolumn{7}{|l|}{ Day 15} \\
\hline Replicate 1 & 2.81 & 2.67 & 2.83 & $<1$ & 2.41 & 2.53 \\
\hline Replicate 2 & 2.74 & 2.62 & 2.79 & $<1$ & 2.13 & 2.51 \\
\hline Replicate 3 & 2.69 & 2.77 & 2.77 & $<1$ & 2.08 & 2.53 \\
\hline Replicate 4 & 2.43 & 2.35 & 2.11 & 2.02 & 1.00 & 1.54 \\
\hline Replicate 5 & 2.44 & 2.10 & 2.08 & 1.40 & 0.70 & 1.95 \\
\hline Replicate 6 & 2.23 & 2.23 & 2.36 & 1.88 & $<1$ & 1.81 \\
\hline Average & 2.60 & 2.52 & 2.60 & 1.53 & 1.95 & 2.30 \\
\hline
\end{tabular}


Table A.3 Behavior of $L$. monocytogenes in artificially inoculated formulations of low-moisture partskim (LMPS) mozzarella cheese made with and without sodium replacement agents and SEA-i F75 after incubation at $12^{\circ}$ (Trials 2 and 3 ).

\begin{tabular}{|c|c|c|c|c|c|c|}
\hline \multirow[b]{2}{*}{ Pull Date } & \multicolumn{6}{|c|}{ L. monocytogenes Counts (Log CFU/g) } \\
\hline & $\begin{array}{l}\text { Regular } \\
\text { Sodium }\end{array}$ & $\begin{array}{l}\text { Low Sodium } \\
\text { Untreated }\end{array}$ & $\begin{array}{l}\text { Low Sodium } \\
\text { Treated }\end{array}$ & $\begin{array}{c}\mathrm{NaCl} / \mathrm{KCl} \\
\text { Combination }\end{array}$ & $\begin{array}{l}\text { NaCl/Alta } 2345 \\
\text { Combination }\end{array}$ & $\begin{array}{l}\mathrm{NaCl} / \text { Salona } \\
\text { Combination }\end{array}$ \\
\hline \multicolumn{7}{|l|}{ Day 0} \\
\hline Replicate 1 & 2.92 & 3.09 & 2.99 & 2.02 & 3.19 & 2.93 \\
\hline Replicate 2 & 3.09 & 3.01 & 3.14 & 2.00 & 2.68 & 2.98 \\
\hline Replicate 3 & 3.09 & 2.96 & 2.84 & 1.48 & 3.00 & 3.09 \\
\hline Replicate 4 & 3.04 & 2.90 & 3.16 & 3.01 & 2.99 & 3.13 \\
\hline Replicate 5 & 3.02 & 3.06 & 2.99 & 3.17 & 2.97 & 3.07 \\
\hline Replicate 6 & 3.04 & 3.00 & 3.06 & 3.06 & 2.85 & 0.70 \\
\hline Average & 3.04 & 3.01 & 3.04 & 2.81 & 2.97 & 2.97 \\
\hline \multicolumn{7}{|l|}{ Day 1} \\
\hline Replicate 1 & 3.04 & 3.10 & 3.04 & 2.06 & 2.64 & 2.78 \\
\hline Replicate 2 & 2.89 & 2.85 & 2.45 & 2.00 & 2.55 & 2.54 \\
\hline Replicate 3 & 3.16 & 2.96 & 2.82 & 2.18 & 2.55 & 2.62 \\
\hline Replicate 4 & 2.62 & 2.60 & 2.60 & 1.40 & 2.27 & 2.79 \\
\hline Replicate 5 & 2.72 & 2.47 & 2.60 & 2.82 & 1.98 & 2.62 \\
\hline Replicate 6 & 2.84 & 2.65 & 2.82 & 2.80 & 2.24 & 2.54 \\
\hline Average & 2.92 & 2.83 & 2.76 & 2.45 & 2.43 & 2.66 \\
\hline \multicolumn{7}{|l|}{ Day 3} \\
\hline Replicate 1 & 2.62 & 2.15 & 1.60 & 1.54 & 1.85 & 2.89 \\
\hline Replicate 2 & 2.36 & 2.51 & 2.35 & 1.40 & 1.98 & 2.77 \\
\hline Replicate 3 & 2.61 & 2.54 & 2.44 & 1.00 & 1.54 & 2.62 \\
\hline Replicate 4 & 3.07 & 3.50 & 3.26 & 2.55 & 2.54 & 2.82 \\
\hline Replicate 5 & 2.90 & 2.59 & 2.87 & 2.80 & 2.77 & 3.00 \\
\hline Replicate 6 & 2.94 & 2.95 & 2.69 & 1.74 & 2.82 & 3.07 \\
\hline Average & 2.81 & 2.94 & 2.78 & 2.27 & 2.48 & 2.89 \\
\hline \multicolumn{7}{|l|}{ Day 7} \\
\hline Replicate 1 & 3.59 & 3.18 & 2.71 & 2.11 & 2.22 & 2.39 \\
\hline Replicate 2 & 2.87 & 3.13 & 2.76 & 1.95 & 1.70 & 2.55 \\
\hline Replicate 3 & 2.82 & 3.21 & 2.59 & 0.70 & 1.74 & 2.62 \\
\hline Replicate 4 & 2.94 & 3.35 & 1.54 & 1.48 & 1.40 & 1.48 \\
\hline Replicate 5 & 2.72 & 3.49 & 1.60 & 1.00 & $<1$ & 1.54 \\
\hline Replicate 6 & 2.18 & 3.95 & 1.65 & 0.70 & 1.18 & 1.40 \\
\hline Average & 3.06 & 3.50 & 2.42 & 1.65 & 1.71 & 2.28 \\
\hline \multicolumn{7}{|l|}{ Day 15} \\
\hline Replicate 1 & 2.77 & 2.59 & 2.72 & $<1$ & 1.98 & 2.00 \\
\hline Replicate 2 & 3.02 & 2.42 & 2.45 & $<1$ & 1.60 & 2.04 \\
\hline Replicate 3 & 2.90 & 2.33 & 2.83 & $<1$ & 1.74 & 1.48 \\
\hline Replicate 4 & 1.98 & 1.95 & 1.30 & 1.30 & $<1$ & $<1$ \\
\hline Replicate 5 & 1.60 & 1.98 & 1.00 & $<1$ & 0.70 & 0.70 \\
\hline Replicate 6 & 2.89 & 2.34 & 1.98 & 1.54 & 1.18 & 1.18 \\
\hline Average & 2.74 & 2.33 & 2.43 & 0.96 & 1.54 & 1.64 \\
\hline
\end{tabular}


Table A.4 Behavior of Salmonella in artificially inoculated formulations of low-moisture part-skim (LMPS) mozzarella cheese made with and without sodium replacement agents and SEA-i F75 after incubation at $4^{\circ}$ and $12^{\circ} \mathrm{C}$ (Trial 1).

\begin{tabular}{|c|c|c|c|c|c|c|c|c|c|c|c|c|}
\hline \multirow{3}{*}{ Pull Date } & \multicolumn{12}{|c|}{ Salmonella Count (Log CFU/g) } \\
\hline & \multicolumn{2}{|c|}{ Regular Sodium } & \multicolumn{2}{|c|}{ Low Sodium Untreated } & \multicolumn{2}{|c|}{ Low Sodium Treated } & \multicolumn{2}{|c|}{$\mathrm{NaCl} / \mathrm{KCl}$ Combination } & \multicolumn{2}{|c|}{$\mathrm{NaCl} /$ Alta Combination } & \multicolumn{2}{|c|}{$\mathrm{NaCl} /$ Salona Combination } \\
\hline & $4^{\circ} \mathrm{C}$ & $12^{\circ} \mathrm{C}$ & $4^{\circ} \mathrm{C}$ & $12^{\circ} \mathrm{C}$ & $4^{\circ} \mathrm{C}$ & $12^{\circ} \mathrm{C}$ & $4^{\circ} \mathrm{C}$ & $12^{\circ} \mathrm{C}$ & $4^{\circ} \mathrm{C}$ & $12^{\circ} \mathrm{C}$ & $4^{\circ} \mathrm{C}$ & $12^{\circ} \mathrm{C}$ \\
\hline \multicolumn{13}{|l|}{ Day 0} \\
\hline Replicate 1 & 2.13 & 2.13 & 2.45 & 2.45 & 3.30 & 3.30 & 2.04 & 2.04 & 2.65 & 2.65 & 2.02 & 2.02 \\
\hline Replicate 2 & 2.06 & 2.06 & 2.22 & 2.22 & 3.39 & 3.39 & 2.26 & 2.26 & 2.51 & 2.51 & 2.26 & 2.26 \\
\hline Replicate 3 & 2.23 & 2.23 & 2.61 & 2.61 & 3.41 & 3.41 & 2.67 & 2.67 & 2.48 & 2.48 & 2.02 & 2.02 \\
\hline Average & 2.14 & 2.14 & 2.43 & 2.43 & 3.37 & 3.37 & 2.32 & 2.32 & 2.55 & 2.55 & 2.10 & 2.10 \\
\hline \multicolumn{13}{|l|}{ Day 1} \\
\hline Replicate 1 & 1.98 & 1.54 & 1.88 & 1.85 & $<11$ & 0.98 & $<1$ & 1.30 & 1.48 & 1.00 & 2.13 & 1.60 \\
\hline Replicate 2 & 1.93 & 1.78 & 1.00 & 1.70 & 1.48 & 1.00 & 1.40 & 0.98 & 2.30 & 2.53 & 2.28 & 1.39 \\
\hline Replicate 3 & 2.04 & 1.65 & 1.30 & 1.78 & 1.40 & 1.60 & $<1$ & 1.00 & 1.85 & 2.51 & 0.95 & 2.53 \\
\hline Average & 1.98 & 1.66 & 1.39 & 1.77 & 1.26 & 1.19 & 0.97 & 1.09 & 1.87 & 2.01 & 1.79 & 1.84 \\
\hline \multicolumn{13}{|l|}{ Day 3} \\
\hline Replicate 1 & NT & 3.27 & NT & 2.94 & NT & $<1$ & NT & 2.39 & NT & $<1$ & NT & 1.93 \\
\hline Replicate 2 & NT & 3.11 & NT & 3.73 & NT & 0.70 & NT & 2.18 & NT & 2.90 & NT & 3.13 \\
\hline Replicate 3 & NT & 2.74 & NT & 3.25 & NT & 1.30 & NT & 0.98 & NT & 2.77 & NT & 2.79 \\
\hline Average & NT & 3.04 & NT & 3.31 & NT & 0.63 & NT & 1.85 & NT & 2.19 & NT & 2.62 \\
\hline \multicolumn{13}{|l|}{ Day 7} \\
\hline Replicate 1 & 1.30 & 3.56 & 1.16 & 3.55 & 1.18 & 1.48 & $<1$ & 1.16 & 1.48 & 3.51 & 1.00 & 2.64 \\
\hline Replicate 2 & 1.30 & 4.22 & 2.04 & 3.22 & $<1$ & $<1$ & $<1$ & 1.48 & 0.98 & 2.82 & $<1$ & 2.33 \\
\hline Replicate 3 & 1.54 & 3.55 & 1.30 & 3.59 & $<1$ & 1.54 & $<1$ & 0.95 & 0.95 & 3.71 & $<1$ & 1.00 \\
\hline Average & 1.38 & 3.78 & 1.50 & 3.45 & 0.99 & 1.01 & $<1$ & 1.20 & 1.14 & 3.35 & 0.83 & 1.99 \\
\hline \multicolumn{13}{|l|}{ Day 15} \\
\hline Replicate 1 & 1.18 & 2.72 & 2.06 & 3.83 & 0.70 & 2.47 & $<1$ & 1.60 & 2.36 & 4.92 & 0.70 & 5.03 \\
\hline Replicate 2 & 0.00 & 2.06 & 1.85 & 4.23 & 0.70 & 2.22 & $<1$ & 1.40 & 1.90 & 3.84 & $<1$ & 5.69 \\
\hline Replicate 3 & 2.02 & 3.63 & 0.70 & 4.31 & $<1$ & $<1$ & $<1$ & 2.74 & 1.48 & 4.03 & $<1$ & 5.54 \\
\hline Average & 1.07 & 2.80 & 1.53 & 4.12 & 0.77 & 1.90 & $<1$ & 1.91 & 1.91 & 4.26 & 0.83 & 5.42 \\
\hline \multicolumn{13}{|l|}{ Day 35} \\
\hline Replicate 1 & 2.23 & 5.05 & 2.54 & 5.47 & 1.48 & 3.12 & $<1$ & 3.89 & 2.00 & 5.46 & 0.70 & 7.20 \\
\hline Replicate 2 & 1.18 & 4.34 & 2.68 & 4.58 & 0.70 & 3.13 & $<1$ & 2.98 & 4.12 & 5.22 & 1.78 & 6.85 \\
\hline Replicate 3 & 2.67 & 4.25 & 2.11 & 4.76 & 1.30 & 2.97 & $<1$ & 3.35 & 3.10 & 5.16 & 1.54 & 7.33 \\
\hline Average & 2.02 & 4.55 & 2.44 & 4.94 & 1.16 & 3.07 & $<1$ & 3.41 & 3.07 & 5.28 & 1.34 & 7.13 \\
\hline
\end{tabular}


Table A.5 Behavior of Salmonella in artificially inoculated formulations of low-moisture part-skim (LMPS) mozzarella cheese made with and without sodium replacement agents and SEA-i F75 after incubation at $4^{\circ} \mathrm{C}$ (Trials 2 and 3 ).

\begin{tabular}{|c|c|c|c|c|c|c|}
\hline Pull Date & $\begin{array}{l}\text { Regular } \\
\text { Sodium }\end{array}$ & $\begin{array}{l}\text { Low Sodium } \\
\text { Untreated }\end{array}$ & $\begin{array}{l}\text { Low Sodium } \\
\text { Treated }\end{array}$ & $\begin{array}{c}\mathrm{NaCl} / \mathrm{KCl} \\
\text { Combination }\end{array}$ & $\begin{array}{c}\mathrm{NaCl} / \text { Alta } 2345 \\
\text { Combination } \\
\end{array}$ & $\begin{array}{l}\mathrm{NaCl} / \text { Salona } \\
\text { Combination }\end{array}$ \\
\hline \multicolumn{7}{|l|}{ Day 0} \\
\hline Replicate 1 & 2.72 & 2.56 & 1.85 & 1.54 & 1.98 & 2.10 \\
\hline Replicate 2 & 2.56 & 2.66 & 1.81 & 1.54 & 1.81 & 1.78 \\
\hline Replicate 3 & 2.59 & 2.89 & 2.06 & 2.11 & 1.95 & 2.08 \\
\hline Replicate 4 & 2.10 & 2.65 & 2.35 & 2.24 & 1.18 & 2.20 \\
\hline Replicate 5 & 2.38 & 2.86 & 2.23 & 2.69 & 1.93 & 2.22 \\
\hline Replicate 6 & 2.41 & 2.44 & 2.63 & 2.37 & 2.00 & 2.22 \\
\hline Average & 2.50 & 2.71 & 2.25 & 2.26 & 1.88 & 2.12 \\
\hline \multicolumn{7}{|l|}{ Day 1} \\
\hline Replicate 1 & 2.31 & 1.00 & 1.18 & 1.65 & 1.30 & 2.10 \\
\hline Replicate 2 & 0.70 & 1.00 & $<1$ & 1.85 & 1.30 & 2.81 \\
\hline Replicate 3 & 1.81 & $<1$ & $<1$ & 0.70 & $<1$ & 2.19 \\
\hline Replicate 4 & 1.18 & 1.74 & 1.40 & 1.40 & 1.98 & 1.93 \\
\hline Replicate 5 & 1.48 & 2.27 & 2.22 & 0.70 & 0.70 & 1.54 \\
\hline Replicate 6 & 1.70 & 2.49 & 2.45 & 0.95 & 1.48 & 1.30 \\
\hline Average & 1.79 & 1.98 & 1.91 & 1.42 & 1.45 & 2.25 \\
\hline \multicolumn{7}{|l|}{ Day 7} \\
\hline Replicate 1 & $<1$ & $<1$ & 0.70 & $<1$ & $<1$ & $<1$ \\
\hline Replicate 2 & 0.70 & $<1$ & $<1$ & 0.70 & $<1$ & $<1$ \\
\hline Replicate 3 & 1.18 & $<1$ & $<1$ & 0.70 & $<1$ & $<1$ \\
\hline Replicate 4 & 1.54 & 1.81 & 1.81 & $<1$ & $<1$ & 1.65 \\
\hline Replicate 5 & 0.70 & 1.70 & $<1$ & 1.00 & 1.65 & 0.70 \\
\hline Replicate 6 & 1.40 & 1.54 & $<1$ & 0.70 & 0.70 & 1.18 \\
\hline Average & 1.15 & 1.40 & 1.07 & 0.62 & 0.92 & 1.03 \\
\hline \multicolumn{7}{|l|}{ Day 15} \\
\hline Replicate 1 & $<1$ & $<1$ & 1.00 & $<1$ & $<1$ & $<1$ \\
\hline Replicate 2 & $<1$ & $<1$ & $<1$ & $<1$ & $<1$ & $<1$ \\
\hline Replicate 3 & $<1$ & $<1$ & $<1$ & $<1$ & $<1$ & $<1$ \\
\hline Replicate 4 & $<1$ & 1.18 & $<1$ & $<1$ & $<1$ & $<1$ \\
\hline Replicate 5 & 1.30 & 0.70 & $<1$ & $<1$ & $<1$ & $<1$ \\
\hline Replicate 6 & 1.00 & 0.70 & $<1$ & $<1$ & $<1$ & $<1$ \\
\hline Average & 0.70 & 0.62 & 0.22 & $<1$ & $<1$ & $<1$ \\
\hline
\end{tabular}


Table A.6 Behavior of Salmonella in artificially inoculated formulations of low-moisture part-skim (LMPS) mozzarella cheese made with and without sodium replacement agents and SEA-i F75 after incubation at $12^{\circ} \mathrm{C}$ (Trials 2 and 3 ).

\begin{tabular}{|c|c|c|c|c|c|c|}
\hline Pull Date & $\begin{array}{l}\text { Regular } \\
\text { Sodium }\end{array}$ & $\begin{array}{l}\text { Low Sodium } \\
\text { Untreated }\end{array}$ & $\begin{array}{l}\text { Low Sodium } \\
\text { Treated } \\
\end{array}$ & $\begin{array}{c}\mathrm{NaCl} / \mathrm{KCl} \\
\text { Combination }\end{array}$ & $\begin{array}{c}\text { NaCl/Alta } 2345 \\
\text { Combination }\end{array}$ & $\begin{array}{l}\mathrm{NaCl} / \text { Salona } \\
\text { Combination }\end{array}$ \\
\hline \multicolumn{7}{|l|}{ Day 0} \\
\hline Replicate 1 & 2.72 & 2.56 & 1.85 & 1.54 & 1.98 & 2.10 \\
\hline Replicate 2 & 2.56 & 2.66 & 1.81 & 1.54 & 1.81 & 1.78 \\
\hline Replicate 3 & 2.59 & 2.89 & 2.06 & 2.11 & 1.95 & 2.08 \\
\hline Replicate 4 & 2.10 & 2.65 & 2.35 & 2.24 & 1.18 & 2.20 \\
\hline Replicate 5 & 2.38 & 2.86 & 2.23 & 2.69 & 1.93 & 2.22 \\
\hline Replicate 6 & 2.41 & 2.44 & 2.63 & 2.37 & 2.00 & 2.22 \\
\hline Average & 2.50 & 2.71 & 2.25 & 2.26 & 1.88 & 2.12 \\
\hline \multicolumn{7}{|l|}{ Day 1} \\
\hline Replicate 1 & $<1$ & 1.30 & 1.30 & 1.78 & 0.70 & $<1$ \\
\hline Replicate 2 & 0.70 & $<1$ & 1.40 & 0.70 & 1.30 & 1.00 \\
\hline Replicate 3 & 1.30 & 0.70 & 1.48 & 1.18 & $<1$ & $<1$ \\
\hline Replicate 4 & 2.30 & 2.30 & 1.18 & 2.04 & $<1$ & 1.74 \\
\hline Replicate 5 & 2.10 & 2.24 & 1.54 & 1.81 & $<1$ & 1.40 \\
\hline Replicate 6 & 2.34 & 2.42 & 1.74 & 1.48 & 1.65 & 1.78 \\
\hline Average & 1.98 & 2.04 & 1.48 & 1.68 & 1.07 & 1.40 \\
\hline \multicolumn{7}{|l|}{ Day 3} \\
\hline Replicate 1 & 2.08 & 1.93 & 1.93 & 1.88 & $<1$ & 2.39 \\
\hline Replicate 2 & 1.74 & 2.16 & 2.16 & 1.40 & 1.40 & 2.55 \\
\hline Replicate 3 & 1.93 & 2.06 & 2.06 & 0.70 & 0.70 & 2.62 \\
\hline Replicate 4 & 3.10 & 2.89 & 2.36 & 2.11 & $<1$ & 1.93 \\
\hline Replicate 5 & 3.00 & 2.72 & 2.40 & 1.78 & 2.23 & 2.34 \\
\hline Replicate 6 & 3.13 & 2.93 & 2.47 & 1.30 & 1.74 & 2.32 \\
\hline Average & 2.49 & 2.45 & 2.27 & 1.72 & 1.75 & 2.41 \\
\hline \multicolumn{7}{|l|}{ Day 7} \\
\hline Replicate 1 & 1.00 & 0.70 & $<1$ & $<1$ & $<1$ & $<1$ \\
\hline Replicate 2 & $<1$ & 1.48 & 1.18 & $<1$ & 1.00 & $<1$ \\
\hline Replicate 3 & 1.00 & $<1$ & $<1$ & 1.00 & 1.18 & $<1$ \\
\hline Replicate 4 & 2.10 & 2.62 & 1.48 & $<1$ & 0.70 & 1.65 \\
\hline Replicate 5 & 2.19 & 1.00 & 1.00 & 0.70 & 1.48 & 1.30 \\
\hline Replicate 6 & 2.23 & 1.40 & 1.65 & 0.70 & 1.00 & 1.65 \\
\hline Average & 1.89 & 1.91 & 1.22 & 0.52 & 1.07 & 1.26 \\
\hline \multicolumn{7}{|l|}{ Day 15} \\
\hline Replicate 1 & 0.70 & $<1$ & $<1$ & $<1$ & $<1$ & $<1$ \\
\hline Replicate 2 & $<1$ & $<1$ & 1.18 & $<1$ & $<1$ & $<1$ \\
\hline Replicate 3 & $<1$ & $<1$ & $<1$ & $<1$ & $<1$ & $<1$ \\
\hline Replicate 4 & 1.88 & $<1$ & $<1$ & $<1$ & $<1$ & $<1$ \\
\hline Replicate 5 & 1.65 & $<1$ & $<1$ & $<1$ & $<1$ & $<1$ \\
\hline Replicate 6 & $<1$ & $<1$ & $<1$ & $<1$ & $<1$ & $<1$ \\
\hline Average & 1.32 & $<1$ & 0.40 & $<1$ & $<1$ & $<1$ \\
\hline
\end{tabular}


Table A.7 Behavior of E. coli 0157:H7 in artificially inoculated formulations of low-moisture part-skim (LMPS) mozzarella cheese made with and without sodium replacement agents and SEA-i F75 after incubation at $4^{\circ}$ and $12^{\circ} \mathrm{C}$ (Trial 1).

\begin{tabular}{|c|c|c|c|c|c|c|c|c|c|c|c|c|}
\hline \multirow{3}{*}{ Pull Date } & \multicolumn{12}{|c|}{ E. coli 0157:H7 Count (Log CFU/g) } \\
\hline & \multicolumn{2}{|c|}{ Regular Sodium } & \multicolumn{2}{|c|}{ Low Sodium Untreated } & \multicolumn{2}{|c|}{ Low Sodium Treated } & \multicolumn{2}{|c|}{$\mathrm{NaCl} / \mathrm{KCl}$ Combination } & \multicolumn{2}{|c|}{$\mathrm{NaCl} /$ Alta Combination } & \multicolumn{2}{|c|}{$\mathrm{NaCl} /$ Salona Combination } \\
\hline & $4^{\circ} \mathrm{C}$ & $12^{\circ} \mathrm{C}$ & $4^{\circ} \mathrm{C}$ & $12^{\circ} \mathrm{C}$ & $4^{\circ} \mathrm{C}$ & $12^{\circ} \mathrm{C}$ & $4^{\circ} \mathrm{C}$ & $12^{\circ} \mathrm{C}$ & $4^{\circ} \mathrm{C}$ & $12^{\circ} \mathrm{C}$ & $4^{\circ} \mathrm{C}$ & $12^{\circ} \mathrm{C}$ \\
\hline \multicolumn{13}{|l|}{ Day 0} \\
\hline Replicate 1 & 3.27 & 3.27 & 3.53 & 3.53 & 2.26 & 2.26 & 3.45 & 3.45 & 3.22 & 3.22 & 2.68 & 2.68 \\
\hline Replicate 2 & 3.51 & 3.51 & 3.67 & 3.67 & 2.11 & 2.11 & 3.45 & 3.45 & 3.10 & 3.10 & 2.45 & 2.45 \\
\hline Replicate 3 & 3.72 & 3.72 & 3.47 & 3.47 & 2.06 & 2.06 & 3.64 & 3.64 & 3.01 & 3.01 & 2.98 & 2.98 \\
\hline Average & 3.50 & 3.50 & 3.56 & 3.56 & 2.14 & 2.14 & 3.51 & 3.51 & 3.11 & 3.11 & 2.70 & 2.70 \\
\hline \multicolumn{13}{|l|}{ Day 1} \\
\hline Replicate 1 & 2.96 & 2.91 & 2.65 & 3.37 & 1.85 & 2.44 & 2.81 & 2.98 & 2.68 & 3.26 & 3.15 & 2.93 \\
\hline Replicate 2 & 3.13 & 2.89 & 3.00 & 3.48 & 2.27 & 2.71 & 2.54 & 2.60 & 2.99 & 3.33 & 3.01 & 3.17 \\
\hline Replicate 3 & 2.94 & 3.08 & 3.05 & 3.81 & 1.00 & 1.54 & 2.54 & 2.81 & 2.92 & 3.68 & 2.69 & 2.87 \\
\hline Average & 3.01 & 2.96 & 2.90 & 3.55 & 1.70 & 2.23 & 2.63 & 2.80 & 2.86 & 3.43 & 2.95 & 2.99 \\
\hline \multicolumn{13}{|l|}{ Day 3} \\
\hline Replicate 1 & NT & 3.46 & NT & 4.15 & NT & 2.45 & NT & 2.98 & NT & 3.96 & NT & 2.54 \\
\hline Replicate 2 & NT & 3.05 & NT & 3.87 & NT & 3.01 & NT & 2.64 & NT & 3.82 & NT & 2.74 \\
\hline Replicate 3 & NT & 3.75 & NT & 4.06 & NT & 1.81 & NT & 2.63 & NT & 3.98 & NT & 2.50 \\
\hline Average & NT & 3.42 & NT & 4.03 & NT & 2.42 & NT & 2.75 & NT & 3.92 & NT & 2.59 \\
\hline \multicolumn{13}{|l|}{ Day 7} \\
\hline Replicate 1 & 1.95 & 4.54 & 2.60 & 4.59 & $<11$ & 3.15 & 1.69 & 3.49 & 1.48 & 4.95 & 0.70 & 4.84 \\
\hline Replicate 2 & 1.78 & 4.30 & 2.48 & 4.59 & $<1$ & 2.81 & 0.98 & 3.68 & 0.98 & 5.32 & 0.70 & 4.42 \\
\hline Replicate 3 & 1.98 & 4.25 & 2.19 & 4.72 & 1.74 & 3.56 & 2.78 & 3.21 & 1.48 & 4.45 & 0.70 & 4.68 \\
\hline Average & 1.90 & 4.36 & 2.42 & 4.63 & 1.18 & 3.17 & 1.82 & 3.46 & 1.31 & 4.91 & 0.70 & 4.65 \\
\hline \multicolumn{13}{|l|}{ Day 15} \\
\hline Replicate 1 & 3.81 & 4.42 & 3.57 & 6.10 & 0.70 & 5.18 & 2.63 & 4.11 & 4.61 & 6.95 & 1.40 & 7.04 \\
\hline Replicate 2 & 1.30 & 4.57 & 3.95 & 5.48 & 1.70 & 4.05 & 1.00 & 4.11 & 5.12 & 6.95 & 1.98 & 6.33 \\
\hline Replicate 3 & 1.54 & 4.10 & 3.60 & 5.88 & 0.70 & 5.25 & 2.59 & 5.00 & 2.35 & 6.33 & 1.48 & 5.59 \\
\hline Average & 2.22 & 4.37 & 3.71 & 5.82 & 1.03 & 4.82 & 2.07 & 4.40 & 4.03 & 6.74 & 1.62 & 6.32 \\
\hline \multicolumn{13}{|l|}{ Day 35} \\
\hline Replicate 1 & 4.18 & 3.00 & 4.42 & 7.25 & 1.70 & 5.14 & 0.70 & 5.17 & 2.00 & 6.29 & 3.77 & 6.45 \\
\hline Replicate 2 & 3.36 & 3.30 & 3.70 & 7.09 & 1.70 & 5.13 & $<1$ & 5.98 & 4.12 & 6.53 & 4.30 & 6.70 \\
\hline Replicate 3 & 3.65 & 4.77 & 3.57 & 6.59 & 1.40 & 5.83 & 2.47 & 5.94 & 3.10 & 6.46 & 4.20 & 7.77 \\
\hline Average & 3.73 & 3.69 & 3.90 & 6.97 & 1.60 & 5.37 & 1.36 & 5.69 & 3.07 & 6.43 & 4.09 & 6.97 \\
\hline
\end{tabular}


Table A.8 Behavior of E. coli 0157:H7 in artificially inoculated formulations of low-moisture partskim (LMPS) mozzarella cheese made with and without sodium replacement agents and SEA-i F75 after incubation at $4^{\circ} \mathrm{C}$ (Trials 2 and 3 ).

\begin{tabular}{ccccccc}
\hline Pull Date & $\begin{array}{c}\text { Regular } \\
\text { Sodium }\end{array}$ & $\begin{array}{c}\text { Low Sodium } \\
\text { Untreated }\end{array}$ & $\begin{array}{c}\text { Low Sodium } \\
\text { Treated }\end{array}$ & $\begin{array}{c}\text { NaCl/KCl } \\
\text { Combination }\end{array}$ & $\begin{array}{c}\text { NaCl/Alta 2345 } \\
\text { Combination }\end{array}$ & $\begin{array}{c}\text { NaCl/Salona } \\
\text { Combination }\end{array}$ \\
\hline Day 0 & & & & & & \\
Replicate 1 & 2.74 & 2.92 & 2.49 & 2.67 & 2.58 & 2.64 \\
Replicate 2 & 2.64 & 2.89 & 2.56 & 2.81 & 2.55 & 2.77 \\
Replicate 3 & 2.78 & 2.83 & 2.51 & 2.99 & 2.56 & 2.51 \\
Replicate 4 & 2.69 & 2.47 & 2.72 & 2.52 & 2.70 & 2.72 \\
Replicate 5 & 2.91 & 2.80 & 2.82 & 2.66 & 2.76 & 2.65 \\
Replicate 6 & 2.94 & 3.04 & 2.78 & 2.81 & 2.62 & 2.69 \\
Average & 2.80 & 2.86 & 2.66 & 2.77 & 2.64 & 2.67 \\
& & & & & & \\
Day 1 & & & & & & \\
Replicate 1 & 2.50 & 1.78 & 1.30 & 0.70 & $<1$ & 1.85 \\
Replicate 2 & 2.32 & 1.85 & 0.70 & 1.18 & 0.70 & 1.74 \\
Replicate 3 & 2.88 & 1.70 & 1.00 & 1.18 & 1.70 & 1.30 \\
Replicate 4 & 1.95 & 2.15 & 1.65 & 2.34 & 2.30 & 2.04 \\
Replicate 5 & 2.00 & 1.98 & 1.81 & 2.34 & 1.98 & 1.93 \\
Replicate 6 & 2.10 & 2.22 & 1.54 & 2.29 & 2.23 & 1.95 \\
Average & 2.43 & 1.99 & 1.48 & 2.05 & 1.94 & 1.86 \\
Day 7 & & & & & & \\
Replicate 1 & 2.77 & 2.74 & 2.13 & 1.18 & $<1$ & 2.15 \\
Replicate 2 & 2.79 & 2.81 & 1.93 & 1.54 & 1.00 & 2.04 \\
Replicate 3 & 2.95 & 2.61 & 1.60 & 1.78 & 2.08 & 1.98 \\
Replicate 4 & 2.57 & 2.60 & 1.95 & 2.02 & 1.93 & 1.48 \\
Replicate 5 & 2.02 & 2.29 & 1.95 & 2.04 & 1.81 & 1.85 \\
Replicate 6 & 1.91 & 2.22 & 1.81 & 2.15 & 1.95 & 1.65 \\
Average & 2.65 & 2.59 & 1.93 & 1.89 & 1.79 & 1.91 \\
Day 15 & & & & & & \\
Replicate 1 & 2.58 & 2.47 & 1.54 & $<1$ & 0.70 & 1.18 \\
Replicate 2 & 1.40 & 2.16 & 1.30 & $<1$ & 0.70 & 1.30 \\
Replicate 3 & 1.65 & 2.47 & 1.70 & $<1$ & 1.93 & \\
Replicate 4 & 1.70 & 2.59 & 0.70 & 2.11 & 1.00 & \\
Replicate 5 & 1.81 & 2.83 & 1.48 & 1.54 & 1.43 & \\
Replicate 6 & 1.70 & 1.85 & 0.70 & 1.18 & & \\
Average & 2.01 & 2.49 & 1.38 & 1.48 & & \\
\hline & & & & & & \\
\hline
\end{tabular}


Table A.9 Behavior of $E$. coli 0157:H7 in artificially inoculated formulations of low-moisture partskim (LMPS) mozzarella cheese made with and without sodium replacement agents and SEA-i F75 after incubation at $12^{\circ} \mathrm{C}$ (Trials 2 and 3 ).

\begin{tabular}{|c|c|c|c|c|c|c|}
\hline Pull Date & $\begin{array}{l}\text { Regular } \\
\text { Sodium }\end{array}$ & $\begin{array}{l}\text { Low Sodium } \\
\text { Untreated }\end{array}$ & $\begin{array}{l}\text { Low Sodium } \\
\text { Treated }\end{array}$ & $\begin{array}{c}\mathrm{NaCl} / \mathrm{KCl} \\
\text { Combination }\end{array}$ & $\begin{array}{c}\text { NaCl/Alta } 2345 \\
\text { Combination }\end{array}$ & $\begin{array}{l}\mathrm{NaCl} / \text { Salona } \\
\text { Combination }\end{array}$ \\
\hline \multicolumn{7}{|l|}{ Day 0} \\
\hline Replicate 1 & 2.74 & 2.92 & 2.49 & 2.67 & 2.58 & 2.64 \\
\hline Replicate 2 & 2.64 & 2.89 & 2.56 & 2.81 & 2.55 & 2.77 \\
\hline Replicate 3 & 2.78 & 2.83 & 2.51 & 2.99 & 2.56 & 2.51 \\
\hline Replicate 4 & 2.69 & 2.47 & 2.72 & 2.52 & 2.70 & 2.72 \\
\hline Replicate 5 & 2.91 & 2.80 & 2.82 & 2.66 & 2.76 & 2.65 \\
\hline Replicate 6 & 2.94 & 3.04 & 2.78 & 2.81 & 2.62 & 2.69 \\
\hline Average & 2.80 & 2.86 & 2.66 & 2.77 & 2.64 & 2.66 \\
\hline \multicolumn{7}{|l|}{ Day 1} \\
\hline Replicate 1 & 1.90 & 2.08 & 1.48 & 2.27 & 2.83 & 1.70 \\
\hline Replicate 2 & 1.00 & 2.11 & 1.60 & 2.39 & 1.98 & 2.10 \\
\hline Replicate 3 & 2.53 & 2.15 & 1.40 & 2.41 & 2.24 & 1.95 \\
\hline Replicate 4 & 2.15 & 1.81 & 1.18 & 1.18 & 1.00 & 2.11 \\
\hline Replicate 5 & 2.29 & 1.54 & 1.54 & 1.54 & 1.40 & 1.74 \\
\hline Replicate 6 & 2.45 & 1.81 & 1.74 & 1.70 & 1.48 & 1.48 \\
\hline Average & 2.24 & 1.97 & 1.52 & 2.12 & 2.23 & 1.90 \\
\hline \multicolumn{7}{|l|}{ Day 3} \\
\hline Replicate 1 & 2.08 & 2.30 & 0.70 & 2.11 & 0.70 & 2.60 \\
\hline Replicate 2 & 1.74 & 1.70 & 1.40 & 2.02 & 1.60 & 1.90 \\
\hline Replicate 3 & 1.93 & 2.69 & 1.48 & 2.47 & 1.65 & 2.33 \\
\hline Replicate 4 & 3.10 & 2.62 & 1.95 & $<1$ & 1.00 & 1.30 \\
\hline Replicate 5 & 3.00 & 2.58 & 2.56 & 1.54 & $<1$ & 1.00 \\
\hline Replicate 6 & 3.13 & 2.45 & 2.35 & 2.18 & $<1$ & $<1$ \\
\hline Average & 2.81 & 2.48 & 2.09 & 2.08 & 1.22 & 2.08 \\
\hline \multicolumn{7}{|l|}{ Day 7} \\
\hline Replicate 1 & 2.79 & 1.65 & 2.43 & 1.70 & 1.40 & 1.54 \\
\hline Replicate 2 & 3.06 & 1.85 & 2.11 & 2.18 & 1.70 & 1.90 \\
\hline Replicate 3 & 3.53 & 1.65 & 1.54 & 2.18 & 1.54 & 2.36 \\
\hline Replicate 4 & 2.13 & 1.95 & 1.74 & $<1$ & 2.04 & 2.02 \\
\hline Replicate 5 & 1.95 & 2.19 & 1.70 & $<$ & 2.13 & 1.85 \\
\hline Replicate 6 & 2.28 & 2.18 & 1.91 & 2.10 & 2.11 & 1.98 \\
\hline Average & 2.97 & 1.97 & 2.00 & 1.90 & 1.91 & 2.01 \\
\hline \multicolumn{7}{|l|}{ Day 15} \\
\hline Replicate 1 & 2.06 & 1.70 & 0.70 & $<1$ & $<1$ & 0.70 \\
\hline Replicate 2 & 2.29 & 1.65 & 1.60 & $<1$ & 1.00 & 1.18 \\
\hline Replicate 3 & 1.95 & 2.29 & $<1$ & $<1$ & 1.48 & 1.65 \\
\hline Replicate 4 & 1.70 & 2.67 & 2.04 & 1.30 & 1.30 & 1.40 \\
\hline Replicate 5 & 1.54 & 2.32 & 1.65 & $<1$ & 1.00 & 0.70 \\
\hline Replicate 6 & 2.33 & 1.85 & 2.20 & 1.54 & 1.18 & $<1$ \\
\hline Average & 2.07 & 2.24 & 1.78 & 0.96 & 1.15 & 1.20 \\
\hline
\end{tabular}

